\title{
Decomposition Studies of Tetraphenylborate Slurries
}

by

C. L. Crawford

Westinghouse Savannah River Company

Savannah River Site

Aiken, South Carolina 29808

DOE Contract No. DE-AC09-96SR18500

This paper was prepared in connection with work done under the above contract number with the U.S.

Department of Energy. By acceptance of this paper, the publisher and/or recipient acknowledges the U.S. Government's right to retain a nonexclusive, royalty-free license. in and to any copyright covering this paper, along with the right to reproduce and to authorize others to reproduce all or part of the copyrighted paper. 


\section{DISCLAIMER}

Portions of this document may be illegible electronic image products. Images are produced from the best available original document. 


\section{DECONPOSITION STUDIES OF TETRAPAIFNYIBORATIS SLURRIISS (U)}

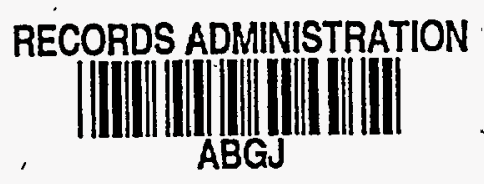

C. I. Crawford

Publication Date: May 6, 1997

Westinghouse Savanuah River Company Savannah Rtver Technical Center

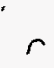




\section{SUMAMRY}

Researchers studied the decomposition of aqueous ( $\mathrm{K}, \mathrm{Na}$ ).TPB slurries in concentrated salt solutions containing. potential catalytic additives between 40 to $70^{\circ} \mathrm{C}$. The following statements sumarize the results.

- Comparison of several measures of NaTPB decomposition indicates that the present simulant recipe does result in reaction similar to that observed previously in Tank 48H. The measures include maximum amounts and rates of production for several decomposition species such as soluble boron and potassium, benzene, phenylboronic acid and phenol.

- Using a simplified kinetic analysis, researchers calculate the activation energy obtained for decomposition of NaTPB in the slurries as about $43 \pm 20 \mathrm{~kJ} / \mathrm{mole}$ in the temperature range of 40 to $70^{\circ} \mathrm{C}$. This value remains lower than that from copper only rates and suggests another catalyst.

- Removing only solid monosodium titanate from the comprehensive recipe had no significant effects on NaTPB. decomposition relative to that observed using the comprehensive recipe at. 55 and $70{ }^{\circ} \mathrm{C}$.

- Removing both solid sludge additives, which contained about $80 \%$ of the total noble metals $\mathrm{Ru}, \mathrm{Pd}$ and $\mathrm{Rh}$ found in the comprehensive recipe, and solid monosodium titanate additives from the comprehensive recipe resulted in decreased NaTPB decomposition rates at $55^{\circ} \mathrm{C}$. Magnitudes of decomposition products were also decreased. The NaTPB decomposition decreased $15 \%$ or less, compared to average soluble boron measurements at $55{ }^{\circ} \mathrm{C}$ from duplicate tests containing the comprehensive recipe.

- Similar comparisons from removing these materials at $70{ }^{\circ} \mathrm{C}$ indicate a more significant decrease in NaTPB decomposition rates and decreased magnitudes of decomposition products. The decrease in NaTPB decomposition reached about 258 compared to soluble boron measurements at $70^{\circ} \mathrm{C}$ from average duplicate tests containing the comprehensive recipe.

- Duplicate slurries tested in the temperature range of 40 to $70{ }^{\circ} \mathrm{C}$ indicate variability of 28 to $25 \%$ and 38 to 178 in measurements of phenol and soluble boron, respectively. This variability comes from relative standard deviations calculated from comparison of phenol and soluble boron concentrations at about 400, 1000 and $1600 \mathrm{hr}$ of testing.

- Measurable amounts of NaTPB solids existed in all slurries tested at 40 and $55^{\circ} \mathrm{C}$ for 1600 hours indicating incomplete decomposition of the initial NaTPB solids. Similar analyses indicate complete decomposition of NaTPB in certain tests at $70^{\circ} \mathrm{C}$.

- Researchers detected insignificant amounts of potassium ion in filtrates of reacted slurries containing all potential catalytic additives at $.40^{\circ} \mathrm{C}$ for 1600 hours, indicating no detectable dissolution of the initial KTPB solids. 
- Analyses showed measurable amounts of potassium from filtrates of reacted slurxies containing all potential catalytic additives at 55 and $70^{\circ} \mathrm{C}$ for 1600 hours, indicating KTPB solids decomposition or dissolution of about $1,920 \mathrm{mg} / \mathrm{L}$ and $14,656 \mathrm{mg} / \mathrm{L}$ KTPB solids, respectively. These levels of KTPB solids correspond to roughly $5 \%$ and 10\%, respectively, of the targeted starting $48,000 \mathrm{mg} / \mathrm{L}$ KTPB solids present initially.

- Preliminary calculations explain the levels of soluble potassium by the temperature dependent equilibrium of the KTPB and NaTPB solids, coupled with the decomposition kinetics of soluble TPB-. at the higher temperatures of 55 and $70^{\circ} \mathrm{C}$.

\section{Becommendations}

- A complete and thorough analysis of various kinetic parameters for the data presented in Tables 1 through 10 of this study should occur. Efforts should analyze the resulting composition data of each test in a comprehensive manner to obtain kinetic data for tetraphenylborate and the intermediates triphenylborane, diphenylborinic acid and phenylboronic acid.

- Researchers should perform rigorous calculations involving the temperature dependent equilibrium of KTPB and NaTPB solids coupled with the decomposition kinetics of soluble TPB to show that the magnitudes of soluble potassium analyzed fall within the expected dissolution of solid KTPB.

\section{INIRODUCTIOA}

The In-Tank' Precipitation (ITP) process started radioactive operation in Tank 48H in August of 1995. High rates of sodium tetraphenylborate (NaTPB) decomposition and benzene generation were encountered approximately 2-3 months after beginning ITP operations. 1,2 Sodium tetraphenylborate exhibits known instability in the presence of copper. 3 Recent work indicates excess sodium tetraphenylborate in Tank 48H is susceptible to decomposition, with the rate strongly influenced by temperature. 4

Preliminary data reported in Ref. 1 (specifically the tests described in -Series 1 and 2 Sealed Stainless-Steel Bottle. Tests on pages 51-59) indicate that aqueous ( $K, N a)$ TPB slurries in concentrated salt solutions can partially decompose on time-scales of several hundred hours in the presence of simulated sludge containing noble metals, monosodium titanate (MST), various soluble metals and organic additives at temperatures of $70^{\circ} \mathrm{C}$. Decomposition of the slurries, contained in airsealed stainless-steel bottles, was evidenced by approximate complete loss of all soluble as well as insoluble NaTPB present in the original $(K, N a)$ TPB slurry. The calculated losses of both TPB and solid NaTPB were based on comparison with total measured soluble boron and benzene yields. The primary decomposition product was benzene. Other products analyzed in the above tests included soluble boron, phenylboronic acid (1PB) and the relatively stable final organic product phenol. 
This report details the decomposition of aqueous ( $K, N a)$ TPB slurries in concentrated salt solutions using a more complete candidate catalyst recipe, extended testing temperatures $\left(40-70^{\circ} \mathrm{C}\right)$ and test durations of . $\sim 1500$ hours (9 weeks). This study uses recently developed High-Pressure Ilquid Chromatography (HRLC) methods for analysis of tetraphenylborate $\left(\mathrm{TPB}^{-}\right)$, triphenylborane (3PB) and diphenylborinic acid (2PB). Ail of the present tests involve non-radioactive simulants and do not include investigations of radiolysis effects. The main objectives of the tests. include: .

- establishing the extent of TPB- decomposition reactions at lower temperatures (i.e., at. 40 and $55^{\circ} \mathrm{C}$ ) than previously tested,

- demonstrating that the catalyst recipe provides an all-inclusive or near-complete set of additives from which statistically designed NaTPB decomposition test's can follow, 5 ,

- verifying this simulant recipe results in a reaction that approximates the current understanding of Tank $48 \mathrm{H}$ behavior in December 1995,6 and

- investigating the effects of both sludge solids and monosodium titanate (MST) solids on tetraphenylborate decomposition. 7

The following sections discuss the results of this study. Appendix A details the overall test design and experimental methods..

\section{RESULTS AND DISCUSSION}

The extent of tetraphenylborate decomposition in the slurries was measured by the.following methods. The slurries and vapor spaces were both analyzed for benzene. Filtrates from the slurries were also analyzed for soluble organic compounds and soluble boron. Tables 1 through 12 contain data sets for all twelve tests. Figures 1 through 14 depict these results.

Figures $i$ to 5 show plots of the total measured benzene versus time. Figures 6 to 14 show plots of soluble organic compounds and soluble boron versus time. Figures 6 through 8 compare average values plotted from duplicate tests at 40 to $70^{\circ} \mathrm{C}$. The plots include two different measures of boron: measured total soluble boron determined from emission spectroscopy and cumulative soluble boron based on the sum of measured $\mathrm{TPB}^{-}, 3 \mathrm{~PB}, 2 \mathrm{~PB}$ and $1 \mathrm{~PB}$..

Benzene Production

complete Catalyst Systems:

Figures 1 to 3 show measured benzene for the duplicate systems tested at 40,55 and $70^{\circ} \mathrm{C}$, respectively with the complete catalyst system present (Table A-2). Benzene data for the $40^{\circ} \mathrm{C}$ duplicate tests appear consistent showing a steady increase with time, reaching maximum values approaching $2,500 \mathrm{mg} / \mathrm{L}$. Benzene data for the 55 and $70^{\circ} \mathrm{C}$ tests show considerable variability, reaching maximum values approaching $6,000 \mathrm{mg} / \mathrm{L}$. Data recorded during these tests included vessel weights before and after incubation periods and gas chromatography (GC) calibration before and after each sampling: The GC calibration data 
indicate a variability of about $6 \%$ or less over the total 1600 hour duration of these tests. Analysis of the vessel weights indicate possible benzene losses during testing. Researchers measured mass. losses on the order of 0.1 to 0.3 grams between successive samplings for some of the tests at the higher temperatures of 55 and $70{ }^{\circ} \mathrm{C}$. These magnitudes of weight loss account for the various decreases in benzene (i.e., about 1000 to $3500 \mathrm{mg} / \mathrm{L}$ ) plotted in Figures 2 and 3 . The observed benzene measurement variability also likely results from nonrepresentative sampling of the slurries.

Incomplete Catalyst systems

Benzene data for additional tests using less complete recipes at 55 to $70{ }^{\circ} \mathrm{C}$ showed roughly the same trends as tests performed at similar temperatures of $55^{\circ}$ to $70^{\circ} \mathrm{C}$. with all additives present. Figure 4 shows benzene data plotted for these tests. These data also reflect benzene losses of about 1000 .to $2000 \mathrm{mg} / \mathrm{L}$ similax to those discussed above. In all tests shown in Figure 4 , the maximum amount of benzene measured reached values in the range of $4,000 \mathrm{mg} / \mathrm{I}_{\mathrm{s}}$ to $6,000 \mathrm{mg} / \mathrm{L}$. Benzene data for the two slurries tested at 55 and $70{ }^{\circ} \mathrm{C}$ with no additives present show little benzene produced (typically $<50 \mathrm{mg} / \mathrm{L}$ ) compared to levels approaching $6,000 \mathrm{mg} / \mathrm{L}$ detected in slurries tested with additives present. Hence, these benzene measurements do not conservatively represent the total benzene produced in these tests, given the observed mass losses and measurement variability resulting from nonrepresentative sampling.

One may also express benzene yields as generation rates. Tables 1 through 12 provide these values, expressed in units of $\mu g /\left(L^{\star} \mathrm{hr}\right)$. The benzene generation rates result from dividing the total benzene measured at a given time by the total number of hours in that time interval from the start of the tests. The range in benzene generation rates generally increases with temperature although much scatter exists in measured benzene levels. The maximum rates ranged from 1700-1900 $\mathrm{gg} /(\mathrm{I} * \mathrm{hr})$ at $40^{\circ} \mathrm{C}, 5500-7000 \mu \mathrm{g} /\left(\mathrm{L}^{*} \mathrm{hr}\right)$ at $55^{\circ} \mathrm{C}$ and $6300-15900 \mu \mathrm{g} /\left(\mathrm{L}^{*} \mathrm{hr}\right)$ at $70^{\circ} \mathrm{C}$.

Tetraphenylborate Decomosition and Soluble Boron Production,

Several trends occurred for the expected increase in the rate of NaTPB decomposition with temperature from 40 to $70^{\circ} \mathrm{C}$. As temperature increases, the rate of loss of soluble TPB increases, the peak concentrations of all boron-containing organic intermediates occurs earlier in time and the rate of boron appeararice, measured as total soluble boron in solution, steadily increases. These trends are shown in Figures 6 through 8 and the data are contained in Tables 1 through 6 . Appearance of soluble boron in the reaction mixtures in amounts greater than the initial soluble TPB - indicates production of phenyl borate intermediates and boric acid either from decomposition of soluble TPB with subsequent dissolution of solid tetraphenylborates or from direct decomposition of the solid. One can measure soluble boron directly by ICP-ES (see Tables 1-12, 'Boron (ICP-ES)') or by HPLC measurements of phenyl borates (see Tables 1-12, 'Boron (from organics)'). These two methods are represented by the equations below.

- Soluble boron (ICP-ES): $=\mathrm{TPB}^{-}+3 \mathrm{~PB}+2 \mathrm{~PB}+1 \mathrm{~PB}+$ Boric Acid

- soluble boron (HPLC): $=\mathrm{TPB}^{-}+3 \mathrm{~PB}+2 \mathrm{~PB}+1 \mathrm{~PB}$ 
Table 13 summarizes the initial rates of NaTPB decomposition calculated from these boron measurements over the first $168 \mathrm{hr}$ of testing. Note that these rates are calculated using only two data points involving measured boron concentrations at 0 and $168 \mathrm{hr}$.' The two different boron rate measurement values agree. reasonably well for each individual test at the lower temperatures (i.e., 40 and $55^{\circ} \mathrm{C}$ ). The data shown in Table 13 for the duplicate systems tested at 40 to $70{ }^{\circ} \mathrm{C}$ with all additives present (see Tests 1 through 6 ) indicate that the soluble boron production rates increase with temperature. Based on. ICP-ES boron data, the average rates increase from about $2.0 \times 10^{-5} \mathrm{~mole} /(\mathrm{L} * \mathrm{hr})$ to $5.5 \times 10^{-5}$ mole/ (L*hr) to $7.8 \times 10^{-5} \mathrm{~mole} /\left(\mathrm{L}^{*} \mathrm{hr}\right)$ for the respective temperatures of 40,55 and $70^{\circ} \mathrm{C}$. Note that the duplicate tests at $55^{\circ} \mathrm{C}$ show rather good precision. However, at $40^{\circ} \mathrm{C}$ and $70^{\circ} \mathrm{C}$ the range of total boron appearance rates show a relatively large variability (i.e., 0.92 to 3.08 $\times 10^{-5} \mathrm{~mole} /\left(L^{*} \mathrm{hr}\right)$ at $55^{\circ} \mathrm{C}$ and 4.8 to $10.8 \times 10^{-5} \mathrm{~mole} /\left(\mathrm{L}^{\star} \mathrm{hr}\right)$ at $\left.70^{\circ} \mathrm{C}\right)$. The lower value of $4.8 \times 10^{-5} \mathrm{~mole} /\left(\mathrm{L}^{*} \mathrm{hr}\right)$ at $70^{\circ} \mathrm{C}$ demonstrates a low bias value since this value falls below the average of about $5.5 \times 10^{-5}$ mole/ $\left(L^{\star} \mathrm{hr}\right)$ at $55^{\circ} \mathrm{C}$.

Using the average rate values for the 40 and $55^{\circ} \mathrm{C}$ tests and the higher rate value for the $70^{\circ} \mathrm{C}$ test, these initial boron appearance rates increase by about factors of $2.7 \mathrm{X}$ and $2.0 \mathrm{X}$, respectively, as the temperature increases from 40 to $55^{\circ} \mathrm{C}$ and from 55 to $70^{\circ} \mathrm{C}$. These increases in rate resemble the standard kinetic 'rule of thumb' involving. roughly a $2 \mathrm{x}$ increase in reaction rate for every $10{ }^{\circ} \mathrm{C}$ increase in temperature.

The boron appearance rates based on measured phenyl borates (i.e., HPLC) at $70^{\circ} \mathrm{C}$ show better precision than those based on ICP-ES at $70^{\circ} \mathrm{C}$. However this HPLC-derived average rate of about $4 \times 10^{-5} \mathrm{~mole} /(\mathrm{L} * \mathrm{hr})$ is lower than either rate calculated from ICP-ES data (i.e.., 4.8 to 10.8 $\left.\times 10^{-5} \mathrm{~mole} /(\mathrm{L} * \mathrm{hr})\right)$. This average rate at $70^{\circ} \mathrm{C}$ based on measured phenyl borates is also lower than the average boron rate of about $5.2 \times 10^{-5}$ mole/ $(\mathrm{L} * \mathrm{hr})$ calculated at $55^{\circ} \mathrm{C}$ from the measured phenyl borates. One possible explanation for observed decrease in boron appearance rates calculated from the boron measured as the phenyl borates at $70^{\circ} \mathrm{C}$ could be the accompanying relatively prompt decomposition of the intermediates $3 P B, 2 P B$ and $1 P B$ on the time-scale of the initial 100 to 200 hours of testing. For instance, related testing on the copper catalyzed decomposition of these intermediates at $70^{\circ} \mathrm{C}$ indicate all three intermediates can decompose to final organic products benzene and phenol (i.e., organic compounds not containing boron) at reaction times $<200$ hours. 8

Table 13 gives negative values for soluble boron appearance rates in the control samples. The two control samples maintained at 55 and $70{ }^{\circ} \mathrm{C}$ with no additives present showed a significant decrease in soluble TPB-; from an initial average value of $150 \mathrm{mg} / \mathrm{L}$ to about $60 \mathrm{mg} / \mathrm{L}$, over the first 96 hours of testing at elevated temperatures. The soluble TPBvalues were relatively constant at $60 \mathrm{mg} / \mathrm{I}$ observed from 96 hours until the end of testing (see Tables 11 and 12). Since the original anaiyses (i.e.. the 'time zero' data) were performed on filtrates from the initial slurries immediately after slurry preparation at ambient temperatures, the observed decrease'in soluble TPB' over the first 96 hours of testing at 55 to $70^{\circ} \mathrm{C}$ probably represents precipitation of 
soluble TRB-. The soluble boron data also reflect this interpretation. Data from rables 11 and 12, plotted in Figures 13 and 14, indicate that soluble boron decreased in the inttial $96 \mathrm{hr}$. The remaining boron data vary around $(2.3 \pm 0.5) \times 10^{-3} \mathrm{~mole} / \mathrm{x}$ for $55^{\circ} \mathrm{C}$ and $(2.1 \pm 0.5) \times 10^{-3}$ mole/L for $70^{\circ} \mathrm{C}$. The above results indicate that the slurries were not at equilibrium at the start of testing.

There appears a significant decrease in soluble boron for the last data set at both temperatures as shown in Figures 13 and 14 . However, the TPB- data does not reflect this decrease, as was the case for the Initial 96 hour. time period. The variations listed above in soluble boron for these control samples at 55 and $70^{\circ} \mathrm{C}$ represent much less than the total soluble boron increases observed for the tests containing all additives at 55 and $70^{\circ} \mathrm{C}$ (1.e., soluble boron levels reached about 3.5 $\times 10^{-2} \mathrm{~mole} / \mathrm{L}$ and $4.3 \times 10^{-2}$ mole/L at 55 and $70^{\circ} \mathrm{C}$, respectively).

\section{Activation Energy Determination}

A simplified kinetic analysis ${ }^{9}$ of the soluble boron rate data in Tables 1 through 6 was performed. A rigorous analysis of this data will follow In a subsequent report. One may estimate the average rate constant for first-order decomposition of NaTPB from the data for increasing soluble boron. Restricting the analysis to the first $\sim 168 \mathrm{hr}$ of data in a given experiment ensures the presence of solid NaTPB. Also the initial boron appearance rates are calculated over $168 \mathrm{hr}$ (instead of the initial 96 hr) since the above mentioned precipitation appears to have complete by $96 \mathrm{hr}$ of testing. Other assumptions in this treatment include a rapid dissolution of solids replenishes the solution with TPB and that the decomposition of a mole of NaTPB produces a mole of soluble boron, neglecting any precipitation of the ultimate borate product. Under these assumptions, dividing the rate of increase in soluble boron by the initial (saturated) TPB- concentration yields an apparent first-order rate constant for the decomposition of NaTPB. (Note: Given the lack of knowledge of the dissolution rates of NaTPB in these static systems, the derived rate constant servas only as a crude masure for the data set. This mathod of calculation will provide signiflcant negative bias in the estimated sate constants.)

Two columns of Table 13 provide estimates for these first-order rate constants for the respective sets of boron measurements (i.e., via HPLC or ICP-ES, respectively). Figure 15 shows a plot of the logs of these. rate constants from the ICP-ES data versus temperature. Figure 15 indicates an activation energy for NaTPB decomposition of about $43 \pm 20 \mathrm{~kJ} / \mathrm{mole}$ for the temperature range of 40 to $70^{\circ} \mathrm{C}$.

The value of $43 \mathrm{~kJ} / \mathrm{mole}$ for the activation energy determined in this study for decomposition of NaTPB in the presence of many potential catalysts including copper, remains lower than activation energies determined from copper catalyzed TPB- decomposition in aqueous solutions. 10 Activation energies reported in those studies ranged between $86 \mathrm{~kJ} / \mathrm{mole}$ and $140 \mathrm{~kJ} / \mathrm{mole}$. The present activation energies also remain lower than recently reported values determined for copper catalyzed decomposition of the intermediate species 3PB, 2PB and 1PB in aqueous solutions. 8 Activation energies reported in those studies ranged between $82 \mathrm{~kJ} / \mathrm{mole}$ and $107 \mathrm{~kJ} / \mathrm{mole}$. 
Several factors could contribute to the apparent reaction rates and thus affect the activation energies determined in this work. The temperature dependent tetraphenylborate rate of dissolution, the presence of both organic tetraphenylborate sollds and inorganic (sludge and MST) solids, and the presence of potential catalytic species in addition to copper could ali possibly contribute to the observed activation energy determination. The lower activation energy suggests presence of a more effective catalyst than copper.

The kinetic analysis of NaTPB decomposition discussed above strongly depends on the temperature dependent rate of dissolution of solid, NaTPB to form soluble TPB in these slurries. ${ }^{-11}$ A more complete and thorough analysis of various kinetic parameters for the data presented in Tables 1 through 10 of this study will follow. 12 These efforts will analyze the resulting composition data of each test in a comprehensive manner to obtain kinetic data for tetraphenylborate and the intermediates triphenylborane, diphenylborinic acid and phenylboronic acid. These. analyses include an empirically derived fitting term based on the measured rate of soluble boron appearance into solution.

\section{Variability of Duplicate Test:}

The variability of duplicate tests in these studies establishes a basis for analysis of future catalyst identification tests conducted under similar conditions. A measure of the repeatablitity allows one to judge whether or not minor changes, such as removing one or more potential catalysts species from a comprehensive recipe, has a measurable effect on the observed decomposition. Note that the present tests used static conditions with minimal mixing during most of the reaction time. Continuous mixing of the slurry samples during testing would improve precision of replicate tests. Data previously shown in Table 13 representing the initial soluble boron appearance rates (i.e., rates calculated over first $168 \mathrm{hr}$ ) for boron indicate poor precision between duplicate tests for two of the data sets at 40 and $70^{\circ} \mathrm{C}$. Since all of these systems used predominately static environments, a better measure of the variability in these tests would consider decomposition product production rates over larger time increments more representative of the total 1600 hours of testing.

The author reports two measures of variability for duplicate tests performed at 40 to $70^{\circ} \mathrm{C}$. The final, relatively stable decomposition products phenol and soluble boron li.e., these two product species which do not show formation and subsequent decay behavior similar to the more transient species 3PB, 2PB and 1PB) were compared from the duplicate slurries tested in the temperature range of 40 to $70^{\circ} \mathrm{C}$ at various time perlods $(432,1008$ and $1600 \mathrm{hr}$ ) of the tests. Table 14 gives these comparisons. Rhenol concentration levels show relative standard deviations (zRSD) in the range of 48 to $25 \%$ at $40{ }^{\circ} \mathrm{C}$ and 28 to $13 \%$ at $70^{\circ} \mathrm{C}$. The same $8 R S D$ measure is higher for the $55^{\circ} \mathrm{C}$ phenol test data. The values of phenol concentrations in Test 3 at $55^{\circ} \mathrm{C}$ appear possibly low-biased data considering Test 4 at $55^{\circ} \mathrm{C}$ gives final phenol values that fall within the average of the 40 and $70{ }^{\circ} \mathrm{C}$ final phenol average concentrations.

Boron concentration levels show relative standard deviations in the range of 68 to 158 at $40^{\circ} \mathrm{C}, 38$ to 148 at $55^{\circ} \mathrm{C}$ and 168 . to 178 at $70{ }^{\circ} \mathrm{C}$. Note that agreement of the $55^{\circ} \mathrm{C}$ boron data further suggests a bias in the $55^{\circ} \mathrm{C}$ data for phenol. This measure of variability involying 
soluble boron likely better indicates NaTPB decomposition than the phenol measure since soluble boron directly results from decomposition. In contrast, phenol forms as a result of several intermediate. decomposition steps influenced by the presence of oxygen.

\section{Influence of Solid Additives on NaTPB Decomposition}

Tests 7 to 10 investigate the influence of solid sludge additives (i.e.. Tests 8 and 10) and solid sludge and monosodium titanate (MST) additives (i.e., Tests 7 and 9) on NaTPB decomposition. Tests 7 through 10 included both sets of soluble organic and metal additives shown in Table A-2 of Appendix A. Note also from Table A-2 that about $20 \%$ of the total noble metals $\mathrm{Ru}, \mathrm{Pd}$ and $\mathrm{Rh}$ come from the soluble metal additives group (i.e., removal of sludge solids does not remove all noble metals from. the comprehensive recipe). The effect of varlous additives discussed below derive from data shown in Tables 3 through 10 and plotted in Figures 7 through 12 and Figures 16 through 19. The initial rates of increase in soluble boron concentrations from Table 13 also aid in the discussion of these effects.

\section{Effects of Solid MST Additives}

For both the 55 and $70^{\circ} \mathrm{C}$ tests, the effects of MST addition on TPB decomposition do not appear significant. Figure 16 repeats some of the data from Figure 10 (Test 8, no MST added) and Figure 7 (Tests 3 and 4, all additives present) for the $55^{\circ} \mathrm{C}$ tests for comparison. Figure 16 shows little difference in the kinetic behavior and concentration magnitudes of both total soluble boron (ICP-ES) and the phenyl borates (HPLC). Figure 17 repeats some of the data from Figure 12 (Test 10, no MST added) and Figure 8 (Tests 5 and 6 , all additives present) for the $70{ }^{\circ} \mathrm{C}$ tests for comparison. Figure 17 shows little difference in the kinetic behavior and concentration magnitudes of both total soluble boron (ICP-ES) and the phenyl borates (HPIC).

Recall that data plotted as solid squares and open squares in both Figures 16 and 17 represent average values from duplicate samples with some associated variability at each point in time. The data from each test without MST solids at $55^{\circ} \mathrm{C}$ (Test 8) and $70^{\circ} \mathrm{C}$ (Test 10) fall within the range of the comparable average (plus or minus one standard deviation) calculated from the duplicate tests. Table 15 gives the comparisons suggested above using total soluble boron data at various time intervals. Removal of the solid.MST additive does not significantly alter these boron concentration levels.

Similar conclusions to those reached above arise from visual inspection of the concentration plots and by comparison of the kinetic data shown in Table 13: (Table 15 also provides this data for comparison.) Initial boron production rates appear similar, though higher, for Test 8 (no MST added) compared to the average of duplicate Tests 3 and 4 (all additives present) for the $55^{\circ} \mathrm{C}$ tests. Soluble boron production rates seem similar, and also-higher, for Test 10 (no MST added) compared to the average from duplicate Tests 5 and 6 (all additives present) for the $70{ }^{\circ} \mathrm{C}$ tests.

Processes involving energy deposition into systems containing certain titanate materials can produce catalytically active surfaces on the titanate solids. The forms of energy deposition most often studied include either photolytic or radiolytic. As indicated in the 
introduction of the present study, this study did not allow. for any synergistic activity due to presence of monosodium titanate in a radiation field.

\section{Effects of solid Sludge Additives}

For the $55^{\circ} \mathrm{C}$ tests, the effects of solid sludge additives on NaTPB decomposition do not appear significant. Figure 18 repeats some of the data from Eigure 9 (Test 7, soluble additives only) and Figure 7. (Tests 3 and 4 , all additives present) for the $55^{\circ} \mathrm{C}$ tests for comparison. Figure 18 shows insignificant differences in the kinetic behavior and concentration magnitudes of both total soluble boron (ICP-ES) and the phenyl borates (HPLC). Recall that data plotted as solid squares and open squares Figures 18 are average values from duplicate samples with some associated variability at each point in time. Table 15 provides the comparisons of soluble boron concentrations at various time intervals and initial appearance rates. Removal of solid additives from the comprehensive recipe had the effect of decreasing the final soluble boron levels at $55^{\circ} \mathrm{C}$ by only about $15 \%$ or less when compared to the average values from the comprehensive catalyst systems at $55^{\circ} \mathrm{C}$.

For the $70^{\circ} \mathrm{C}$ tests, Figure 19 repeats some of the data from Figure 11 (Test 9, soluble additives only) and Figure 8. (Tests 5 and 6 , all additives present) for comparison. Figure 19 shows measurable differences in the concentration magnitudes of total solubie boron (ICP-ES). (Table 15 also provides the comparisons above using boron (ICP-ES) data.) Removal of solid additives from the comprehensive recipe had the effect of decreasing soluble boron levels at $70^{\circ} \mathrm{C}$ by about 25\%, when compared to'the average values from the comprehensive catalyst systems at $70^{\circ} \mathrm{C}$. Comparison of the phenyl borate data plotted in Eigure 19 also.indicate that phenyl borate species persisted at longer times in Test 9 with soluble additives only. This indicates a less reactive system compared to the Tests 5 and 6 that contained the comprehensive catalyst system.

Similar conclusions to those reached above, arising from visual inspection of the concentration plots, can be reached by comparison of the kinetic data shown in Table.13 (or Table 15). A soluble boron production rate of $4.8 \times 10^{-5} \mathrm{~mole} /\left(\mathrm{I} \mathrm{hr}_{\mathrm{h}}\right.$ ) at $55^{\circ} \mathrm{C}$ for Test 7 (soluble additives only). is only slightly. lower compared to the average rate of $5.5 \times 10^{-5} \mathrm{~mole} /(\mathrm{L} * \mathrm{hr})$ from duplicate Tests 3 and 4 containing all additives at $55^{\circ} \mathrm{C}$. A soluble boron production rate of $3.8 \times 10^{-5}$ mole/ (I*hr) at $70^{\circ} \mathrm{C}$ for Test 9 (soluble additives only) is lower compared to the average rate of $7.8 \times 10^{-5} \mathrm{~mole} /(\mathrm{L} * \mathrm{hr})$ from duplicate Tests 5 and 6 containing all additives at $70^{\circ} \mathrm{C}$.

From the above discussion, effects observed in the absence of solid additives (i.e., less overall NaTPB decomposition as concluded from. comparison of soluble boron values) are shown to be only marginally significant in the $55^{\circ} \mathrm{C}$ data and significant in the $70^{\circ} \mathrm{C}$ data when sludge solids were excluded. It follows that this effect results from the lack of sludge solids instead of the lack of MST solids. 
Analyses of Sluxxies fox NaTPB Sollds and Potassium Ion

Initial Attemets to Analyze for NaTPB solids

Researchers analyzed slurry samples at the completion of the decomposition tests for the presence of both NaTPB solids and soluble potassium ion. The original slurry used for all test samples was also analyzed. This original slurry was maintained at ambient temperature for the duration of the tests. NaTPB solids were analyzed by diluting a small amount of ( $\mathrm{K}, \mathrm{Na}$ ) IPB slurxy with deionized water (about 1 gram of slurry mixed with $5 \mathrm{ml}$ of water), followed by agitation, filtration and analysis of the resulting filtrate for TPB ${ }^{-}$. Dilution of the (K,Na)TPB slurry with water would allow the more soluble NaTpB to readily dissolve leaving the much less soluble KTPB as solid. Results from these tests indicate that not all of the solid NaTPB was dissolved. For instance, the original slurry tested in the procedure above indicated only about one third of the targeted amount of NaTPB was found to be present in the slurry. Table 16 reports the results of these slurry dissolution tests in a qualitative manner only (i.e., dissolved NaTPB present (yes) or not present (no) above HPIC analytical detection limits of about $20 \mathrm{mg} / \mathrm{I}$ ).

\section{Bepeat Analyses for NaTPB Solids from Original'Batch Slurry}

The dissolution testing was repeated in duplicate with the original slurry. Unfortunately, the reacted slurries from Tests 1 to 12 had been disposed at the time of this follow-up analysis. A larger volume of dilution water, $40 \mathrm{~mL}$ compared to $5 \mathrm{~mL}$ previously, was used in dissolving the 1 gram slurry portions. As shown in Table 16, this increased dilution measure of NaTPB solids indicates $12,300 \pm 600 \mathrm{mg} / \mathrm{L}$ NaTPB solid present in the original slurry (compared to only $7,200 \mathrm{mg} / \mathrm{I}$ NaTPB solids measured from the previous single analysis of original slurry). This latter measure appears more accurate since a larger. dilution water volume was used and the diluted slurries were stirred for at least 12 hours before filtration and submission for TPB analysis.

The last column of Table 16 also shows the calculated equivalent amounts of NaTPB represented by the soluble boron measured via ICP-ES in the filtrates. These calculations indicate that $6,240 \mathrm{mg} / \mathrm{I}$ at $40^{\circ} \mathrm{C}, 10,560$ $\mathrm{mg} / \mathrm{L}$ at $55^{\circ} \mathrm{C}$ and $13,680 \mathrm{mg} / \mathrm{L}$ at $70^{\circ} \mathrm{C}$ solid NaTPB decomposed during testing. Comparing these values to the experimentally determined value of about $12,300^{\circ} \mathrm{mg} / \mathrm{L}$ NaTPB solids in the original slurry indicates that about 50\%, 85\% and $100 \%$ of the NaTPB solids decomposed at 40, 55 and $70{ }^{\circ} \mathrm{C}$, respectively. Note that the $13,320 \mathrm{mg} / \mathrm{I}$ to $13,680 \mathrm{mg} / \mathrm{I}$ NaTPB solids calculated to have dissolved/decomposed in the $70{ }^{\circ} \mathrm{C}$. tests slightly exceeds the calculated $12,300 \pm 600 \mathrm{mg} / \mathrm{L}$ total NaTPB solid experimentally determined (based on soluble TPB data) in the repeat analyses of the original slurry. This difference may reflect additional dissolution of KTPB solids at the higher temperatures of 55 and $70{ }^{\circ} \mathrm{C}$ (see below).

\section{Rotassium Analyses from Slurry Filtrates}

Researchers also obtained potassium analyses from filtrates of the fully reacted slurries with no dilutions involved. The original slurry was also tested. Table 17. shows the results from these analyses in the first column of numerical data. The second column of numerical data. indicate the corresponding amounts of equivalent KTPB dissolved during testing. Table 17 also repeats some of the data shown previously in 
Table 16 for equivalent NaTPB dissolved based on final soluble boron data for comparison. Data shown in Table 17 indicate very little soluble potassium ion present in the original siurry, the control test slurries at 55 and $70^{\circ} \mathrm{C}$ containing no additives, and the slurries tested at $40^{\circ} \mathrm{C}$ with additives present. As shown in Table 17 these low levels of soluble potassium of less than about $3.7 \mathrm{mg} / \mathrm{L}$ in the slurry filtrates indicate that less than $36 \mathrm{mg} / \mathrm{L}$ of the original targeted $48,000 \mathrm{mg} / \mathrm{L}$ KTPB solids dissolved over the 1600 hours of testing in either the control test slurries at 55 an $70^{\circ} \mathrm{C}$ containing no additives, or the slurries tested at $40^{\circ} \mathrm{C}$, with all additives present. Recall data in Table 16 show that there was excess NaTPB also present in these slurries.

Potassium data for all final test samples with additives present at temperatures of 55 and $70{ }^{\circ} \mathrm{C}$ indicate that varying amounts of the targeted original 4.0 wt KTPB sollds (or $48,000 \mathrm{mg} / \mathrm{L}$ KTPB solids) dissolved during testing. These values approached $1,920 \mathrm{mg} / \mathrm{L}$ KTPB at $55^{\circ} \mathrm{C}$ and $4,656 \mathrm{mg} / \mathrm{L} \mathrm{KTPB}$ solids at $70{ }^{\circ} \mathrm{C}$. Note from Tables 3 through 10 that the soluble TPB values for these final test samples were all below the HPLC detection limits of about $20 \mathrm{mg} / \mathrm{L}$. The amounts of potassium found in the filtrates (ranging from 6.6 to $506 \mathrm{mg} / \mathrm{L}$ ) exceed the equilibrium values calculated from the KTPB solubility product constant $\left(K_{\mathrm{Sp}}\right)$ at 55 and $70^{\circ} \mathrm{C} .11$ 'Using the temperature dependent equation for calculation of $\mathrm{K}_{\mathrm{Sp}}$ for KTPB and the experimentally determined activity coefficients found in Ref. 11, one can show based on KTPB solubility alone that less than $2 \mathrm{mg} / \mathrm{L}$ of soluble potassium would be expected in these slurries. These calculations assume that all NaTPB has been decomposed. Table 17 shows that measured values of potassium approached about $209 \mathrm{mg} / \mathrm{L}$ and $506 \mathrm{mg} / \mathrm{L}$, respectively, at 55 to $70{ }^{\circ} \mathrm{C}$.

The presence of soluble potassium at the measured levels in these slurries indicates either solid KTPB decomposition or decomposition of essentially all excess NaTPB with subsequent dissolution of KTPB solids. Preliminary calculations involving the temperature dependent dissolution equilibrium of KTPB and NaTPB solids11 coupled with the decomposition kinetics of soluble TPB indicate that the magnitudes of soluble potassium analyzed fall within the expected dissolution of solid KTPB. Dissolution of solid KTPB would occur as the solid NaTPB fully depletes from these slurries by decomposition of soluble TPB in solution. Note that the two tests showing highest amounts of NaTPB decomposition (i.e., Tests 5 and 10 at $70^{\circ} \mathrm{C}$ in Table 16). also show the highest amounits of analyzed soluble potassium (i.e., Tests 5 and 10 in rable 17).

Comparison of Present ( $R, 2 \mathrm{Na}$ ) IRB Sluxry Decomposition Tests with Rrevious Tank 48 Bata

The main objectives of the present study weire to establish the extent of tetraphenylborate decomposition reactions in the temperature range of 40 to $70^{\circ} \mathrm{C}$ over about 1500 hours of testing, and to demonstrate that the catalyst recipe tested provides an all-inclusive or near-complete set of additives from which statistically designed catalyst identification

tests could follow. 5 The present tests were conducted to verify this simulant recipe results in a reaction that approximates curient understanding of rank $48 \mathrm{H}$ behavior in December of 1995. Comparison of several measured decomposition products in the present tests with similar measurements from Tank $48 \mathrm{H}$ provide verification that the present 
simulant recipe does indeed result in reaction similar to that observed previously in Tank $48 \mathrm{H}$.

Table 18 shows a comparison of relevant data from the present tests at 40 to $55^{\circ} \mathrm{C}$ to data obtained from Tank $48 \mathrm{H}$. All Tank $48 \mathrm{H}$ data shown in Table 18 come from a previous report (see-specifically Figure 3 and Table 2 from Ref. 1). Data in the present study were collected over a testing period of about 1600 hours or 66 days. The Tank $48 \mathrm{H}$ data was collected over an approximate time period of six months or 180 days from October 12, 1995 until April 15 of 1996 (see Table 2 of Ref. 1). The magnitudes of all species shown in Table 18 represent maximum amounts produced over the approximate time periods indicated. Table 18 also shows estimated production rates of the various species over the appropriate time periods for comparison.

The organic decomposition products benzene, 1PB and soluble boron reach comparable concentration levels when comparing data from Tank $48 \mathrm{H}$ to data from the present studies at constant temperatures of 40 and $55{ }^{\circ} \mathrm{C}$. In most cases, the estimated rates of production for the various species also compare favorably. Phenol production in the laboratory tests at 40 or $55^{\circ} \mathrm{C}$, however, at least tripled that of Tank $48 \mathrm{H}$. This difference presumably results from higher levels of air present in the air-sealed bottle tests relative to the more inerted atmosphere in Tank $48 \mathrm{H}$ (see discussion below on 'Differences in Present Tests Compared to Tank $48 \mathrm{~K}^{\prime}$ ).

Potassium measures are comparable for the Tank $48 \mathrm{H}$ data and the $40^{\circ} \mathrm{C}$ tests, whereas higher potassium rates were observed in the $55^{\circ} \mathrm{C}$ tests. Tank $48 \mathrm{H}$ recorded temperatures ranged from 33 to $52{ }^{\circ} \mathrm{C}$ from August 31 , 1995 to mid-November of 1995. The tank temperatures steadily decreased to about $25{ }^{\circ} \mathrm{C}$ by inid-December and remained at the lower level until April of 1996. The time-profile of temperatures recorded in Tank 48H proves important when comparing data from Tank $48 \mathrm{H}$ to thé present laboratory tests. Significant increases in soluble boron, 1PB and phenol existed in Tank $48 \mathrm{H}$ at the beginning of December, 1995 (see Table 2 of Ref. 1), Indicating some decomposition. Samples obtained from Tank $48 \mathrm{H}$ on December 18 indicated that more than $95 \%$ of the excess NaTPB had decomposed. 1 Thus most of the decomposition appears to have taken place in Tank $48 \mathrm{k}$ during the relatively high temperature $\left(33^{\circ}\right.$ to $\left.52{ }^{\circ} \mathrm{C}\right)$ period preceding the mid-December (and latter) temperatures of $25^{\circ} \mathrm{C}$.

Therefore this temperature range of 33 to $52{ }^{\circ} \mathrm{C}$ compares reasonably well to the two present data sets at 40 and $55^{\circ} \mathrm{C}$ used in Table 18 of this. report. The potassium data for the $55^{\circ} \mathrm{C}$ tests especially reflect these comparisons when contrasted to the amounts of potassium produced in the Tank $48 \mathrm{H}$ samples or the $40^{\circ} \mathrm{C}$ data. Rates in Tank $48 \mathrm{H}$ remained much lower because the temperature remained low after consumption of excess TPB $^{-}$.

\section{Differences in Present Test's Compared to Tank $48 \mathrm{H}$}

Although the present tests simulate the slurries and additives thought present in Tank 48H, there exists several differences in the present studies and the conditions of Tank 48H. The present investigation did not involve any radiation effects on the thermal catalytic NaTPB decomposition. The radiation field calculated in Tank $48 \mathrm{H}$, about 24,000 rad/day, would contribute some $7.25 \times 10^{5}$ rads of accumulated dose over each month. 1 The effects of these levels of ionizing radiation on the chemical decomposition involving potential catalytic species present in 
current tests has yet to be studied in the temperature range of 40 to $55^{\circ} \mathrm{C}$. Previous testing ${ }^{1}$ at $70^{\circ} \mathrm{C}$ concluded that simulated doses did not have significant effects on NaTPB decomposition using a potential catalyst recipe nearly identical to the one used in this most recent. work (see Table A-2).

Another difference in these tests was the relative abundance of oxygen from air contained within the sealed slurries in the laboratory tests. About 5 to $10 \mathrm{cc}$ of air was introduced into these systems each time an analysis was performed. In contrast, Tank $48 \mathrm{H}$ atmosphere was predominately inerted with nitrogen to attain a nominal 5 vols oxygen. During the time period from early October 1995 to April 1995, air was present in Tank 48H for only two relatively brief $\sim 5$ day periods. During these two periods in which nitrogen ventilation was halted, the atmosphere was measured to contain 20 volo and 10 vol\% oxygen, respectively. At all other times the atmosphere was measured to contain about 5 voli oxygen (see Figure 4 of Ref. 1). The effects of oxygen on the copper catalyzed decomposition of TPB in homogeneous aqueous solutions have recently been reported:10;13 oxygen was found to inhibit the overall decomposition of $\mathrm{TPB}^{-}$in the copper-only studies.

The specific preparation of the mixed $(\mathrm{K}, \mathrm{Na})$ TPB slurry systems also differed in these investigations compared to Tank $48 \mathrm{H}$ processes. This study involved preparation of the mixed $(\mathrm{K}, \mathrm{Na}) \mathrm{TPB}$ solids in alkaline solution by adding concentrated soluble TPB solutions to a potassiumcontaining caustic solution, thereby forming the slurry targeted to contain approximately 5.5 wt of (K, Na) TPB solids. The slurry preparation was complete in about one hour. The remaining salts were then mixed into the slurry within about one hour. Finaliy, the various potentially catalytic additives (see Table $\mathrm{A}-2$ ) were added in just prior to testing. In Tank $48 \mathrm{H}$ a concentrated caustic soluble $\mathrm{TPB}^{-}$solution is typically added to an existing slurry containing approximately 1 wt $\frac{}{6}$ (K, Na) TPB solids, in the waste tank containing all of the potential catalytic additives. 1 The tank contents are then mixed to promote precipitation. The details of addition and mixing order related to these two different procedures, and any effects this order might have on the onset and rate of TPB decomposition in the presence of potential catalytic species, have not been studied.

\section{CONCLUSIONS}

Researchers studied the thermal catalytic decomposition of tetraphenylborate in mixed ( $K, N a)$ TPB slurries contained in concentrated salt solutions between 40 and $70{ }^{\circ} \mathrm{C}$. The slurries contained additives thought to comprehensively represent feeds to Tank $48 \mathrm{H}$. Comparison of several measures of tetraphenylborate decomposition for this study and previous Tank 48H activities indicates that the present simulant recipe does result in reaction similar to that observed previously in Tank $48 \mathrm{H}$. The activation energy for decomposition of NaTPB in the slurries is $43 \pm 20 \mathrm{~kJ} / \mathrm{mole}$ in the temperature range of 40 to $70^{\circ} \mathrm{C}$.'

Removing both solid sludge additives and solid monosodium titanate additives from the.comprehensive potential catalytic recipe resulted in lower decomposition rates and decreased magnitudes of soluble boron products at $70^{\circ} \mathrm{C}$. The decreases in NaTPB decomposition were found less significant (i.e., effects less than $15 \%$ ) at $55^{\circ} \mathrm{C}$. The effects were about $25 \%$ at $70^{\circ} \mathrm{C}$ when compared to the averages of duplicate tests 
containing all additives: When only solid monosodium titanate was removed from the comprehensive potential catalytic recipe, no significant effects on decomposition were observed relative to decomposition observed using the comprehensive potential catalysts recipe at 55 and $70^{\circ} \mathrm{C}$.

Thus the present tests suggest that solid MST additives do not contribute significantly to NaTPB decomposition. From these preliminary tests, it can be assumed that solid sludge additives used in these particular experiments, which contained portions of the total noble metals and a portion of the total copper, do increase NaTPB decomposition. The effects were less apparent at $55^{\circ} \mathrm{C}$. It remains to be seen whether these effects observed with the solid sludge are due to the increased amounts of copper, increased amounts of noble metals, or whether the sludge solids provide a heterogeneous catalysis reaction site. Current catalyst identification tests using sludges formulated without copper present will address these questions. 5

Duplicate slurries tested as static, unstirred systems with the comprehensive catalyst recipe in the temperature range of 40 to $70{ }^{\circ} \mathrm{C}$ indicate variability of $2 \%$ to $25 \%$ and 38 to 178 'in measurements of phenol and soluble boron, respectively. This level of variability can be used to judge in future decomposition tests the relative effects of specific additives on the catalytic chemical processes. As suggested in the text, boron analyses are considered a better measure of decomposition since phenol production is influenced by oxygen content.

Measurable amounts of NaTPB solids were detected in slurries tested at 40 and $55^{\circ} \mathrm{C}$ for 1600 hours, Indicating incomplete decomposition of the targeted starting $18,000 \mathrm{mg} / \mathrm{L}$ NaTPB solids. Similar analyses indicate possible complete decomposition of NaTPB at $70^{\circ} \mathrm{C}$ in certain tests. Theorétical amounts of decomposed NaTPB based on soluble boron analyses in the fully reacted $70^{\circ} \mathrm{C}$ tests approached $13,680 \mathrm{mg} / \mathrm{L}$, which were slightly higher than the measured amounts of NaTPB equal to $12,300 \pm 600 \mathrm{mg} / \mathrm{L}$ determined from dissolution of the original slurry:

Insignificant amounts of potassium ion were detected in filtrates of reacted slurries containing potential catalytic additives at $40^{\circ} \mathrm{C}$ for 1600 hours and in filtrates of reacted slurries containing no additives at 55 and $70^{\circ} \mathrm{C}$ for 1600 hours. This is consistent with the presence of excess NaTPB. Similar analyses showed measurable amounts of potassium from filtrates of reacted slurries containing potential catalytic additives at both 55 and $70^{\circ} \mathrm{C}$ for 1600 hours, indicating a maximum KTPB concentration of about $1,920 \mathrm{mg} / \mathrm{I}$ and $4,656 \mathrm{mg} / \mathrm{L} \mathrm{KTPB}$, respectively. These potassium amounts result from either decomposition of KTPB solids or TPB decomposition and subsequent KTPB dissolution. These tests suggest that about 48 and 108 of the theoretical 4.0 wt 8 KTPB solids (or 48,000 mg/L KTPB solids) decomposed after 1600 hours of testing at the respective test temperatures of 55 and $70{ }^{\circ} \mathrm{C}$. Preliminary calculations involving the temperatu're dependent solubility equilibrium of KTPB indicate that decomposition of TPB ${ }^{-}$and KTPB dissolution processes may adequately explain the observed concentrations of soluble potassium at these higher temperatures of 55 and $70^{\circ} \mathrm{C}$. 
16 WSRC-TR-97-0046, Rev. 0

APRROVATS

Waire O.Walker

$5 / 6 / 97$

D. D. Walker, WRTS Design Check

(per Manual E7, Procedure 2.40)$$
\text { S. hem }
$$

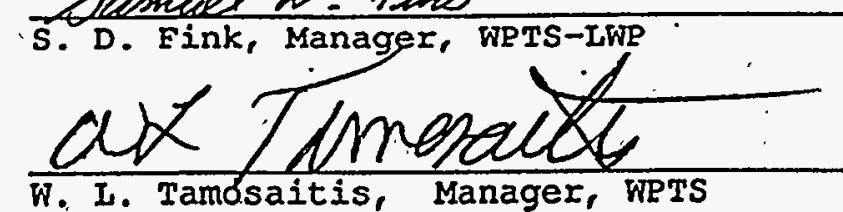$$
\text { Th. ज. . Phant }
$$

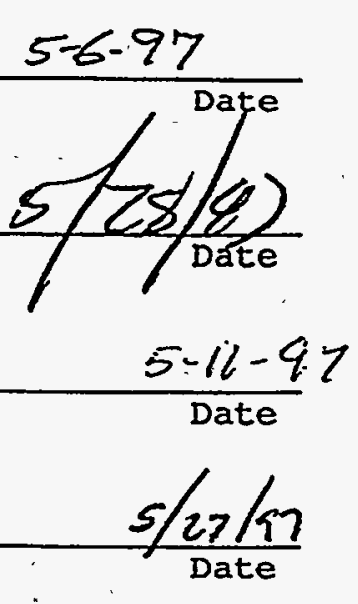


Table 1. Tost 1: $40{ }^{\circ} \mathrm{C}$, Soluble organics and molals, Solld sludgo and MST additlves

\begin{tabular}{|c|c|c|c|c|c|c|c|c|c|c|c|}
\hline $\begin{array}{l}\text { Reaction Time } \\
\text { (hr) }\end{array}$ & $\begin{array}{l}\text { (mg/L) } \\
\text { Benzene }\end{array}$ & $\begin{array}{c}\text { Benzene } \\
\text { Rate } \\
\text { (ug/(L·hr)) }\end{array}$ & - & $\begin{array}{c}\text { (mole/L) } \\
\text { TPB }\end{array}$ & $\begin{array}{c}\text { (mole/L) } \\
\text { 3PB }\end{array}$ & $\begin{array}{c}\text { (mole/L) } \\
2 P B\end{array}$ & $\begin{array}{c}\text { (molo/L) } \\
\text { PBA }\end{array}$ & $\begin{array}{c}\text { (molo/L) } \\
\text { Phonol }\end{array}$ & $\begin{array}{l}\text { Soluble Boron } \\
\text { (molerL) } \\
\text { Boron(ICP.ES) }\end{array}$ & $\begin{array}{c}\text { (molo/h) } \\
\text { Boron } \\
\text { (from organlcs) }\end{array}$ & $\begin{array}{l}\text { Equivalont } \\
\text { NaTPB(mon) }\end{array}$ \\
\hline 0 & 45 & - & & 4.76E-04 & 2.64E-04 & 1.42E-04 & 1.64E-04 & 7.23E-04 & 4.18E-03 & $1.05 E-03$ & 1431 \\
\hline 96 & 39 & 0 & & $3.20 \mathrm{E}-04$ & 5.53E.04. & $9.86 E-04$ & 1.16E-03 & $1.93 E-03$ & 4.71E-03 & 3.02E-03 & 1613 \\
\hline 168 & 379 & 1988 & & 2.51E-04 & $1.42 \mathrm{E}-03$ & 3.33E-03 & 2.51E.03 & 2.84E.03 & 9.36E-03 & $7.51 E-03$ & 3203 \\
\hline 288 & 325 & 872 & & 1.57E-04 & $1.23 \mathrm{E}-03$ & $3.49 E-03$ & 4.41E-03 & 4.32E-03 & 1.04E-02 & $0.29 E-03$ & 3552 \\
\hline 432 & 348 & 701 & & 8.14E-05 & $1.18 \mathrm{E}-03$ & $2.21 E-03$ & 4.97E-03 & $6.26 \mathrm{E}-03$ & 1.31E-02 & $8.43 E-03$ & 4498 \\
\hline 672 & 862 & 1216 & & 7.62E-05 & 9.54E-04 & 1.24E-03 & $3.81 E-03$ & 8.85E-03 & 1.74E-02 & $6.08 E-03$ & 5957. \\
\hline 1008 & $\cdot 1274$ & 1218 & & 4.39E-05 & 4.71E-04 & B.53E-04 & $2.46 \mathrm{E}-03$ & 9.90E-03 & 2.00E-02 & 3.83E-03 & 6829 \\
\hline 1296 & 2165 & 1638 & & $0.00 E+00$ & $2.48 E-04$ & 7.77E-04 & 1.62E-03 & 1.33E-02 & 2.22E-02 & 2.64E-03 & 7613. \\
\hline 1608 & 2034 & 1237 & & 1.25E-05 & 1.11E-04 & 4.53E-04 & $9.43 E-04$ & 1.43E-02 & 2.28E-02 & $1.52 E-03$ & 7735 \\
\hline & & Rato Data & $\begin{array}{l}96 \mathrm{hrs} \\
168 \mathrm{hrs} \\
288 \mathrm{hrs} \\
\end{array}$ & $\begin{array}{l}-1.63 E-06 \\
-1.34 E-08 \\
-1.11 E-08 \\
\end{array}$ & $\begin{array}{l}\text { mole/(L"hr) } \\
\text { mole/(L*hr) } \\
\text { mole/(L"hr) }\end{array}$ & & - & $\begin{array}{l}98 \text { hrs } \\
188 \text { hrs } \\
288 \text { hrs } \\
\end{array}$ & $\begin{array}{l}5.53 E-06 \\
3.08 E-05 \\
2.16 E-05 \\
\end{array}$ & $\begin{array}{l}2.05 E-05 \\
3.85 E-05 \\
2.86 E-05 \\
\end{array}$ & $\begin{array}{l}\text { mole/(L"hr) } \\
\text { mole/(L'hr) } \\
\text { mole/(L'hr) } \\
\end{array}$ \\
\hline
\end{tabular}

Tabile 2 Tost 2: $40^{\circ} \mathrm{C}$, soluble organice and motale, solld sludge and ist additues.

\begin{tabular}{|c|c|c|c|c|c|c|c|c|c|c|c|}
\hline $\begin{array}{l}\text { Reactlon . Tlme } \\
\text { (hr) }\end{array}$ & $\begin{array}{c}\text { (mg/L) } \\
\text { Benzeno }\end{array}$ & $\begin{array}{l}\text { Benzene } \\
\text { - Pate } \\
\text { (ug/(L"hr)) }\end{array}$ & & $\begin{array}{c}(\mathrm{mole} / \mathrm{L}) \\
\text { TPB. }\end{array}$ & $\begin{array}{c}\text { (mole/L) } \\
3 P B\end{array}$ & $\begin{array}{c}(\mathrm{mole} / \mathrm{L}) \\
2 \mathrm{~PB}\end{array}$ & $\begin{array}{c}\text { (mole/L) } \\
\text { PBA }\end{array}$ & $\begin{array}{c}\text { (mole/L) } \\
\text { Phenol }\end{array}$ & $\begin{array}{c}\text { Soluble Borron } \\
\text { (molen) } \\
\text { Boron(KCP.ES) }\end{array}$ & $\begin{array}{c}\text { (mole/L) } \\
\text { Boron } \\
\text { (from organica) }\end{array}$ & $\begin{array}{l}\text { Equivalent } \\
\text { NaTPB(mg/L) }\end{array}$ \\
\hline 0 & 45 & - & & 4.76E-04 & 2.64E-04 & $1.42 E-04$ & $1.64 E-04$ & 7.23E-04 & 4.18E-03 & $1.05 \mathrm{E}-03$ & 1431 \\
\hline 96 & 68 & $240^{\circ}$ & & $3.54 E-04$ & 4.96E-04 & $3.42 E=04$ & 4.84E-04 & 1.19E-03 & $4.10 \mathrm{E}-03$ & $1.68 E-03$ & 1434 \\
\hline-168 & 247 & 1202 & * & $3.20 \mathrm{E} \cdot 04$ & 8.22E-04 & $1.26 \mathrm{E}-03$ & $1.26 \mathrm{E}-03$ & $1.90 E-03$ & 5.72E-03 & $3.68 \mathrm{E}-03$ & 1958 \\
\hline 288 & 280 & 816 & & $1.82 E-04$ & 9.95E.04 & 2.99E-03 & 2.88E-03 & 2.94E-03 & $8.69 \mathrm{E}-03$ & 7.05E-03 & 2873 \\
\hline 432 & 512 & 1081 & & $1.63 \mathrm{E}-04$ & $1.07 E-03$ & 2.44E-03 & 4.03E-03 & 4.39E-03 & $1.06 E-02$ & 7.71E-03 & 3633 \\
\hline 672 & 1182 & 1892 & & 1.13E-04 & $0.08 \mathrm{E}-04$ & 1.51E-03 & $3.88 \mathrm{E}-03$ & 7.23E-03 & 1.66E-02 & $6.49 E-03$ & 5322 \\
\hline 1008 & 1519 & 1462 & & 5.64E-05 & 4.63E-04 & 8.31E-0i & 2.47E-03 & 9.19E.03 & $1.73 \mathrm{E}-02$ & 3.82E-03 & 5936 \\
\hline 1296 & 2271 & 1718 & & 2.82E-05 & $2.48 E-04$ & 6.40E-04 & $1.60 E-03$ & $1.21 E-02$ & 2.01E-02 & 2.61E-03 & 6876 \\
\hline 1608 & 1343 & 807 & & $0.00 E+00$ & 1.07E-04 & 4.13E-04 & $9.19 E-04$ & 1.34E-02 & 2.07E-02 & $1.44 E-03$ & 7088 \\
\hline$=$ & & Rate Data & $\begin{array}{l}96 \text { hrs } \\
168 \text { hrs } \\
288 \text { hrs }\end{array}$ & $\begin{array}{l}-1.27 E-08 \\
-9.32 E-07 \\
-1.02 E-06\end{array}$ & $\begin{array}{l}\text { molo/(L'hr) } \\
\text { mole/(L'hr) } \\
\text { mole/(L'hr) }\end{array}$ & $\gamma$ & & $\begin{array}{l}96 \text { hrs } \\
168 \text { hrs } \\
288 \text { hrs }\end{array}$ & $\begin{array}{l}\text { 8.67E-08 } \\
0.17 \text { E-08 } \\
1.56 \mathrm{E}-05 \\
\end{array}$ & $\begin{array}{l}\text { 6.65E-0B } \\
1.66 \mathrm{E}-05 \\
2.08 \mathrm{E}-05 \\
\end{array}$ & $\begin{array}{l}\text { mole/(L"hr) } \\
\text { mole/(L"hr) } \\
\text { mole/(L"hr) }\end{array}$ \\
\hline
\end{tabular}


Tablo 3 Test 3: $55^{\circ} \mathrm{C}$, Soluble organles and motals, Solld sludgo and MST addltivos

\begin{tabular}{|c|c|c|c|c|c|c|c|c|c|c|c|}
\hline $\begin{array}{l}\text { Reaction Tme } \\
\text { (hi) }\end{array}$ & $\begin{array}{r}\text { (mg/L) } \\
\text { Benzeno }\end{array}$ & $\begin{array}{c}\text { Benzene } \\
\text { Rate } \\
\text { (ug/(L“hr)) }\end{array}$ & & $\begin{array}{c}\text { (mol/l L) } \\
\text { TPB }\end{array}$ & $\begin{array}{c}(\mathrm{mol} / \mathrm{L}) \\
3 \mathrm{~PB}\end{array}$ & $\begin{array}{c}(\mathrm{mol} / \mathrm{L}) \\
2 \mathrm{~PB}\end{array}$ & $\begin{array}{c}\text { (mol/h) } \\
\text { PBA }\end{array}$ & $\begin{array}{c}\text { (mol/L) } \\
\text { Phenol }\end{array}$ & $\begin{array}{l}\text { Soluble Boron } \\
\text { (molen) } \\
\text { Boron(ICP.ES) }\end{array}$ & $\begin{array}{c}\text { (molell) } \\
\text { Boron } \\
\text { (from ofganles) }\end{array}$ & $\begin{array}{c}\text { Equivilont } \\
\text { NaTPB(mon) }\end{array}$ \\
\hline 0 & 45 & - & & 4.76E-04 & 2.84E.04 & $1.42 E \cdot 04$ & $1.64 E-04$ & $7.23=04$ & 4.18E-03 & $1.05 E-03$ & $1431^{\circ}$ \\
\hline 96 & 89 & 458 & & $1.82 E-04$ & 1.52E-03 & $3.58 \mathrm{E} .03$ & 3.42E-03 & 2.92E.03 & $9.70 E-03$ & 8.70E-03 & 3320 \\
\hline 168 & 876 & 5542 & & $1.32 E-04$ & 1.18E-03 & 3.985 .03 & $5.83 E-03$ & $4.09 E-03$ & $1.34 E \cdot 02$ & $1.11 E-02$ & 4589 \\
\hline 288 & 1046 & 3476 & & $3.45 E-05$ & 6.24E-04 & $2.89 E-03$ & $9.09 E-03$ & 4.88E-03 & $1.67 E-02$ & $1.25 E-02$ & 5700 \\
\hline 432 & 1165 & 2593 & & $0.00 E+00^{\circ}$ & $1.65 E-04$ & $1.27 \mathrm{E} \cdot 03$ & 1.11E-02 & 5.59E-03 & $1.95 E-02$ & $1.28 E-02$ & 8686 \\
\hline 872 & 353 & 468 & & $0.00 E+00$ & $0.00 E+00$ & 4.13E-04 & $8,64 E-03$ & $7.41 E .03$ & 2:69E^02 & $0.05 E-03$ & 9222 \\
\hline 1008 & 524 & 475 & & $0.00 E+00$ & $0.00 E+00$ & $2.27 E-04$ & $7.09 \mathrm{E}-03$ & 7.34E-03 & 2.86E-02 & $7.31 E-03$ & 10143 \\
\hline $\begin{array}{l}1298 \\
1608\end{array}$ & $\begin{array}{l}4080 \\
2279\end{array}$ & $\begin{array}{l}3808 \\
1389\end{array}$ & - & $\begin{array}{l}0.00 E+00 \\
0.00 E+00\end{array}$ & $\begin{array}{l}0.00 E+00 \\
0.00 E+00\end{array}$ & $\begin{array}{l}7.11 \text { E.05 } \\
4.89 E=05\end{array}$ & $\begin{array}{l}1.57 E .03 \\
3.12 E-04\end{array}$ & $\begin{array}{l}0.34 \mathrm{E}-03 \\
1.04 \mathrm{E} \cdot 02\end{array}$ & $\begin{array}{l}3.39 E \cdot 02 \\
3.50 E-02\end{array}$ & $\begin{array}{l}1.65 E-03 \\
3.61 E-04\end{array}$ & $\begin{array}{l}11600 \\
11876\end{array}$ \\
\hline . & & Rate Data & $\begin{array}{l}88 \mathrm{hrs} \\
168 \mathrm{hrs} \\
288 \mathrm{hrs}\end{array}$ & $\begin{array}{l}-3.07 E-08 \\
-2.05 E-08 \\
-1.53 E-08\end{array}$ & $\begin{array}{l}\text { mole/(L"hr) } \\
\text { mole/(L.hr) } \\
\text { mole/(L"hr) }\end{array}$ & & 、 & $\begin{array}{l}98 \mathrm{hrs} \\
968 \mathrm{hrs} \\
288 \mathrm{hrs}\end{array}$ & $\begin{array}{l}6.75 \mathrm{E}-05 \\
6.49 \mathrm{E}-05 \\
4.33 \mathrm{E}-05\end{array}$ & $\begin{array}{l}\text { 7.07E-05 } \\
\text { 6.00E-05 } \\
3.09 E-05\end{array}$ & $\begin{array}{l}\text { mole/(L'hr) } \\
\text { mole/(L-hr) } \\
\text { mole/(L'hr) }\end{array}$ \\
\hline
\end{tabular}

Table 4 Tost 4: $55^{\circ} \mathrm{C}$, Soluble organice and motals, Solld aludge and MST addlitvos

\begin{tabular}{|c|c|c|c|c|c|c|c|c|c|c|c|}
\hline $\begin{array}{c}\text { Reaction Time } \\
\text { (hr) }\end{array}$ & $\begin{array}{r}\text { (mg/L) } \\
\text { Bonzene }\end{array}$ & $\begin{array}{l}\text { Benzene } \\
\text { Rate } \\
\text { (ug/(L.hr)) }\end{array}$ & & $\begin{array}{c}(\mathrm{mol} / \mathrm{L}) \\
\mathrm{TPB}\end{array}$ & $\begin{array}{c}(\mathrm{mol} / \mathrm{L}) \\
3 \mathrm{~PB}\end{array}$ & $\begin{array}{c}(\mathrm{mol} / \mathrm{L}) \\
2 \mathrm{~PB}\end{array}$ & $\begin{array}{c}(\mathrm{mol} / \mathrm{L}) \\
\mathrm{PBA}\end{array}$ & $\begin{array}{c}\text { (mol/L) } \\
\text { Phenol }\end{array}$ & $\begin{array}{c}\text { Solublio Boron } \\
\text { (molen.) } \\
\text { Boron(lCP.ES) }\end{array}$ & $\begin{array}{l}\text { (mololL) } \\
\text { Boron } \\
\text { (from organica) }\end{array}$ & $\begin{array}{c}\text { Equivalent } \\
\text { NaTPB(mg/) }\end{array}$ \\
\hline 0 & 45 & - & & 4.76E-04 & 2.64E-04 & 1.42E-04 & $1.64 E-04$ & 7.23E.04 & 4.18E-03 & $1.05 \mathrm{E}-03$ & 1431 \\
\hline-96 & 72 & 281 & & $2.26 E-04$ & $1.19 E-03$ & $1.98 \mathrm{E}-03$ & 2.33E-03 & 2.64E-03 & $8.74 E-03$ & 5.73E-03 & 2980 \\
\hline 168 & 842 & 4744 & & 9.71E-05 & $1.50 \mathrm{E}-03$ & $2.88 E-03$ & 4.05E-03 & 4.46E-03 & $1.36 E-02$ & $8.62 E-03$ & 4680 \\
\hline 288 & 1252 & 1181 & & 5.64E-05 & $1.20 E-03$ & $1.83 \mathrm{E}-03$. & $4.12 E-03$ & 7.09E-03 & $1.76 \mathrm{E}-02$ & 7.20E-03 & 6027 \\
\hline 432 & 1677 & 3546 & , & $0.00 E+00$ & $4.58 \mathrm{E}-04$ & $1.00 \mathrm{E}-03$ & 2.62E-03 & $0.12 E-03$ & 2.04E-02 & $4.08 E-03$ & 6890 \\
\hline 672 & 1680 & 2403 & $\therefore$ & $0.00 E+00$ & $0.00 E+00$ & $1.11 E-04$ & $8.10 E-04$ & $1.28 E .02$ & $2.66 \mathrm{E}-02$ & $1.02 E-03$ & 8776 \\
\hline 1008 & 1031 & 978 & & $0.00 E+00$ & 6.37E-05 & $1.24 E-04$ & 3.36E-04 & $1.21 E-02$ & 2.65E-02 & 5.14E-04 & 9072 \\
\hline 1298 & 5282 & 4041 & & $0.00 E+00$ & $0.00 E+00$ & 1.64E-04, & $3.63 E-04$ & $1.49 \mathrm{E}-02$ & $2.95 \mathrm{E}-02$ & 5.17E-04 & 10096 \\
\hline 1608 & 1959 & 1100 & , & $0.00 E+00$ & $0.00 E+00$ & $1.02 E \cdot 04$ & $0.00 E+00$ & $1.47 E-02$ & $2,85 E-02$ & $-1.02 E-04$ & 9741 \\
\hline - & & Rate Data & $\begin{array}{l}98 \mathrm{hrs} \\
168 \mathrm{hrs} \\
288 \mathrm{hrs}\end{array}$ & $\begin{array}{l}-2.61 \mathrm{E}-08 \\
-2.28 \mathrm{E}-08 \\
-1.46 \mathrm{E}-08\end{array}$ & $\begin{array}{l}\text { mole/(L'hr) } \\
\text { mole/(L'hr) } \\
\text { mole/(L'hr) }\end{array}$ & & - & $\begin{array}{l}98 \mathrm{hrs} \\
168 \mathrm{hrs} \\
288 \mathrm{hrs}\end{array}$ & $\begin{array}{l}4.74 E-05 \\
5.61 E-05 \\
4.66 E-05\end{array}$ & $\begin{array}{l}4.88 \mathrm{E}-05 \\
4.51 \mathrm{E}-05 \\
2.14 \mathrm{E}-05\end{array}$ & $\begin{array}{l}\text { mole/(L'hr) } \\
\text { mole/(L'hr) } \\
\text { mole/(L'hr) }\end{array}$ \\
\hline
\end{tabular}


Table 5 Tost 5: $70^{\circ} \mathrm{C}$, Soluble organlcs and metals, Solld sludge and MST addillves

\begin{tabular}{|c|c|c|c|c|c|c|c|c|c|c|c|}
\hline $\begin{array}{l}\text { Reaction TIme } \\
\text { (hr). }\end{array}$ & $\begin{array}{l}\text { (mg/h) } \\
\text { Benzeno }\end{array}$ & $\begin{array}{c}\text { Benzene } \\
\text { Rate } \\
\text { (ug/(L"hr)) }\end{array}$ & & $\begin{array}{c}\text { (mol/l }) \\
\text { TPB. }\end{array}$ & $\begin{array}{c}\text { (mol/l) } \\
\text { 3PB }\end{array}$ & $\begin{array}{c}(\mathrm{mol} / \mathrm{L}) \\
2 \mathrm{~PB}\end{array}$ & $\underset{\text { PBA }}{(\mathrm{mol} / \mathrm{L})}$ & $\begin{array}{l}\text { (mol/L) } \\
\text { Phenol }\end{array}$ & $\begin{array}{l}\text { Soluble Boron } \\
\text { (mole/L) } \\
\text { Boron(KCP-ES) }\end{array}$ & $\begin{array}{c}\text { (mole/L) } \\
\text { Boron } \\
\text { firom organles) }\end{array}$ & $\begin{array}{l}\text { Equlvalent } \\
\text { NaTPB(mg/L) }\end{array}$ \\
\hline .0 & -45 & - & & 4.76E-04 & 2.64E-04 & $1.42 E-04$ & $1.64 E-04$ & $7.23 E-04$ & 4.18E-03 & $1.05 \mathrm{E} .03$ & 1431 \\
\hline 96 & 47 & 21 & & 9.71E-05 & $7.89 E-04$ & 2.67E-03 & $5.81 E .03$ & 4.76E-03 & 1.59E-02 & $9.38 \mathrm{E}-03$ & 5427 \\
\hline 168 & 1884 & 8756 & & $1.57 E-0.5$ & 2.81E-04 & 1.67E-03 & 6.75E-03 & $7.75 \mathrm{E}-03$ & 2.23E-02 & 8.72E-03 & 7617 \\
\hline 288 & 1471 & 4951 & & $0.00 E+00$ & $0.00 E+00$ & 4.62E-04 & 3.93E-03 & $1.04 E-02$ & 2.75E-02 & 4,39E-03 & 8412 \\
\hline 432 & 1279 & 2838 & & $0.00 E+00$ & $0.00 E+00$ & 1.38E-04 & 2.55E-03 & 1.08E-02 & 2.89E-02 & 2.69E-03 & 8882 \\
\hline 672 & 348 & 451 & ' & $0.00 E+00$ & 1.11E-04 & 2.31E-04 & $1.03 \mathrm{E}-03$ & $1.14 E-02$ & 3.59E-02 & 1.37E-03 & 12277 \\
\hline 1008 & 398 & 350 & & $0.00 E+00$ & $0.00 E+00$ & $8.44 E-05$ & 9.92E-0.4 & 1.29E-02 & $3.72 E-02$ & $1.08 E-03$ & 12725 \\
\hline 1296 & 3338 & 2641 & & $0.00 E+00$ & $0.00 E+00$ & 5.78E-05 & 6.81E-04 & $1.48 E-02$ & $4.18 E-02$ & $7.38 \mathrm{E}-04$ & 14305 \\
\hline \multirow[t]{2}{*}{1608} & 4423 & 2723 & & $0.00 E+00$ & $0.00 E+00$ & 3.11E-05 & 7.87E-04 & 1.62E.02 & 4.33E-02 & $8.18 E-04$ & 14813 \\
\hline & * & Rato Data & $\begin{array}{l}96 \text { hrs } \\
188 \text { hrs } \\
288 \text { hrs } \\
\end{array}$ & $\begin{array}{l}-3.85 \mathrm{E}-0 \theta \\
-2.74 \mathrm{E}-06 \\
-1.65 \mathrm{E}-0 \theta \\
\end{array}$ & $\begin{array}{l}\text { mole/(L"hr) } \\
\text { mole/(L"hr) } \\
\text { mole/(L"hr) } \\
\end{array}$ & . & & . & $\begin{array}{l}1.22 E-04 \\
1.08 E-04 \\
8.10 E-05 \\
\end{array}$ & $\begin{array}{l}8.68 \mathrm{E}-05 \\
4.57 \mathrm{E}-05 \\
1.16 \mathrm{E}-05 \\
\end{array}$ & $\begin{array}{l}\text { mole/(L'hr) } \\
\text { mole/(L"hr) } \\
\text { mole/(L'hr) }\end{array}$ \\
\hline
\end{tabular}

Table 6 Tast 6: $70^{\circ} \mathrm{C}$, Soluble organles and motals, Solld sludge and MST addilives

\begin{tabular}{|c|c|c|c|c|c|c|c|c|c|c|c|c|}
\hline $\begin{array}{r}\text { Reaction } \\
\text { (hr) }\end{array}$ & nime & $\begin{array}{c}\text { (mg/L) } \\
\text { Benzene }\end{array}$ & $\begin{array}{l}\text { Benzene } \\
\text { Rate } \\
\text { (ug/(L"hr)) }\end{array}$ & & $\begin{array}{c}\text { (mol/L) } \\
\text { TPB }\end{array}$ & $\begin{array}{c}(\mathrm{mol} / \mathrm{L}) \\
3 \mathrm{~PB}\end{array}$ & $\begin{array}{c}(\mathrm{mol} / \mathrm{L}) \\
2 \mathrm{~PB}\end{array}$ & $\begin{array}{c}(\mathrm{mol} / \mathrm{L}) \\
\mathrm{PBA}\end{array}$ & $\begin{array}{l}\text { (mol/L) } \\
\text { Phonol }\end{array}$ & $\begin{array}{c}\text { Soluble Boron } \\
\text { (mole/L) } \\
\text { Boron(ICP-ES). }\end{array}$ & $\begin{array}{l}\text { (mole/L) } \\
\text { Boron } \\
\text { (from organic }\end{array}$ & $\begin{array}{l}\text { Equivalent } \\
\text { NaTPB(mg/L) } \\
\text { cs) }\end{array}$ \\
\hline 0 & & 45 & $\ldots$ & & $4.76 \mathrm{E}-04$ & 2.64E-04 & $1.42 E-04$ & $1.64 E-04$ & 7.23E-04 & 4.18E-03 & $1.05 E-03$ & 1431 \\
\hline $\begin{array}{c}06 \\
168\end{array}$ & & $\begin{array}{c}20 \\
494\end{array}$ & $\begin{array}{c}0 \\
2873\end{array}$ & & $\begin{array}{l}2.69 E-04 \\
9.08 E-05\end{array}$ & $\begin{array}{l}6.63 E-04 \\
8.33 E-04\end{array}$ & $\begin{array}{l}\text { 6.02E-04 } \\
2.54 E-03\end{array}$ & $\begin{array}{r}6.48 \mathrm{E}-04 \\
3.56 \mathrm{E}-03\end{array}$ & $\begin{array}{l}1.60 E-03 \\
4.18 E-03\end{array}$ & $\begin{array}{l}6.08 E-03 \\
1.22 E-02\end{array}$ & 1.97E-03 & 2080 \\
\hline 288 & & $1296^{\circ}$ & 4344 & & 1.67E-05 & 4.67E-04 & 1.00 E-03 & 2.35E-03 & 6.53E-03 & 1.76E-02 & $3.84 E .03$ & 6038 \\
\hline 432 & . & 1653 & 3481 & & $0.00 E+00$ & 1.24E-04 & $3,0,1 E-04$ & 1.33E-03 & 9.05E-03 & 2.27E-02 & $1.84 \mathrm{E}-03$ & 7782 \\
\hline 672 & & 1280 & 1808 & & $0.00 \mathrm{E}+00$ & 4.64E-05 & $2.49 E-04$ & 4.61E.04 & 1.16E-02 & 2.70E-02 & 7.45E-04 & 9256 \\
\hline 1008 & - & 891 & 839 & & $0.00 E+00$ & $0.00 E+00$ & 2.69E-04 & 1.08E-03 & $1.28 \mathrm{E}-02$ & 2.98E-02 & $1.35 E-03$ & 10208 \\
\hline $\begin{array}{l}1296 \\
1808\end{array}$ & & $\begin{array}{l}4427 \\
3114\end{array}$ & $\begin{array}{l}3381 \\
1909\end{array}$ & ' & $\begin{array}{l}0.00 E+00 \\
0.00 E+00\end{array}$ & $\begin{array}{l}0.00 E+00 \\
0.00 E+00\end{array}$ & $\begin{array}{l}\text { 8.88E-05 } \\
3.11 E-05\end{array}$ & $\begin{array}{l}7.79 E-04 \\
2.05 E-04\end{array}$ & $\begin{array}{l}1.45 E-02 \\
1.67 E-02\end{array}$ & $\begin{array}{l}3.46 \mathrm{E}-02 \\
3.46 \mathrm{E}-02\end{array}$ & $\begin{array}{l}8.68 E-04 \\
2.36 E-04\end{array}$ & $\begin{array}{l}11800 \\
11837\end{array}$ \\
\hline & & & Rate Data & $\begin{array}{l}98 \text { hrs } \\
168 \text { hrs } \\
288 \text { hrs } \\
\end{array}$ & $\begin{array}{l}-2.16 \text { E-06 } \\
-2.29 E-08 \\
-1.60 \text { E-08 }\end{array}$ & $\begin{array}{l}\text { molo/(L"hr) } \\
\text { mole/(L"hr) } \\
\text { mole/(L-hr) }\end{array}$ & & & & $\begin{array}{l}1.97 \mathrm{E}-05 \\
4.80 \mathrm{E}-05 \\
4.67 \mathrm{E}-05 \\
\end{array}$ & $\begin{array}{l}9.65 E-06 \\
3.62 E-05 \\
9.68 E-06\end{array}$ & $\begin{array}{l}\text { mole/(L'hr) } \\
\text { molo/(L'hr) } \\
\text { mole/(L'hr) }\end{array}$ \\
\hline
\end{tabular}


Table 7 Tost $7: 55^{\circ} \mathrm{C}$, Soluble organics and motals addltives

\begin{tabular}{|c|c|c|c|c|c|c|c|c|c|c|c|}
\hline $\begin{array}{l}\text { Reaction Time } \\
\text { (hi) }\end{array}$ & $\begin{array}{l}\text { (mg/h) } \\
\text { Benzeno }\end{array}$ & $\begin{array}{c}\text { Benzene } \\
\text { Rate } \\
\text { (ug/(L"hr)) }\end{array}$ & & $\underset{\text { TPB }}{(\mathrm{mol} / \mathrm{L})}$ & $\begin{array}{c}\text { (mol/L) } \\
\text { 3PB }\end{array}$ & $\begin{array}{c}(\mathrm{mol} / \mathrm{L}) \\
2 \mathrm{~PB}\end{array}$ & $\begin{array}{c}\text { (mol/L) } \\
\text { PBA }\end{array}$ & $\begin{array}{l}\text { (moln) } \\
\text { Phond }\end{array}$ & $\begin{array}{c}\text { Soluble Boron } \\
\text { (mole/t.) } \\
\text { Boron(lCP.ES) }\end{array}$ & $\begin{array}{l}\text { (molent) } \\
\text { Boron } \\
\text { (from organics) }\end{array}$ & $\begin{array}{l}\text { Equivalont } \\
\text { NaTPB(mg/L) } \\
\text { s) }\end{array}$ \\
\hline 0 & 45 & - & & $4.76 \mathrm{E}-04$ & 2.84E-04 & 1.42E-04 & 1.64E-04 & $7.23 E-04$ & 4.18E-03 & $1.05 E-03$ & 1431 \\
\hline 96 & 118 & 760 & & $2.57 E-04$ & 2.13E-03 & $2.44 E-03$ & 1.76E-03 & $4.18 \mathrm{E}-03$ & 1.05E.02 & $6.59 E-03$ & 3607 \\
\hline 168 & 838 & 5315 & 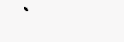 & $1.79 E-04$ & 2.83E-03 & $3.01 E .03$ & 2.55E-03 & 5.57E-03 & 1.17E-02 & 8.57E-03 & 3989 \\
\hline 288 & 1502 & 5059 & & $1.13 E-04$ & 3.14E-03 & 2.95E-03 & $3.30 E-03$ & 7.73E-03 & 1.33E-02 & $8.50 E-03$ & 4555 \\
\hline .432 & 1726 & 3881 & & $7.20 \mathrm{E}-05$ & $2.81 E-03$ & 2.42E-03 & $3.58 E-03$ & 9.82E-03 & $1.77 \mathrm{E}-02$ & $8.87 E-03$ & 6073 \\
\hline 872 & 2568 & 3756 & & 2.82E.05 & 1.86 E-03 & 1.77E-03 & $3.09 E-03$ & $1.34 E-02$ & 2.42E-02 & $6.75 E-03$ & 8284 \\
\hline 1008 & 1874 & 1814 & & $0.00 E+00$ & $7.68 \mathrm{E}-04$ & 1.52E-03 & $1.88 E-03$ & 1.58E-02 & 2.48E-02 & 4.17E-03 & 8474 \\
\hline 1296 & 4635 & 3542 & & $0.00 E+00$ & $4.21 E-04$ & 3.02E-04 & $3.85 E-04$ & $1.91 E-02$ & 2.85E-02 & 1.11 E.03 & 9748 \\
\hline \multirow[t]{2}{*}{1608} & 3081 & -1876 & & $0.00 E+00$ & 2.89E-04 & $0.00 E+00$ & $1.64 E-04$ & $1.98 \mathrm{E}-02$ & $2.66 \mathrm{E}-02$ & 4.53E-04 & 8089 \\
\hline & & Rato Data & $\begin{array}{l}98 \mathrm{hrs} \\
168 \mathrm{hrs} \\
288 \mathrm{hrs}\end{array}$ & $\begin{array}{l}-2.28 \mathrm{E}-08 \\
-1.77 \mathrm{E}-08 \\
-1.2 B \mathrm{~B}-08\end{array}$ & $\begin{array}{l}\text { molo/(L"hr) } \\
\text { molo/(L."hr) } \\
\text { molo/(L'hr) }\end{array}$ & : & & & $\begin{array}{l}6.62 E-05 \\
4.45 E-05 \\
3.17 E-05\end{array}$ & $\begin{array}{l}\text { 5.77E-05 } \\
4.48 E-05 \\
2.83 E-05\end{array}$ & $\begin{array}{l}\text { molel(L'hr) } \\
\text { mole/(L"hr) } \\
\text { molel(L"hr) }\end{array}$ \\
\hline
\end{tabular}

Table 8 Test 8: $55^{\circ} \mathrm{C}$, Soluble organlcs and metale additives, Solld sludgo Addlituos

Reaction
(hr)
0
96
168
288
432
872
1008
1298
1608

\begin{tabular}{c} 
Bonzene \\
Rate \\
(ug/(L'he)) \\
583 \\
7054 \\
5684 \\
2551 \\
1100 \\
701 \\
1100 \\
2435 \\
\hline
\end{tabular}

Rato Data

\begin{tabular}{|c|c|c|}
\hline (mol/h) & (mollls) & $(\mathrm{mol} / \mathrm{ll})$ \\
\hline $\begin{array}{c}\text { TPB } \\
4.76 \mathrm{E}-04\end{array}$ & $\begin{array}{c}3 P B \\
2.64 E-04 \\
145-03\end{array}$ & $\begin{array}{c}\text { 2PB } \\
1.42 E .04 \\
4.09 E .03\end{array}$ \\
\hline $\begin{array}{l}1.72 E-04 \\
6.95 E-05 .\end{array}$ & $\begin{array}{l}1.45 E-03 \\
1.23 E-03\end{array}$ & 4.09E-03 \\
\hline $9 ., 10 \mathrm{E} \cdot 06$ & 2.80E-04 & 3.81E.03 \\
\hline $\begin{array}{l}0.00 E+00 \\
0.00 E+00\end{array}$ & $\begin{array}{l}3.72 E-05 \\
0.00 E+00\end{array}$ & $\begin{array}{l}\text { 9.64E-04 } \\
2.04 E-04\end{array}$ \\
\hline $0.00 E+00$ & $0.00 E+00$ & 1.11E.04 \\
\hline $0.00 E+00$ & $0.00 E+00$ & 6.66E-06 \\
\hline $0.00 E+00$ & $0.00 E+00$ & 4.89E-05 \\
\hline
\end{tabular}

N

\begin{tabular}{|c|c|c|c|c|}
\hline$\underset{\text { PBA }}{\text { (molll). }}$ & $\begin{array}{l}\text { (mol/l) } \\
\text { Phenol }\end{array}$ & $\begin{array}{c}\text { Soluble Boron } \\
\text { (molo/L) } \\
\text { Boron(KCP.ES) }\end{array}$ & $\begin{array}{l}\text { (molen). } \\
\text { Boron } \\
\text { (from organles }\end{array}$ & $\begin{array}{l}\text { Equlvalont } \\
\text { NaTPB(mg/L) } \\
\text { g) }\end{array}$ \\
\hline $1.64 E-04$ & 7.23E-04 & 4.18E-03 & $1.05 E-03$ & 1431 \\
\hline $3.48 E-03$ & $3.00 E-03$ & 1.20E-02 & $8.21 E-03$ & 1111 \\
\hline 6.93E-03 - & 6.27E-03 & $1.67 E-02$ & 1.22E-02 & 5706 \\
\hline 9.73E-03 & 6.08E-03 & 1.98E-02 & 1.38E-02 & 6785 \\
\hline $1.16 \mathrm{E}-02$ & 7.23E-03 & 2.15E-02 & 1.26E-02 & 7366 \\
\hline $8.04 E-03$ & $8.73 E-03$ & $2.85 E-02$ & 8.24E-03 & 10104 \\
\hline $4.67 E-03$ & 9.52E-03 & $3.26 \mathrm{E}-02$ & $4.79 \mathrm{E}-03$ & 19168 \\
\hline $9.10 E-04$ & 1.12E-02 & $3.71 E-02$ & 9.85E.04 & 12681 \\
\hline \multirow[t]{2}{*}{ 6.25E-04 } & $1.20 \mathrm{E}-02$ & $3.61 E \cdot 02$ & 6.74E-04 & 12026 \\
\hline & & $\begin{array}{l}8.16 E-05 \\
7.44 E-05 \\
5.43 E-05 \\
\end{array}$ & $\begin{array}{l}\text { 8.60E-05 } \\
6.65 E-05 \\
4.44 \text { E-05. }\end{array}$ & $\begin{array}{l}\text { mole/(L"hp) } \\
\text { mole/(L"hr) } \\
\text { mole/(L"hp) }\end{array}$ \\
\hline
\end{tabular}


Tablo 9 Test 9: $70^{\circ} \mathrm{C}$; Soluble organles and motals additivos

\begin{tabular}{|c|c|c|c|c|c|c|c|c|c|c|c|}
\hline $\begin{array}{l}\text { Reaction Time } \\
\text { (hi) }\end{array}$ & $\begin{array}{r}\text { (mg/L) } \\
\text { Benzene }\end{array}$ & $\begin{array}{c}\text { Benzene } \\
\text { Rate } \\
\text { (ug/(L-hr)) }\end{array}$ & & $\begin{array}{c}\text { (mol/L) } \\
\text { TPB. }\end{array}$ & $\begin{array}{c}\text { (mol/L) } \\
\text { 3PB }\end{array}$ & $\begin{array}{c}(\mathrm{mol} / \mathrm{L}) \\
2 P B\end{array}$ & $\begin{array}{c}(\mathrm{mol} / \mathrm{L}) \\
\mathrm{PBA}\end{array}$ & $\underset{\text { Phenol }}{(\mathrm{mol} / \mathrm{L})}$ & $\begin{array}{l}\text { Soluble Boron } \\
\text { (mole/L) } \\
\text { Boron/(CP.ES) }\end{array}$ & $\begin{array}{l}\text { (molo/L) } \\
\text { (mol/L) } \\
\text { on(from organ }\end{array}$ & $\begin{array}{l}\text { Equivalent } \\
\text { NaTPB(mg/L) } \\
\text { las) }\end{array}$ \\
\hline 0 & 45 & -- & & 4.76E-04 & $2.64 E-04$ & 1.42E-04. & $1,64 E-04$ & 7.23E-04 & $4.18 E-03$ & $1.05 \mathrm{E}-03$ & 1431 \\
\hline 96 & 67 & 229 & . & 2.29E-04 & 1.89E-03 & $1.43 E-03$ & $0.10 E-04$ & 2.68E-03 & 7.81E-03 & $4.46 \mathrm{E}-03$ & 2673 \\
\hline 168 & 1110 & 6339 & & 1.91E-04 & 2.77E-03 & 1.60E-03 & $1.57 \mathrm{E}-03$ & 4.41E-03 & $1.05 E-02$ & $6.14 E-03$ & 3594 \\
\hline 288 & 1763 & 5886 & & 1.25E-04 & 3.25E-03 & 1.54E-03 & $1.88 E-03$ & 6.02E.03 & 1.27E-02 & $6.79 E-03$ & 4342 \\
\hline 432 & 2100 & 4757 & & 6.64E-05 & 2.73E-03 & $1.63 \mathrm{E}-03$ & $2.03 E-03$ & 8.32E-03 & 1.63E-02 & $6.45 E-03$ & 5569 \\
\hline 672 & 2496 & 3647 & & $0.00 E+00$ & $1.07 E-03$ & $1.86 \mathrm{E}-0,3$ & 2.22E-03 & $1.06 \mathrm{E}-02$ & $2.36 \mathrm{E}-02$ & 5.15E-03 & 8082 \\
\hline 1008 & 1299 & .1244 & & $0.00 E+00$ & 1.73E-04 & $0.46 E-04$ & $1.60 \mathrm{E}-03$ & 1.24E-02 & 2.65E-02 & 2.72E-03 & 9066 \\
\hline 1296 & 6843 & 4551 & & $0.00 E+00$ & 5.37E-05 & 1.85E-04 & $0.00 E+00$ & 1.47E-02 & 3.12E-02 & $2.48 E-04$ & 10687 \\
\hline 1608 & 3606 & 2215 & $\cdot$ & $0.00 E+00$ & $0.00 E+00$ & 1.51E-04 & $0.00 E+00$ & $1.51 E-02$ & 2.84E-02 & 1.51E-04 & 10056 \\
\hline ' & & Rate Data & $\begin{array}{l}98 \text { hrs } \\
168 \text { hrs } \\
288 \text { hrs } \\
\end{array}$ & $\begin{array}{l}-2.68 \mathrm{E}-08 \\
-1.70 \mathrm{E}-08 \\
-1.22 \mathrm{E}-0 \mathrm{~B} \\
\end{array}$ & $\begin{array}{l}\text { mole/(L"hr) } \\
\text { mole/(L"hr) } \\
\text { mole/(L"hr) }\end{array}$ & • & , & & $\begin{array}{l}3.78 E-05 \\
3.76 E-05 \\
2.95 E-05 \\
\end{array}$ & $\begin{array}{l}3.56 \mathrm{E}-05 \\
3.03 \mathrm{E}-05 \\
1.09 \mathrm{E}-05 \\
\end{array}$ & $\begin{array}{l}\text { mole/(L"hr) } \\
\text { mole/(L-hr) } \\
\text { mole/(L"hr) }\end{array}$ \\
\hline
\end{tabular}

Tabli 10 Test $10: 70^{\circ} \mathrm{C}$, Soluble organics and motals, Solld sludge additivas

\begin{tabular}{|c|c|c|c|c|c|c|c|c|c|c|c|}
\hline $\begin{array}{c}\text { Reaction Time } \\
\text { (hr) }\end{array}$ & $(m g / L)$ & $\begin{array}{l}\text { Benzeno } \\
\text { Rate }\end{array}$ & . & $(\mathrm{mol} / \mathrm{L})$ & $(\mathrm{mol} / \mathrm{L})$ & (mol/h) & (mol/L) & (mol/L) & $\begin{array}{c}\text { Soluble Boton } \\
\text { (mole/L) }\end{array}$ & $\begin{array}{c}\text { (mole/L) } \\
\text { Boron }\end{array}$ & $\begin{array}{l}\text { Equivalent } \\
\text { NaTPB(mg/n) }\end{array}$ \\
\hline ' & Benzene & $(u g /(L \circ h r))$ & & TPB. & 3PB & 2PB & PBA & Phenol & Boron(ICP-ES) & (from organics) & \\
\hline 0 & 45 & - & & $4.76 E-04$ & 2.64E-04 & $1.42 E \cdot 04$ & 1.64E-04 & 7.23E-04 & $4.18 E .03$ & 1.06E-03 & 1431 \\
\hline 96 & 571 & 5479 & & $2.38 E-04$ & 7.14E-04， & $1.44 E-03$ & 2.56E.03 & $3.69 \mathrm{E} \cdot 03$ & 1.18E-02 & 4.95E-03 & 4042 \\
\hline 168 & 2723 & 15040 & & 4.38E-05 & 8.61E.04 & 3.13E-03 & $5.18 E .03$ & 6.51E-03 & 1.99E-02 & 9.05E-03 & 6815 \\
\hline 288 & 2331 & 7938 & & $0.00 E+00$ & $7.85 E-05$ & 1.34E-03 & $6,99 E-03$ & 7.10E-03 & 2.52E-02 & 6.79E.03 & 8814 \\
\hline 432 & 827 & 1810 & & $0.00 E+00$ & $0.00 E+00$ & $3.78 E-04$ & 6.77E-03 & 7.98E-03 & 2.86E-02 & 6.14E-03 & 9782 \\
\hline 672 & 917 & 1298 & & $0.00 E+00$ & $0.00 E+00$ & 1.55E-04 & 2.06E-03 & 8.70E-03 & 3.51E.02 & 3.12E-03 & 12001 \\
\hline 1008 & 581 & 642 & & $0.00 E+00$ & $0.00 E+00$ & 6.33E:05 & $9.78 E \cdot 03$ & $9.46 E-03$ & 3.89E-02 & 1.83E-03 & 13287 \\
\hline 1286 & - $\quad 6994$ & 4590 & r & $0.00 E+00$ & $0.00 E+00$ & 2.67E-05 & 1.18E-03 & 1.03E-02 & 4.46E.02 & 1.21E-03 & 16227 \\
\hline 1608 & 3040 & 2428 & . & $0.00 E+00$ & $0.00 E+00$ & $0.00 E+00$ & 8.12E.04 & 1.06E-02 & 4.41E-02 & $8.12 E-04$ & 15103 \\
\hline & - & Rato Data & $\begin{array}{l}96 \mathrm{hrs} \\
168 \mathrm{hrs} \\
288 \mathrm{hrs}\end{array}$ & $\begin{array}{l}-2.48 E-08 \\
-2.67 E-06 \\
-1.22 E-0 B \\
\end{array}$ & $\begin{array}{l}\text { mole/(L"hr) } \\
\text { molel(L"hr) } \\
\text { mole/(L"hr) }\end{array}$ & & & & $\begin{array}{l}7.95 E-05 \\
9.36 E-05 \\
7.29 E-05\end{array}$ & $\begin{array}{l}1.07 E=05 \\
4.77 E-05 \\
1.99 E-05\end{array}$ & $\begin{array}{l}\text { mole/(L"hr) } \\
\text { mole/(L"hr) } \\
\text { mole/(L"hr) }\end{array}$ \\
\hline
\end{tabular}


Tablo.11 Test 11: $55^{\circ} \mathrm{C}$, No Addltives

\begin{tabular}{|c|c|c|c|c|c|c|c|c|c|c|c|c|}
\hline $\begin{array}{l}\text { Reaction Tme } \\
\text { (hr) }\end{array}$ & $\begin{array}{c}\text { (mg/L) } \\
\text { Benzeno }\end{array}$ & & $\begin{array}{l}\text { Benzene } \\
\text { Rate } \\
\text { (ug/(L."hr)) }\end{array}$ & & $\begin{array}{c}\text { (mol/L) } \\
\text { TPB. }\end{array}$ & $\begin{array}{c}\text { (mol/L) } \\
3 P B\end{array}$ & $\begin{array}{c}(\mathrm{mol} / \mathrm{L}) \\
2 P B\end{array}$ & $\begin{array}{c}(\mathrm{mol} / \mathrm{L}) \\
\mathrm{PBA}\end{array}$ & $\begin{array}{c}\text { (mol/L) } \\
\text { Phend }\end{array}$ & $\begin{array}{c}\text { Soluble Boron } \\
\text { (mole/L) } \\
\text { Boron(ICP-ES) }\end{array}$ & $\begin{array}{c}\text { (mole/L) } \\
\text { Boron } \\
\text { (from organles) }\end{array}$ & $\begin{array}{l}\text { Equlvalent } \\
\mathrm{NaTPB}(\mathrm{mg} / \mathrm{L})\end{array}$ \\
\hline 0. & 1 & & $\cdot \quad-$ & . & 4.76E-04 & $0.00 E+00$ & $0.00 E+00$ & $0.00 E+00$ & $0.00 E+00$ & $3.71 E-03$ & $4.76 \mathrm{E}-04$ & 1268 \\
\hline 96 & 2 & & 10 & & $2.00 E-04$ & $0.00 E+00$ & $0.00 E+00$ & $0.00 E+00$ & $0.00 E+00$ & $2.92 E-03$ & 2.00E-04 & 999 \\
\hline 168 & 6 & & 24 & & $2.07 E-04$ & $0.00 E+00$ & $0.00 E+00$ & $0.00 E+00$ & $0.00 E+00$ & 2.59E-03 & 2.07E-04 & 885 \\
\hline 288 & 2 & & 3 & & 2.04E-04 & $0.00 E+00$ & $0.00 E+00$ & $0.00 E+00$ & $0.00 E+00$ & 2.67E-03 & 2.04E-04 & 815 \\
\hline 432 & 1 & & 0 & & $1.82 \mathrm{E}-04$ & $0.00 E+00$ & $0.00 E+00$ & $0.00 E+00$ & $0.00 E+00$ & $2.22 E-03$ & $1.82 E-04$ & 759 \\
\hline 672 & 87 & - & 128 & - & $1.75 \mathrm{E}-04$ & $0.00 E+00$ & $0.00 E+00$ & $0.00 E+00$ & $0.00 E+00$ & $2.06 E-03$ & $1.75 \mathrm{E}-04$ & 704 \\
\hline 1008 & 8. & & 7 & & 1.82E-04 & $0.00 E+00$ & $0.00 E+00$ & $0.00 E+00$ & $0.00 E+00$ & $2.18 E-03$ & 1.82E-04 & 745 \\
\hline 1296 & 16 & & 12 & & 1.72E-04 & $0.00 E+00$ & $0.00 E+00$ & $0.00 E+00$ & $0.00 E+00$ & $2.60 E-03$ & $1.72 \mathrm{E}-04^{-}$ & 888 \\
\hline 1608 & $\theta$ & & 5 & & $1.66 \mathrm{E}-04$ & $0.00 E+00$ & $0.00 E+00$ & $0.00 \mathrm{E}+00$ & $0.00 E+00$ & $1.15 \mathrm{E}-03$ & $1.66 \mathrm{E}-04$ & 394 \\
\hline & & . & Rato Data & $\begin{array}{l}98 \mathrm{hrs} \\
168 \mathrm{hrs} \\
288 \mathrm{hrs}\end{array}$ & $\begin{array}{l}-2.87 E-06 \\
-1.60 E-06 \\
-8.46 E-07\end{array}$ & $\begin{array}{l}\text { mole/(L"hr) } \\
\text { mole/(L"hr) } \\
\text { mole/(L"hr) }\end{array}$ & & & & $\begin{array}{l}-8.18 E-08 \\
-6.68 E-0 B \\
-3.68 E-0 B \\
\end{array}$ & $\begin{array}{l}-2.87 \mathrm{E}-06 \\
-1.60 \mathrm{E} \cdot 06 \\
-9.46 \mathrm{E} \cdot 07\end{array}$ & $\begin{array}{l}\text { mole/(L"hr) } \\
\text { mole/(L-hr) } \\
\text { mole/(L-hr) }\end{array}$ \\
\hline
\end{tabular}

Table 12 Test $12: 70^{\circ} \mathrm{C}$, No Additleas

\begin{tabular}{|c|c|c|c|c|c|c|c|c|c|c|c|}
\hline $\begin{array}{l}\text { Reaction Time } \\
\text { (hi) }\end{array}$ & $\begin{array}{l}\text { (mg/L) } \\
\text { Benzeno }\end{array}$ & $\begin{array}{l}\text { Benzeno } \\
\text { Rato } \\
\text { (ug/(L“hr)) }\end{array}$ & & $\begin{array}{c}(\mathrm{mol} / \mathrm{L}) \\
\text { TPB }\end{array}$ & $\begin{array}{c}(\mathrm{mol} / \mathrm{L}) \\
3 \mathrm{~PB}\end{array}$ & $\begin{array}{c}\text { (mol/L) } \\
\text { 2PB. }\end{array}$ & $\begin{array}{c}(\mathrm{mol} / \mathrm{L}) \\
\mathrm{PBA}\end{array}$ & $\begin{array}{l}\text { (mol/L) } \\
\text { Phond }\end{array}$ & $\begin{array}{l}\text { Soluble Boron } \\
\text { (mole/L) } \\
\text { Boron(lCP-ES) }\end{array}$ & $\begin{array}{l}\text { (mole/L) } \\
\text { Boron } \\
\text { (from organlas) }\end{array}$ & $\begin{array}{l}\text { Equlvalent } \\
\operatorname{NaTPB}(\mathrm{m} g / \mathrm{L})\end{array}$ \\
\hline $\begin{array}{c}0 \\
96\end{array}$ & $\begin{array}{l}1 \\
9\end{array}$ & $\overline{83}$ & & $\begin{array}{l}4.78 E-04 \\
2.35 E-04\end{array}$ & $\begin{array}{l}0.00 E+00 \\
0.00 E+00\end{array}$ & $\begin{array}{l}0.00 E+00 \\
0.00 E+00\end{array}$ & $\begin{array}{l}0.00 E+00 \\
0.00 E+00\end{array}$ & $\begin{array}{l}0.00 E+00 \\
0.00 E+00\end{array}$ & $\begin{array}{l}\text { 3.71E.03 } \\
2.76 \text { E-03 }\end{array}$ & $\begin{array}{l}4.76 E-04 \\
2.35 E-04\end{array}$ & $\begin{array}{c}1268 \\
844\end{array}$ \\
\hline 168 & 4 & 18 & & 2.00E-04 & $0.00 E+00$ & $0.00 E+00$ & $0.00 E+00$ & $0.00 E+00$ & 2.34E-03 & 2.00E-04 & 802 \\
\hline 288 & 1 & 0 & & 2.00E-04 & $0.00 E+00$ & $0.00 E+00$ & $0.00 \mathrm{E}+00$ & $0.00 E+00$ & 2.62E-03 & 2.00E-04 & 863 \\
\hline 432 & 1 & 0 & & $1.82 E-04$ & $0.00 \mathrm{E}+00$ & $0.00 E+00$ & $0.00 E+00$ & $0.00 E+00$ & $1.07 E-03$ & $1.82 \mathrm{E}-04$ & 673 \\
\hline 672 & 20 & 28 & & $1.94 \mathrm{E}-04$ & $0,00 \mathrm{E}+00$ & $0.00 E+00$ & $0.00 E+00$ & $0.00 E+00$ & 2.04E-03 & 1.94E-O4 & 689 \\
\hline 1008 & 4 & .3 & & 1.75E-04 & $0.00 E+00$ & $0.00 E+00$ & $0.00 E+00$ & $0.00 E+00$ & $1.88 \mathrm{E}-03$ & $1.75 \mathrm{E}-04$ & 644 \\
\hline 1296 & 8 & 5 & & 1.82E-04 & $0.00 E+00$ & $0.00 E+00$ & $0.00 E+00$ & $0.00 E+00$ & $2,40 E-03$ & $1.82 \mathrm{E}-04$ & $823^{-}$ \\
\hline 1608 & 6 & 3 & & $1.66 \mathrm{E} \cdot 04$ & $0.00 E+00$ & $0: 00 E+00$ & $0.00 E+00$ & $0.00 E+00$ & $1.14 E-03$ & 1.66 E.04 & 389 \\
\hline$\because$ & & Rato Data & $\begin{array}{l}88 \text { hrs } \\
168 \text { hrs } \\
288 \text { hrs }\end{array}$ & $\begin{array}{l}-2.61 \text { E.06 } \\
-1.64 E-08 \\
-9.57 E-07\end{array}$ & $\begin{array}{l}\text { mole/(L"hr) } \\
\text { mole/(L*hr) } \\
\text { mole/(L"hr) }\end{array}$ & t & & & $\begin{array}{l}-9.86 \mathrm{E}-06 \\
-8.10 \mathrm{E}-06 \\
-4.11 \mathrm{E}-06 \\
\end{array}$ & $\begin{array}{l}-2.61 E \cdot 06 \\
-1.64 E-08 \\
-9.67 E-07 \\
\end{array}$ & $\begin{array}{l}\text { mole/(L"hr) } \\
\text { mole/(L"hr) } \\
\text { mole/(L" } \mathrm{hr})\end{array}$ \\
\hline
\end{tabular}


Table 13. Preliminary Kinetics Data for (K,Na) TPB Slurries Tested at 40 to $70^{\circ} \mathrm{C}$.

\begin{tabular}{|c|c|c|c|c|c|c|}
\hline $\begin{array}{l}\text { Test } \\
\text {. }\end{array}$ & $\begin{array}{l}\text { Terrp. } \\
\left({ }^{\circ} \mathrm{C}\right)\end{array}$ & Additives & $\begin{array}{l}\text { Cumulative } \\
\text { Boron Rate } \\
\left(\text { mole/ } /\left(L^{\star} h r\right)\right) \\
\left(x 10^{-5}\right)\end{array}$ & $\begin{array}{l}\text { Pseudo first } \\
\text { Order Rate } \\
\text { Constant, } k^{\prime} \\
\left(h r^{-1}\right)\end{array}$ & 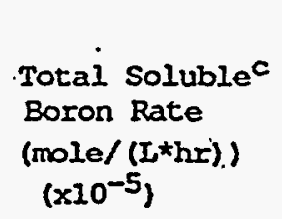 & $\begin{array}{l}\text { Pseudo first } \\
\text { Order Rate } \\
\text { Constant, } k^{\prime} \\
\left(h r^{-1}\right)\end{array}$ \\
\hline $\begin{array}{l}1 . \\
2\end{array}$ & $\begin{array}{l}40 \\
40\end{array}$ & $\begin{array}{l}d \\
d\end{array}$ & $\begin{array}{l}3.85 \\
1.56\end{array}$ & $\begin{array}{l}0.0808 \\
0.0327\end{array}$ & $\begin{array}{l}3.08 \\
0.92\end{array}$ & $\begin{array}{l}0.0579 \\
0.0199\end{array}$ \\
\hline $\begin{array}{l}3 \\
4\end{array}$ & $\begin{array}{l}55 \\
55\end{array}$ & $\begin{array}{l}d \\
d\end{array}$ & $\begin{array}{l}6.00 \\
4.51\end{array}$ & $\begin{array}{l}0.1260 \\
0.0946\end{array}$ & $\begin{array}{l}5.49 \\
5.61\end{array}$ & $\begin{array}{l}0.1003 \\
0.1025\end{array}$ \\
\hline $\begin{array}{l}5 \\
6\end{array}$ & $\begin{array}{l}70 \\
70\end{array}$ & $\begin{array}{l}d \\
d\end{array}$ & $\begin{array}{l}4.57 \\
3.62\end{array}$ & $\begin{array}{l}0.0959 \\
0.0759\end{array}$ & $\begin{array}{r}10.80 \\
4.80\end{array}$ & $\begin{array}{l}0.1930 \\
0.0882\end{array}$ \\
\hline $\begin{array}{l}7 \\
8 \\
9 \\
10\end{array}$ & $\begin{array}{l}55 \\
55 \\
70 \\
70\end{array}$ & $\begin{array}{l}e \\
f \\
e \\
f\end{array}$ & $\begin{array}{l}4.48 \\
6.65 \\
3.03 \\
4.77\end{array}$ & $\begin{array}{l}0.0941 \\
0.1396 \\
0.0637 \\
0.1001\end{array}$ & $\begin{array}{l}4.45 \\
7.44 \\
3.76 \\
9.36\end{array}$ & $\begin{array}{l}0.0820 \\
0.1345 \\
0.0699 \\
0.1685\end{array}$ \\
\hline 119 & 55 & h & -0.16 & $<0.0001$ & -0.66 & $<0.0001$ \\
\hline $12^{9}$ & 70 & $\mathbf{h}$ & -0.16 & $<0.0001$ & -0.81 & $<0: 0001$ \\
\hline
\end{tabular}

a Cumulative boron initial production rates calculated from boron produced in first 168 hours as boron-containing organics from HPLC analyses of the slurry filtrates. Note rates are based on only two data points (time $=0$ and $168 \mathrm{hr}$ ).

b. Obtained from equation, Rate $=k$ [TPB $^{-}$[Catalyst $^{n}=k^{\prime}[$ TPB], where $k^{\prime}=k^{\text {[Catalyst }]^{n}}$ using data from the first 168 hours. Note: This method of calculation provides a significant negative bias in the estimated rate constants:

c. Total soluble boron initial production rates calculated from boron produced in first 168 hours as total soluble boron from ICP-ES analyses of the slurry filtrates. Note rates are based on only two data points (time $=0$ and $168 \mathrm{hr}$ ).

d Soluble organics, soluble metals, solid sludge and solid MST added.

e Soluble organics, soluble metals:

f. Soluble organics, soluble metals and solid sludge added (NO MST).

9 The negative values for soluble boron appearance rates in these control samples result from the observed decrease in soluble TPBover the initial 96 hours of testing.

h Control samples containing No additives. 
Table 14. Reproducibility of Duplicate Tests.a

$\begin{array}{ll}\text { Test } & \text { Temp. Additives } \\ & \left({ }^{\circ} \mathrm{C}\right)\end{array}$
Phenol
(mg/I)

Time, hr

(432) (1008) (1608)
Boron

$(\mathrm{mg} / \mathrm{I})$

Time, hr

(432) (1008) (1608)

\begin{tabular}{lll}
\hline & 40 & $b$ \\
2 & 40 & $b$
\end{tabular}

Average

Standard Deviation

\&Relative Standard Deviation

$3 \quad 55$

55

b

b

Arerage

Standard Deviation

Standard Deviation

\&Relative

$\begin{array}{ll}5 & 70 \\ 6 & 70\end{array}$

b

b

Average

Standard Deviation

qRelative Standard Deviation

$589 \quad 932 \cdot 1346$

413

865

1264

$501 \quad 898 \quad 1305$

124

25

47

5

57

4

142

215

114,187223 .

244

$128 \quad 201 \quad 233$

20

15

$20 \quad 14$

$\begin{array}{rr}20 & 14 \\ 10 & 6\end{array}$

$\begin{array}{lll}526 & 691 & 981\end{array}$

$\begin{array}{lll}858 & 1142 & 1381\end{array}$

\section{0}

220

32.0

286

378

$\begin{array}{lll}692 & 916 & 1181\end{array}$

234

319

282

34

35 .

24

215

303

7. 24

343

49

14

1020. $1217 \quad 1520$

$852 \quad 1202 \quad 1482$

312

245

$402 \quad 468$

322

374

-936 1209

119

13

1501

26

11

279 .

362

420

- 47

57

$\begin{array}{lll}47 & 57 & 66 \\ 17 & 16 & 16\end{array}$

66

a Data shown comes from previous Tables 1 through 6 for final 1600 hours of testing. Standard deviations represent 1 sigma value at $95 \%$ confidence level as calculated by Microsoft ${ }^{\circ}$ EXCEL Version 4.0 spreadsheet function. Relative Standard Deviation defined as ((Standard Deviation/Average) $\times 100$ ).

b Soluble organics, soluble metals, solid sludge and solid Mst added. 
Table 15. Effects of Removing Solid MST Additives or Removing Solid Sludge and Solid MST Additives on NaTPB Decompósition.

\begin{tabular}{|c|c|c|c|c|c|c|}
\hline $\begin{array}{l}\text { Test } \\
*\end{array}$ & $\begin{array}{l}\text { Temp. } \\
:\left({ }^{\circ} \mathrm{C}\right)\end{array}$ & $\begin{array}{l}\text { Missing } \\
\text { Additives }\end{array}$ & & $\begin{array}{l}\text { ICP-ES } \\
\text { ime, h } \\
(1008)\end{array}$ & $(1608)$ & $\begin{array}{c}\text { Boron Ratea } \\
\left.\text { (mole/ }\left(L^{\star} \text { hr }\right)\right) \\
\left(\times 10^{-5}\right)\end{array}$ \\
\hline $\begin{array}{l}3 \\
4\end{array}$ & $\begin{array}{l}55 \\
55\end{array}$ & $\begin{array}{l}\text { (all present) } \\
\text { (all present) }\end{array}$ & $\begin{array}{l}210 \\
220\end{array}$ & $\begin{array}{l}320 \\
286\end{array}$ & $\begin{array}{l}378 \\
307\end{array}$ & $\begin{array}{l}5.5 \\
5.6\end{array}$ \\
\hline $\begin{array}{l}8 \\
7\end{array}$ & $\begin{array}{l}55 \\
55\end{array}$ & $\begin{array}{l}\text { w/O MST } \\
\text { w/O sludge and MST }\end{array}$ & $\begin{array}{l}233 \\
192\end{array}$ & $\begin{array}{l}352 \\
268\end{array}$ & $\begin{array}{l}380 \\
287\end{array}$ & $\begin{array}{l}7.4 \\
4.8\end{array}$ \\
\hline $\begin{array}{l}5 \\
6\end{array}$ & $\begin{array}{l}70 \\
70\end{array}$ & $\begin{array}{l}\text { (all present) } \\
\text { (all present) }\end{array}$ & $\begin{array}{l}312 \\
245\end{array}$ & $\begin{array}{l}402 \\
322\end{array}$ & $\begin{array}{l}468 \\
374\end{array}$ & $\begin{array}{r}10.8 \\
4.8\end{array}$ \\
\hline $\begin{array}{l}10 \\
9\end{array}$ & $\begin{array}{l}70 \\
70\end{array}$ & $\begin{array}{l}\text { w/O MST } \\
\text { w/O sludge and MST }\end{array}$ & $\begin{array}{l}309 \\
176\end{array}$ & $\begin{array}{l}420 \\
286\end{array}$ & $\begin{array}{l}477 \\
317\end{array}$ & $\begin{array}{l}9.4 \\
3.8\end{array}$ \\
\hline
\end{tabular}

a Total soluble boron initial production rates calculated from boron measured in first 168 hours as total soluble boron from ICP-ES analyses of the slurry filtrates. 
Table 16. NaTPB Solids Based on Soluble TPB Analyses and Soluble Boron Analyses.

Test, Temp. Additives $\because \begin{gathered}\text { Final } \\ \text { NaTPBa } \\ \text { Present in } \\ \text { Slurry }\end{gathered}\left({ }^{\circ} \mathrm{C}\right)$
S.

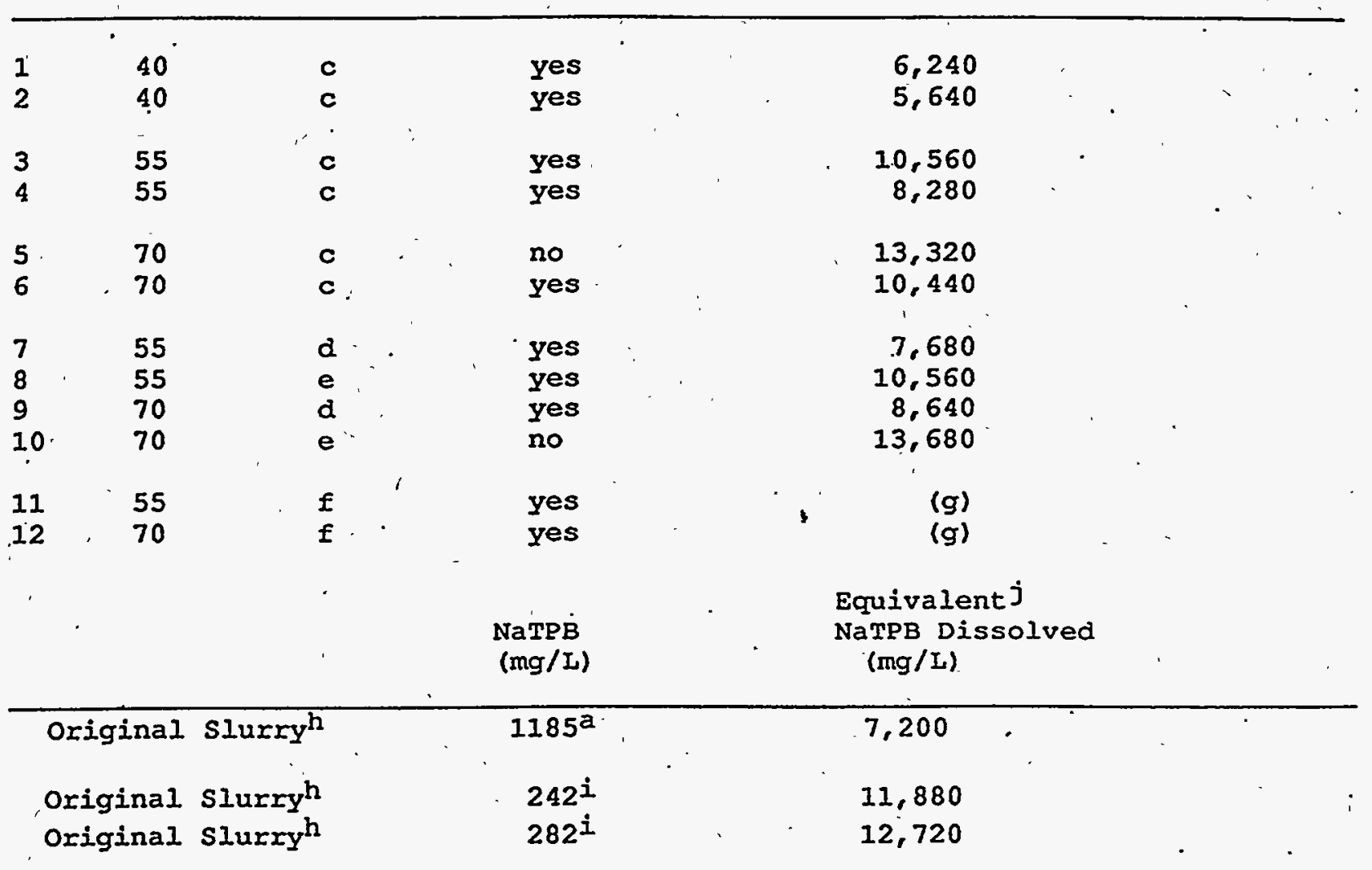

a Determined from HPLC analyses of filtrates obtained from mixing 1 gram slurry amounts with $5 \mathrm{mr}$ of deionized water.

$b$ Based on ICP-ES analyses of soluble boron in filtrates using a nominal slurry density of $1.2 \mathrm{~g} / \mathrm{mL}$. These values represent amount of equivalent solid NaTPB dissolved during testing.

c Soluble organics, soluble metals, solid sludge and solid MST added.

d. Soluble organics, soluble metals.

e Soluble organics, soluble metals and solid sludge added (no MST).

$f$ Control samples containing no additives.

9 Soluble boron analyses in these two samples indicate no significant change (about $704 \pm 170 \mathrm{mg} / \mathrm{L}$ equivalent NaTPB). from $96 \mathrm{hr}$ to the end of testing.

h Obtained from excess slurry used in original tests preparation stored at ambient.temperature for the duration of testing.

$i$ Determined from, HPLC analyses of filtrates obtained from mixing 1 gram slurry amounts with $40 \mathrm{~mL}$ of deionized water after stirring in sealed containers for 12 hours.

$j$ Based on HPLC analyses of filtrates. These values represent amount of equivalent solid NaTPB in the $(\mathrm{K} ; \mathrm{Na}) \mathrm{TPB}$ slurries. 
Table 17. Analyses for Soluble Potassium Ion from (K, Na)TPB slurries Tested at 40 to $70^{\circ} \mathrm{C}$.

\begin{tabular}{|c|c|c|c|c|c|c|}
\hline Test & $\begin{array}{c}\text { Temp. } \\
\left({ }^{\circ} \mathrm{C}\right) \\
.\end{array}$ & Additives & $\begin{array}{l}\text { Final } \\
\text { Potassium } \\
\text { in Filtrates } \\
\text { (mg/L) }\end{array}$ & $\begin{array}{l}\text { Equivialent } \\
\text { KTPB } \\
\text { Dissolved } \\
\text { (mg/L) }\end{array}$ & $\begin{array}{l}\text { Equivalent } \\
\text { NaTPB } \\
\text { Dissolved } \\
\text { (mg/I) }\end{array}$ & \\
\hline $\begin{array}{l}1 \\
2\end{array}$ & $\begin{array}{l}40 \\
40\end{array}$ & $\begin{array}{c}d \\
d\end{array}$ & $\begin{array}{l}2.7 \\
2.2\end{array}$ & $\begin{array}{l}36 \\
24\end{array}$ & $\begin{array}{l}6,240 \\
5,640\end{array}$ & \\
\hline $\begin{array}{l}3 \\
4\end{array}$ & $\begin{array}{r}.55 \\
55\end{array}$ & $\begin{array}{l}d \\
d\end{array}$ & $\begin{array}{l}144.0 \\
6.6\end{array}$ & $\begin{array}{r}1,320 \\
60\end{array}$ & $\begin{array}{r}10,560 \\
8,280\end{array}$ & \\
\hline $\begin{array}{l}5 \\
6\end{array}$ & $\begin{array}{l}70 \\
70\end{array}$ & $\begin{array}{l}d \\
d\end{array}$ & $\begin{array}{l}420.0 \\
209.0\end{array}$ & $\begin{array}{l}3,984 \\
1,920\end{array}$ & $\begin{array}{l}13,320 \\
10,440\end{array}$ & \\
\hline $\begin{array}{l}7 \\
8 \\
9 \\
10\end{array}$ & $\begin{array}{l}55 \\
55 \\
70 \\
70\end{array}$ & $\begin{array}{l}e \\
f \\
e \\
f\end{array}$ & $\begin{array}{r}8.9 \\
209.0 \\
48.0 \\
506.0\end{array}$ & $\begin{array}{r}84 \\
1,920 \\
444 \\
4,656\end{array}$ & $\begin{array}{r}7,680 \\
10,560 \\
8,640 \\
13,680\end{array}$ & \\
\hline $\begin{array}{l}11 \\
12\end{array}$ & $\begin{array}{l}55 \\
70\end{array}$ & $\begin{array}{l}g \\
g\end{array}$ & $\begin{array}{l}3.5 \\
2.7\end{array}$ & $\begin{array}{l}36 \\
24\end{array}$ & $\begin{array}{l}\text { (h) } \\
\text { (h) }\end{array}$ & 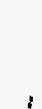 \\
\hline \multicolumn{3}{|c|}{ Original slurryi } & 0.2 & $<2$ & NAj & \\
\hline
\end{tabular}

a Determined from Atomic Absorption analyses of slurxy filtrates.

b Based on Atomic Absorption analyses for. soluble potassium ion in filtrates using a nominal slurry density of $1.2 \mathrm{~g} / \mathrm{mL}$. These values represent amount of equivalent solid KTPB that was dissolved during testing.

c Data repeated from Table 16 based on ICP-ES analyses of soluble boron in filtrates using a nominal slurry density of $1.2 \mathrm{~g} / \mathrm{mL}$. These values represent amount of equivalent solid NaTPB dissolved during testing.

d Soluble organics, soluble metals, solid sludge and solid MST added:

e Soluble organics, soluble metals.

f Soluble organics, soluble metals and solid sludge added (no MST).

$g$ Control samples containing no additives.

h Soluble boron analyses in these two samples indicate no significant change (about $704 \pm 170 \mathrm{mg} / \mathrm{L}$ equivalent NaTPB) from $96 \mathrm{hr}$ to the end of testing.

$i$ Obtained from excess slurry used in original tests preparation stored at ambient temperature for the duration of testing.

$j$ Soluble boron was not analyzed from the excess slurry used in the original tests. 
Table 18. Comparison of Previous Tank 48H Data with Present $(\mathrm{K}, \mathrm{Na}$ ) TPB Slurry Decomposition Data

Tank' $48 \mathrm{H}^{\mathrm{a}}$

$\left(25-52{ }^{\circ} \mathrm{C}\right) \mathrm{b}$ :

Present. Tests $c, d$

$\left(40^{\circ} \mathrm{C}\right)$

$\left(55{ }^{\circ} \mathrm{C}\right)$

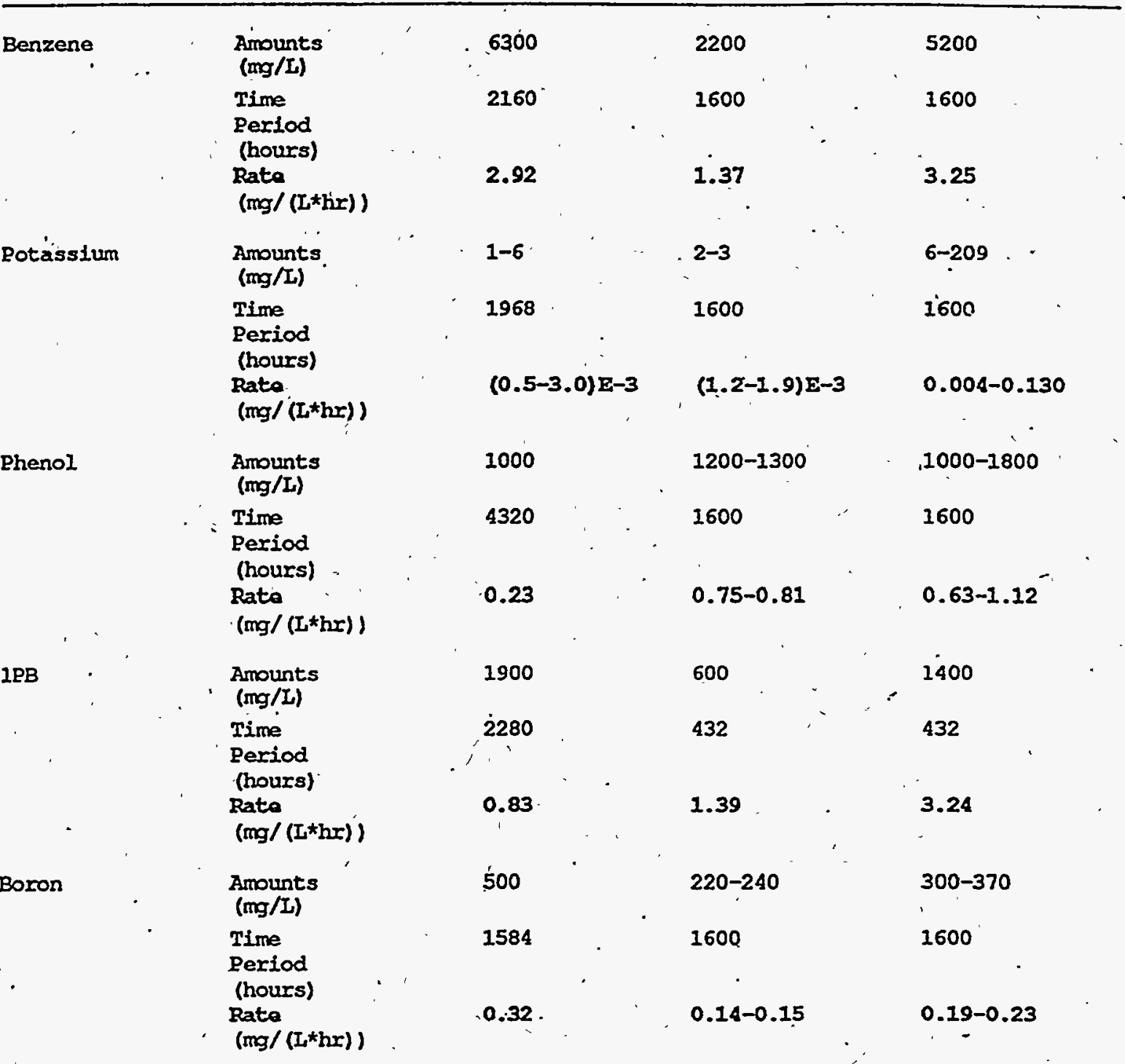

a Data for Tank $48 \mathrm{H}$ obtained from Figure 3 (temperature range) and

Table 2 (species concentrations) in Ref. 1. The magnitudes of all species represent maximium amounts produced over the approximate time periods indicated.

b Tank $48 \mathrm{H}$ recorded temperatures ranged from 25 to $52{ }^{\circ} \mathrm{C}$ from August 31, 1995 to April 27, 1996. Note however, Erom Ref. 1 that Tank 48H temperatures ranged from 33 to $52{ }^{\circ} \mathrm{C}$ from Auqust.31; 1995 to mid-November of 1995.

c. Data for the $40^{\circ} \mathrm{C}$ studies obtained from Tables 1 and 2 for tests containing full set of additives. The magnitudes of all species represent maximum amounts produced over the approximate time periods indicated.

d Data for the $55^{\circ} \mathrm{C}$ studies obtained from Tables 3 and 4 for tests containing full set of additives. The magnitudes of all species represent maximum amounts produced over the approximate time periods indicated. 
Figure 1. Benzene Production for Tests 1 and 2 at $40^{\circ} \mathrm{C}$ with All Additives.
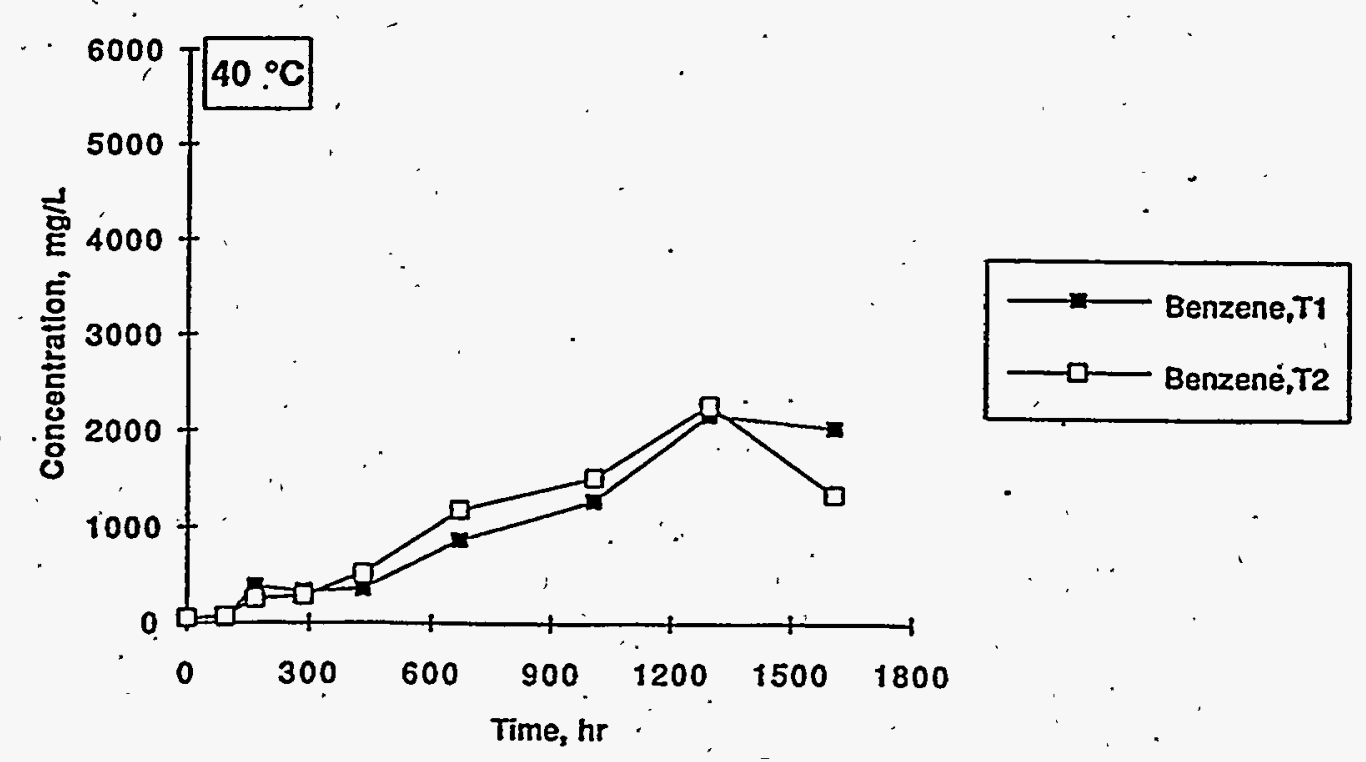

Figure 2. Benzene production for Tests 3 and 4 at $55^{\circ} \mathrm{C}$ with $\mathrm{All}$ Additives:
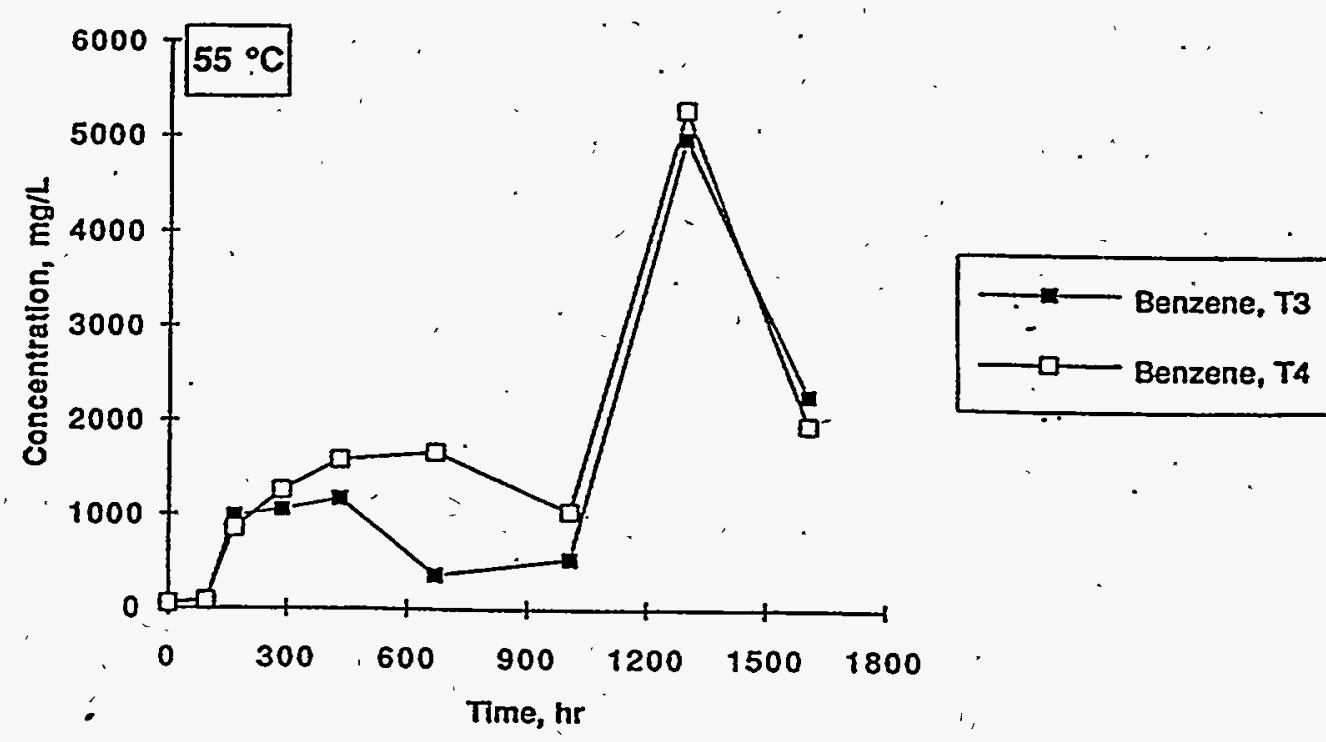
Figure 3. Benzene Production for Tests 5 and 6 at $70{ }^{\circ} \mathrm{C}$ with $\mathrm{All}$ Additives.

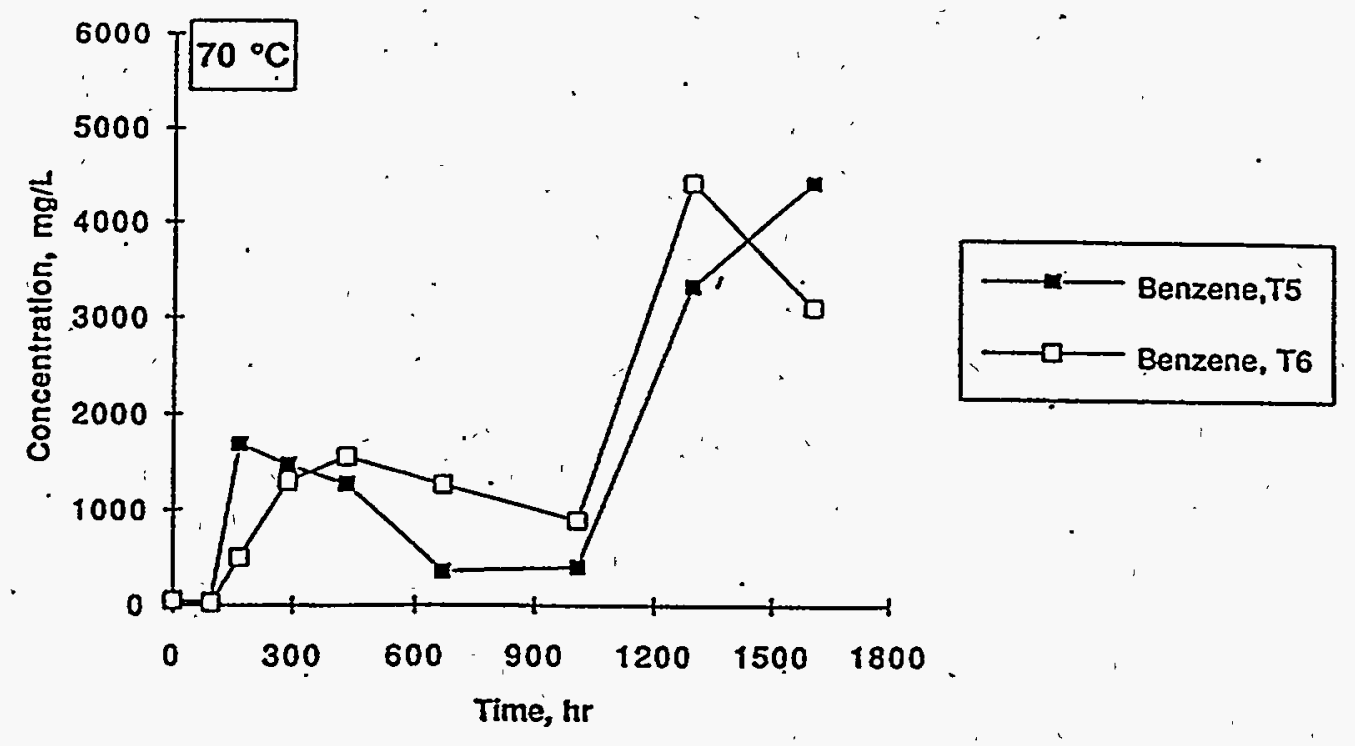

Figure 4. Benzene Production for Tests at 55 and $70^{\circ} \mathrm{C}$ with Either Soluble Additives Only (i.e., Test 7 and Test 9) or Soluble Additives plus Slúdge Solids (i.e., Test 8 and Test 10).

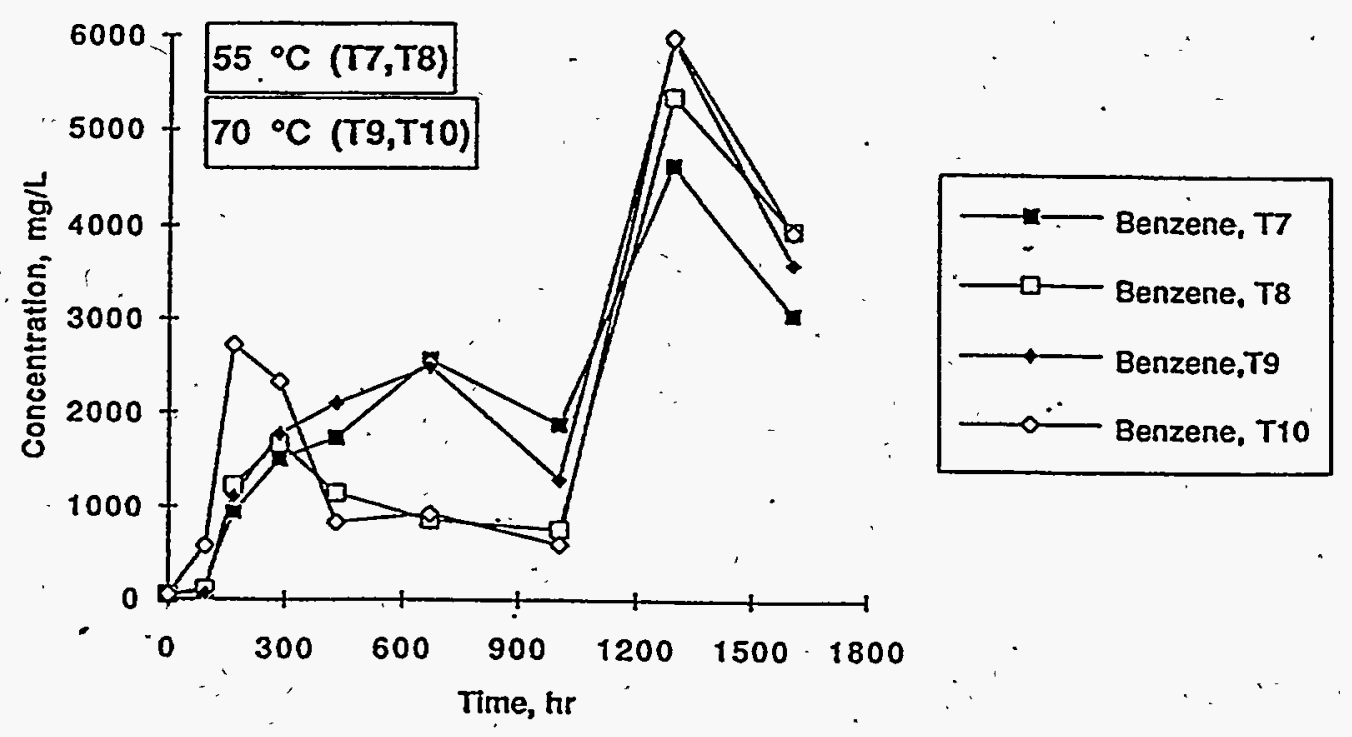


Figure 5. Benzene Production for Control Sample Tests 11 and 12 at 55 and $70^{\circ} \mathrm{C}$, respectively, with No Additives Present.
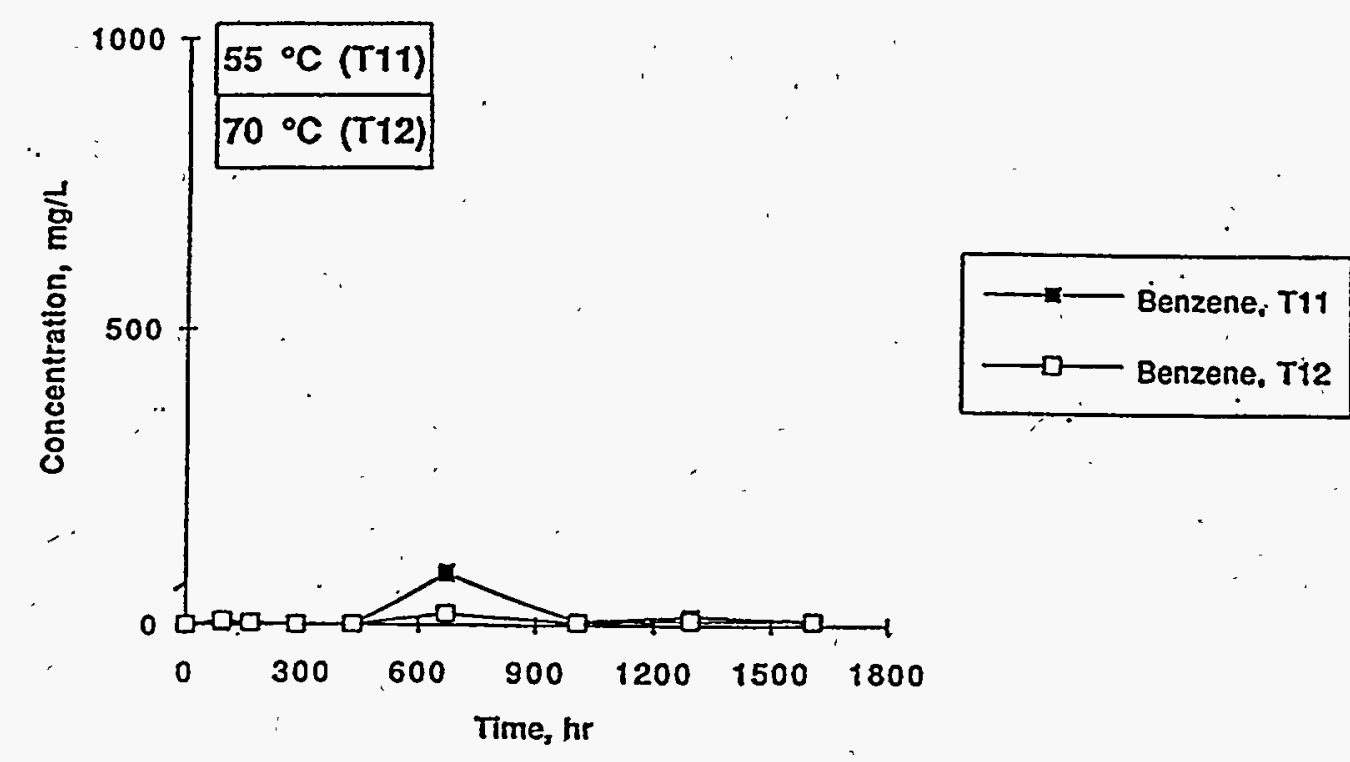
Figure 6. Average Tetraphenylborate, Intermediates and Product Concentrations versus Time for Duplicate Tests 1 and 2 at $40{ }^{\circ} \mathrm{C}$ with $\mathrm{AlI}$ Additives.
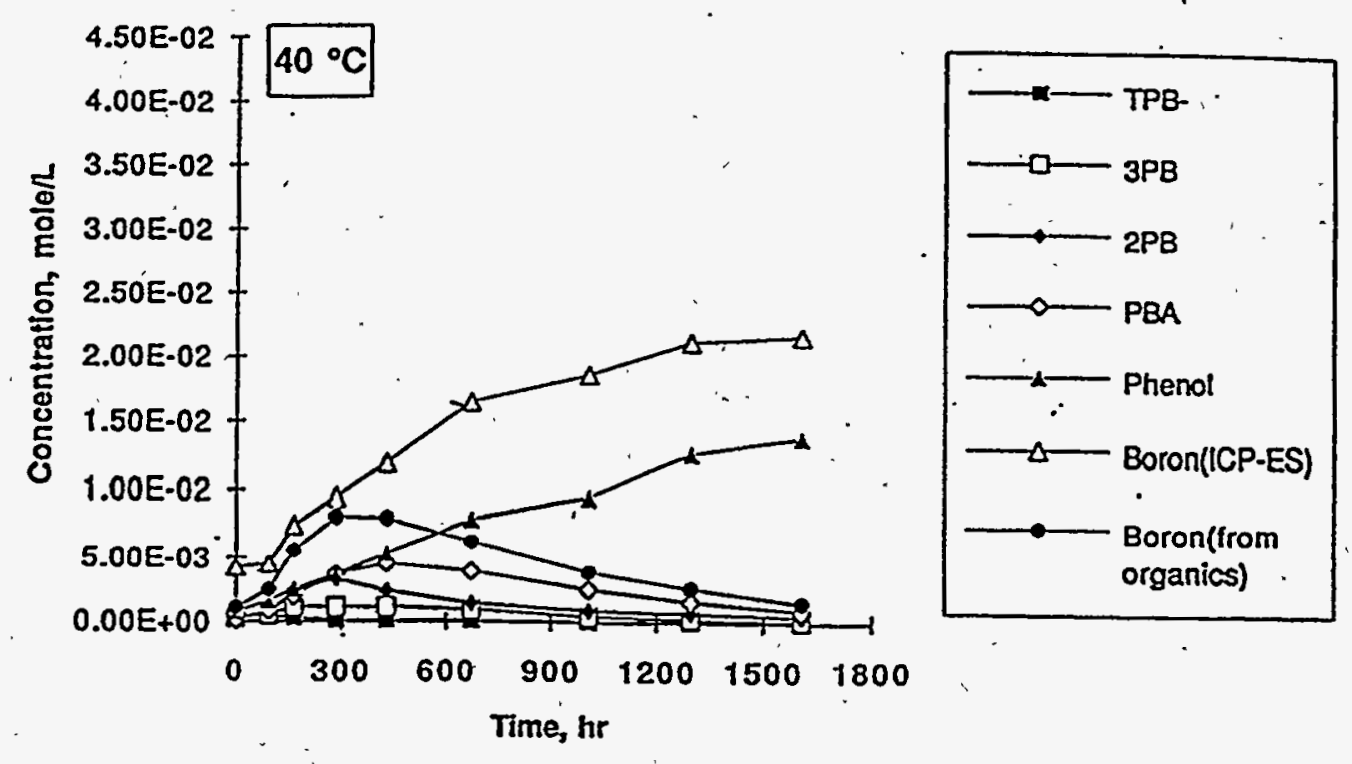

Figure 7. Average Tetraphenylborate, Intermediates and Product Concentrations versus Time for Duplicate Tests 3 and 4 at $55^{\circ} \mathrm{C}$, with AII Additives.
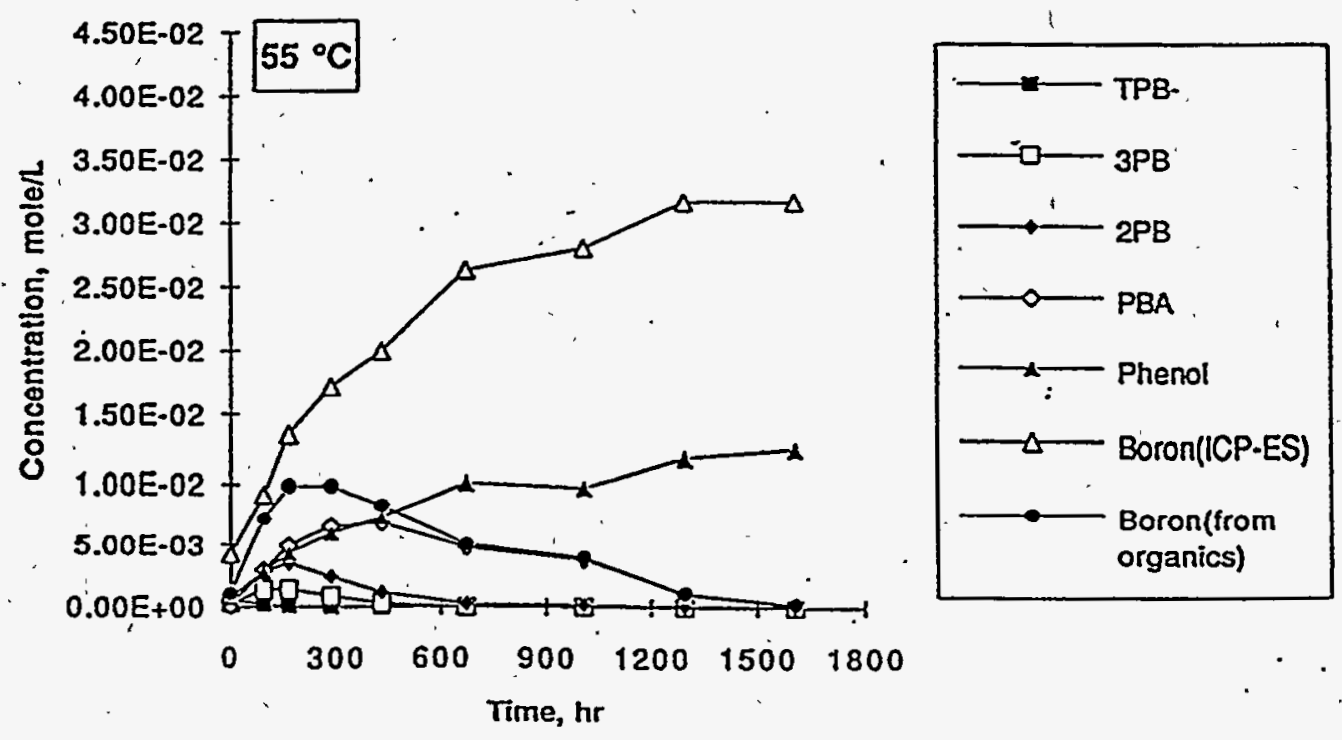
Figure 8: Average Tetraphenylborate, Intermediates and Product Concentrations versus Time for Duplicate Tests 5 and 6 at $70^{\circ} \mathrm{C}$ with $\mathrm{AII}$ Additives.
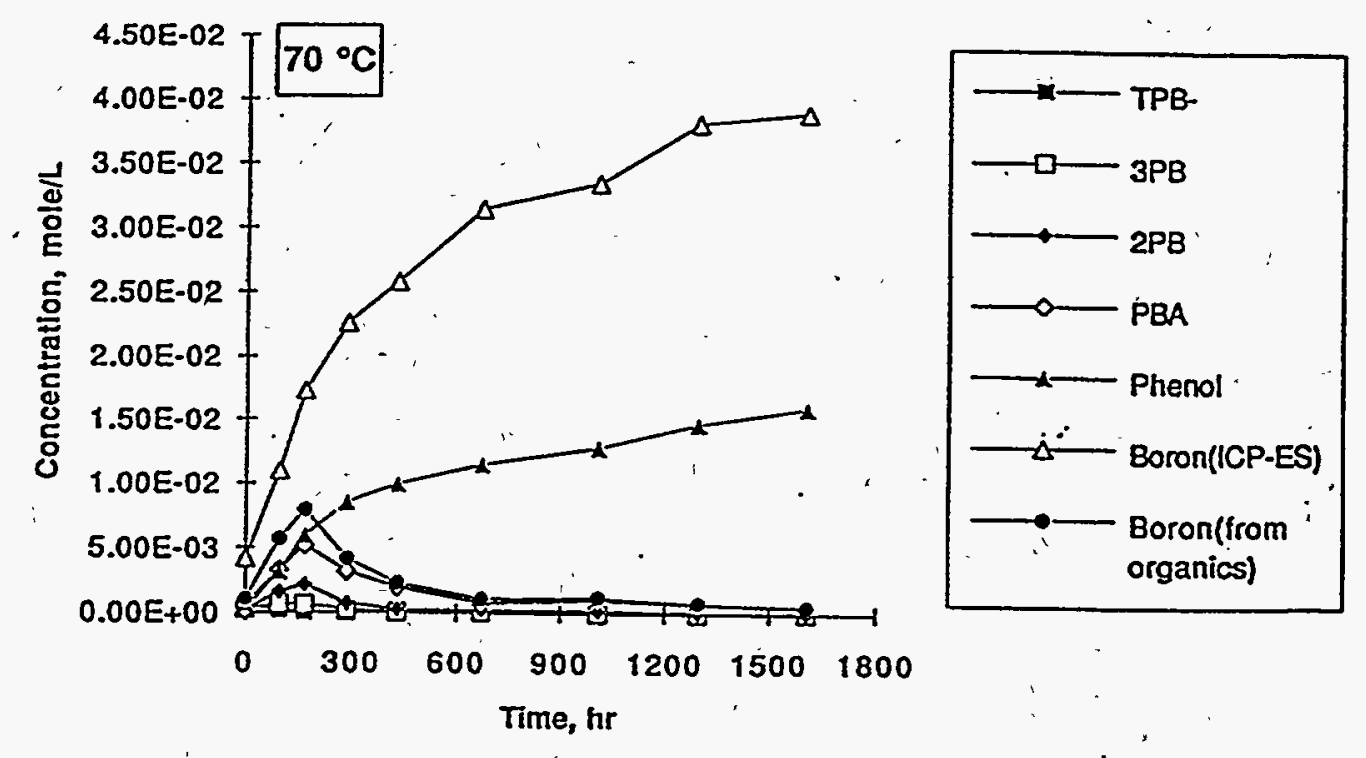
Figure 9. Tetraphenylborate, Intermediates and Product. Concentrations versus Time for Test 7 at $55^{\circ} \mathrm{C}$ with Soluble Additives Only.
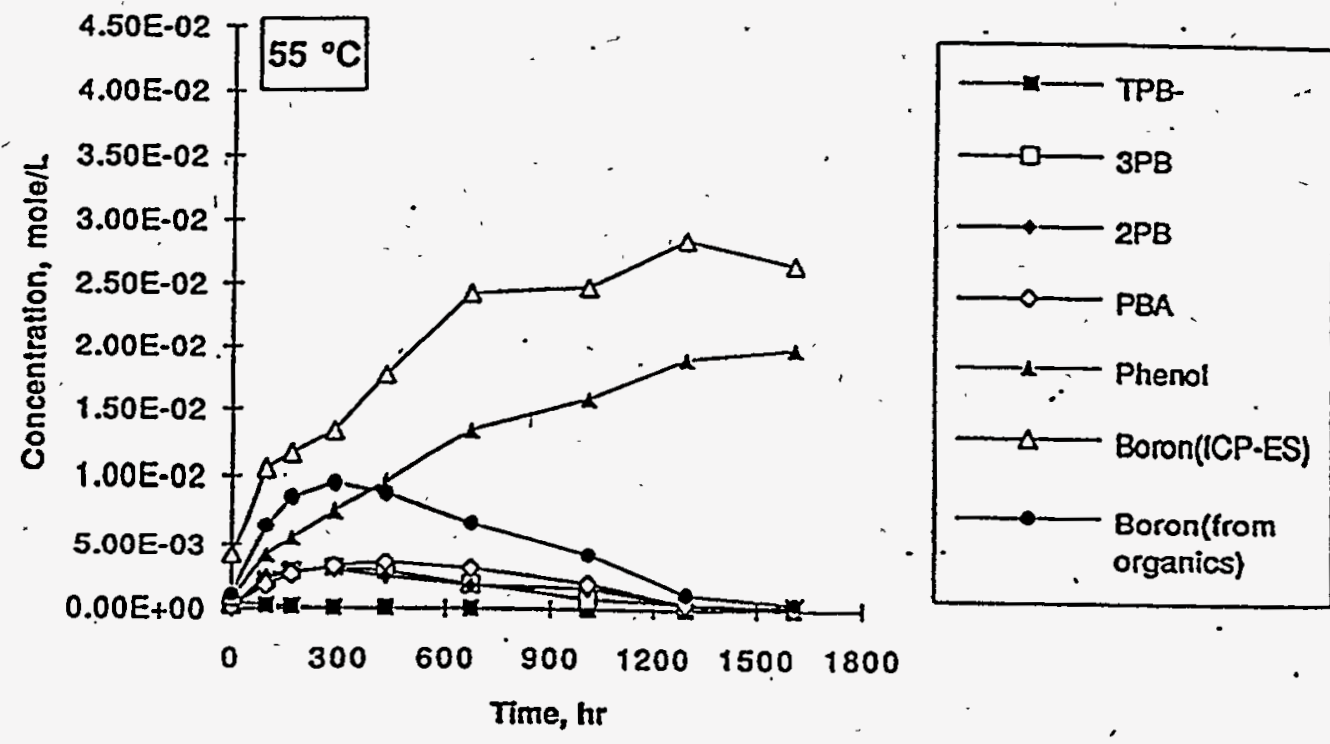

Figure 10 Tetrapheny Iborate, Intermediates and Product Concentrations versus Time for Test 8 at $55^{\circ} \mathrm{C}$ with Soluble, Additives PIus Sludge Solids.
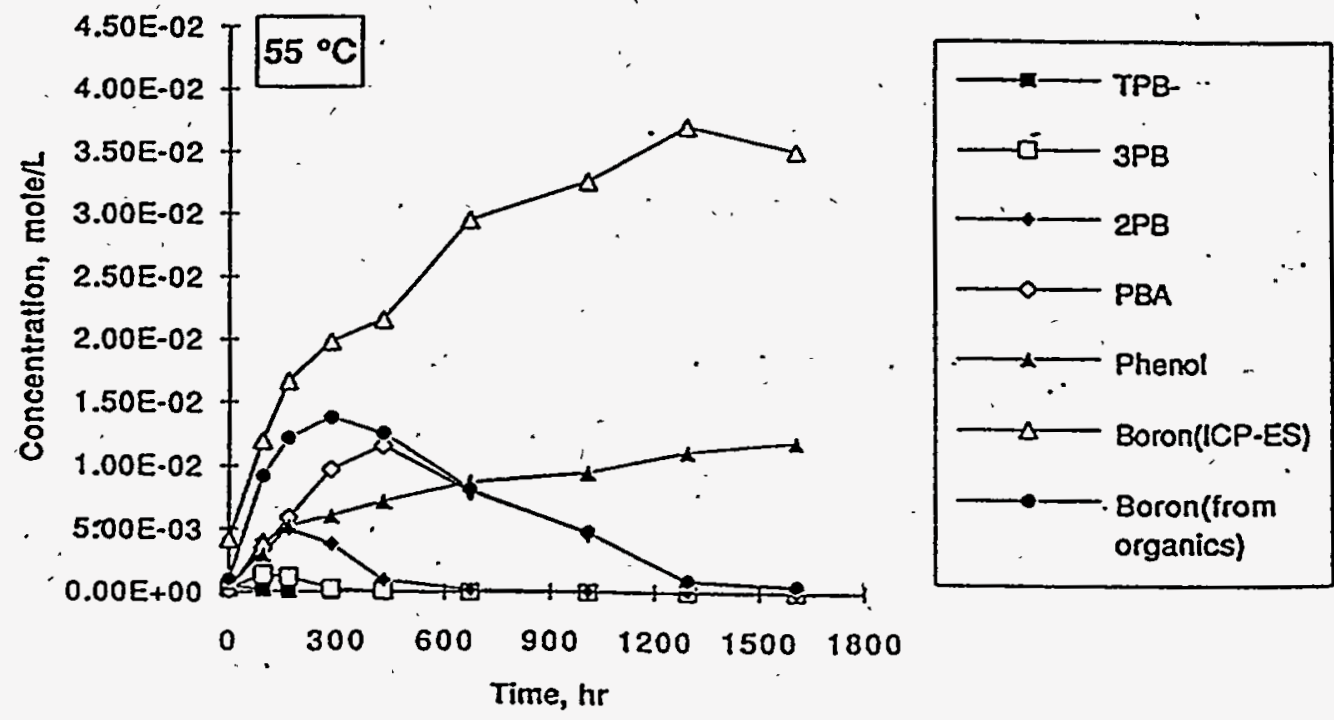
Figure 11. Tetraphenylborate, Intermediates and Product Concentrations versus Time for Test 9 at $70^{\circ} \mathrm{C}$ with Soluble Additives Onlỳ.
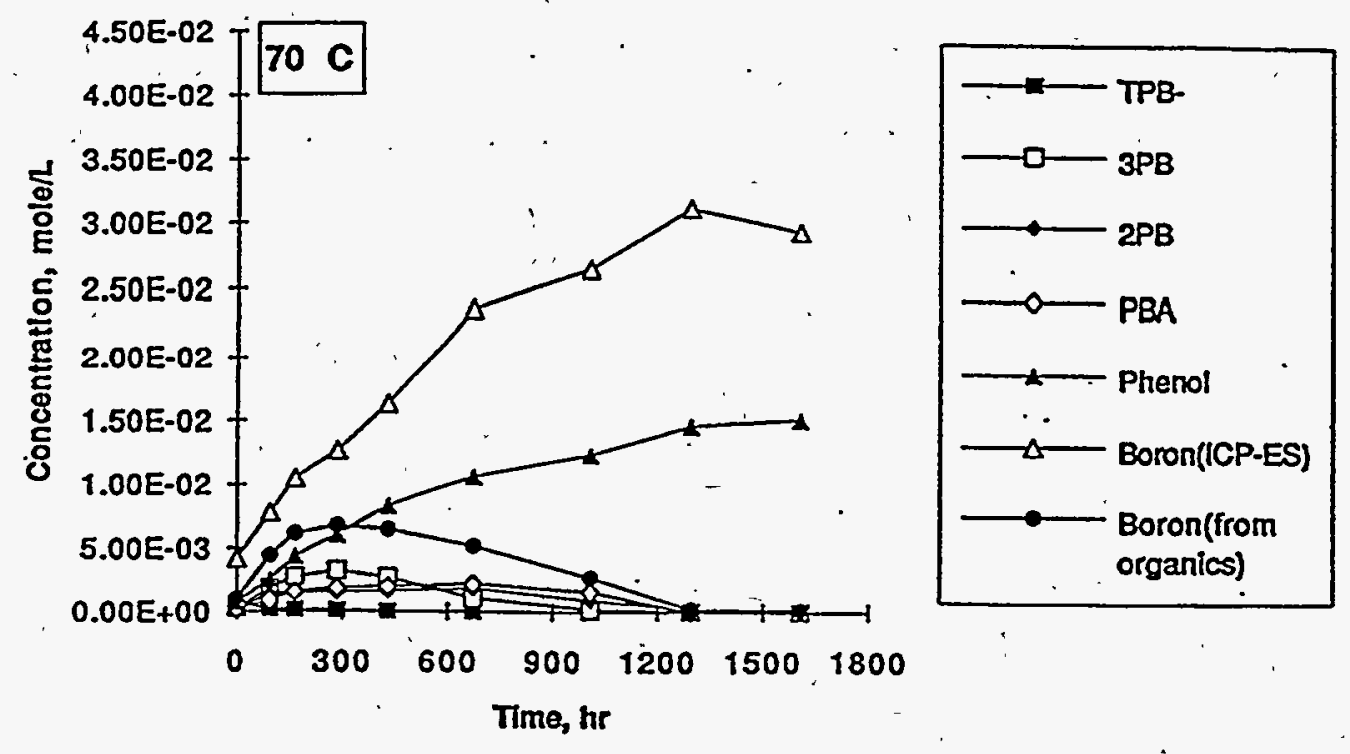

Figure 12. Tetraphenylborate, Intermediates and Product Concentrations versus Time' for Test 10 at ' $70^{\circ} \mathrm{C}$ with Soluble idditives Plus Sludge Solids.
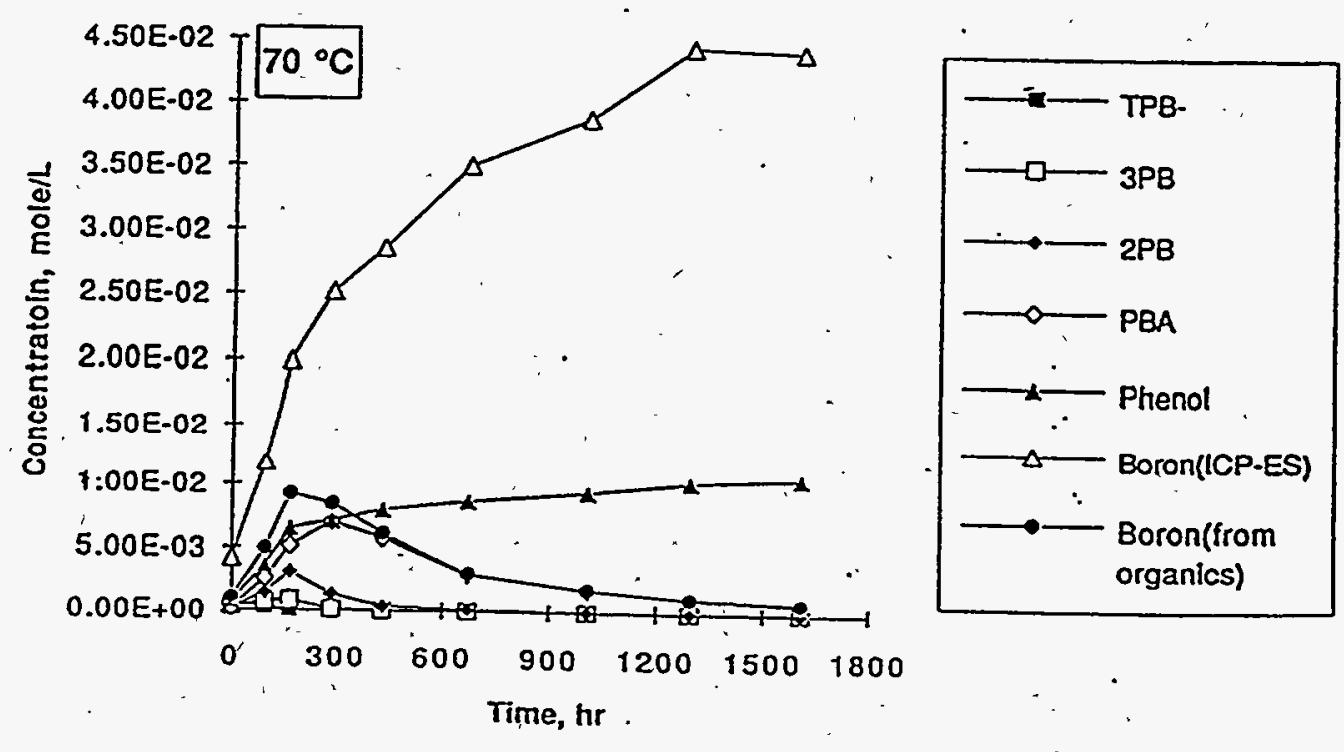
Eigure 13. Tetraphenylborate, Intermediates and Product'

Concentrations versus Time for Control Sample Test 11 at $55^{\circ} \mathrm{C}$ with No Additives.
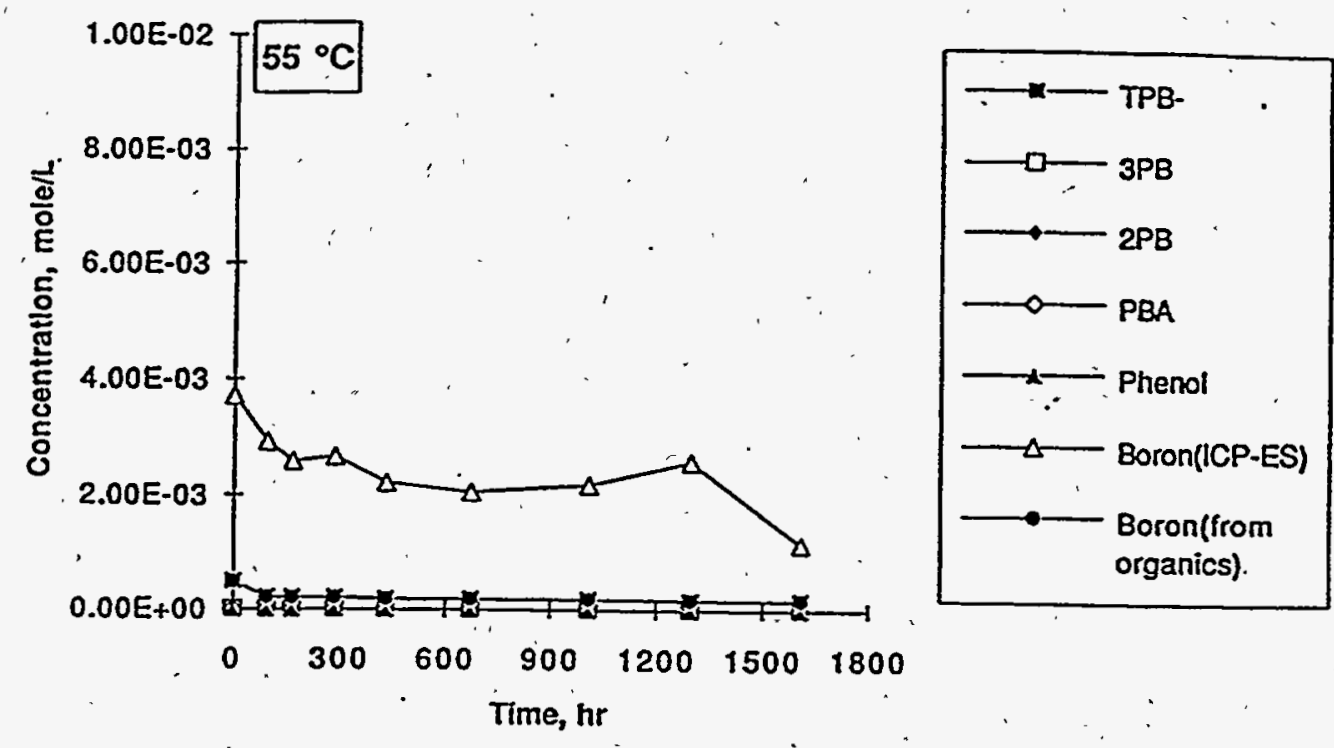

Figure 14. Tetraphenylborate, Intermediates and Product Concentrations versus Time for Control Sample Test 12 at $70^{\circ} \mathrm{C}$ with No Additives.

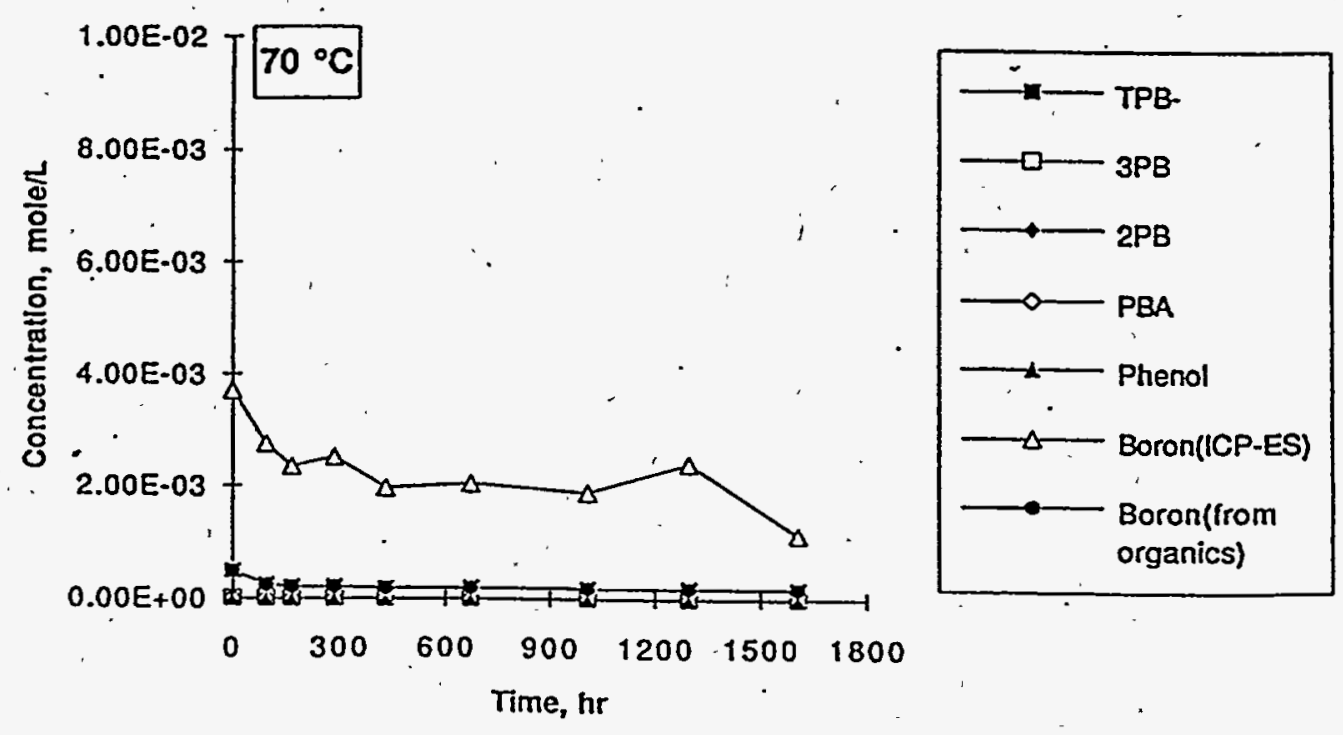


Figure 15. Arrhenius Plot of In (initial soluble boron rate) 'versus Inverse Temperature.

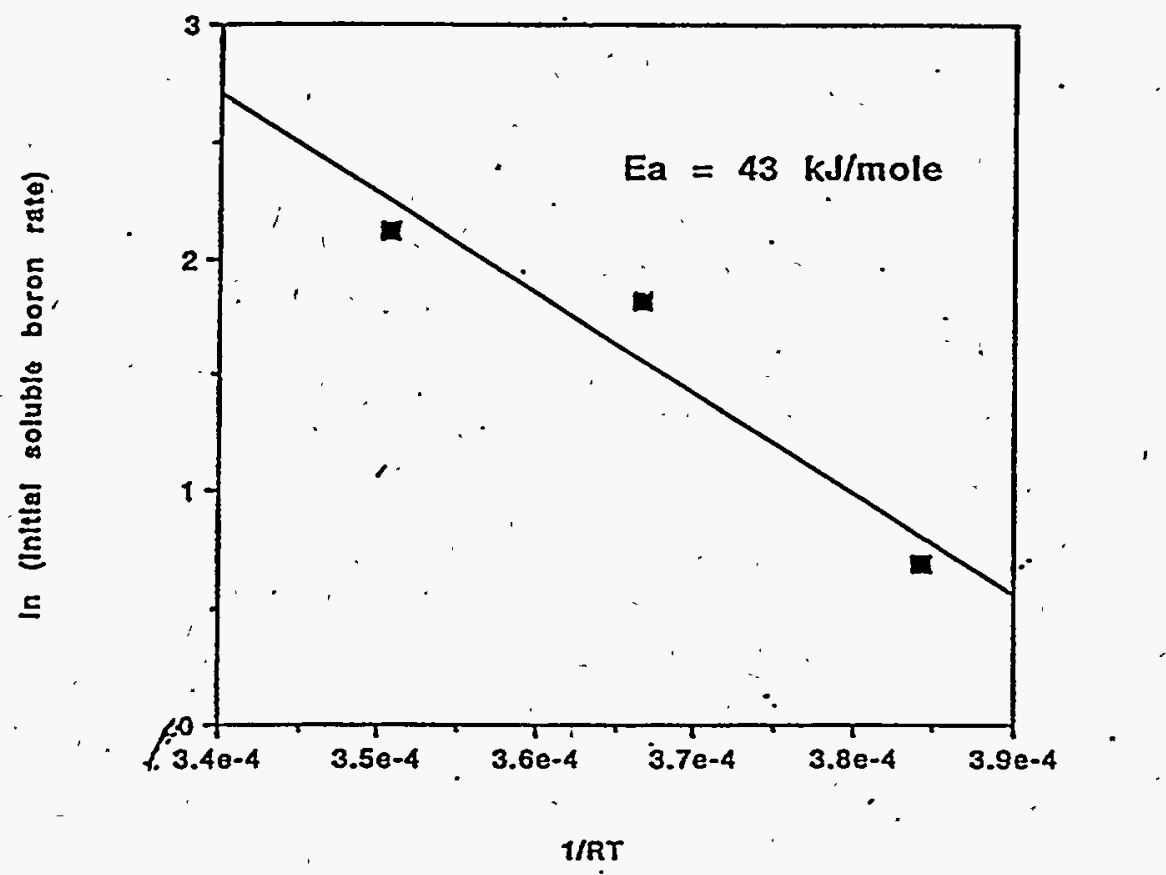


Figure 16. Soluble Boron (ICP-ES) and Phenyl Borate (HPIC) Concentrations versus Time for Test 8 at $55{ }^{\circ} \mathrm{C}$ with Soluble Additives PIus Sludge Solids (w/out MST) Compared to Averages from Duplicate Tests 3 and 4 at $55^{\circ} \mathrm{C}$ with All Additives.

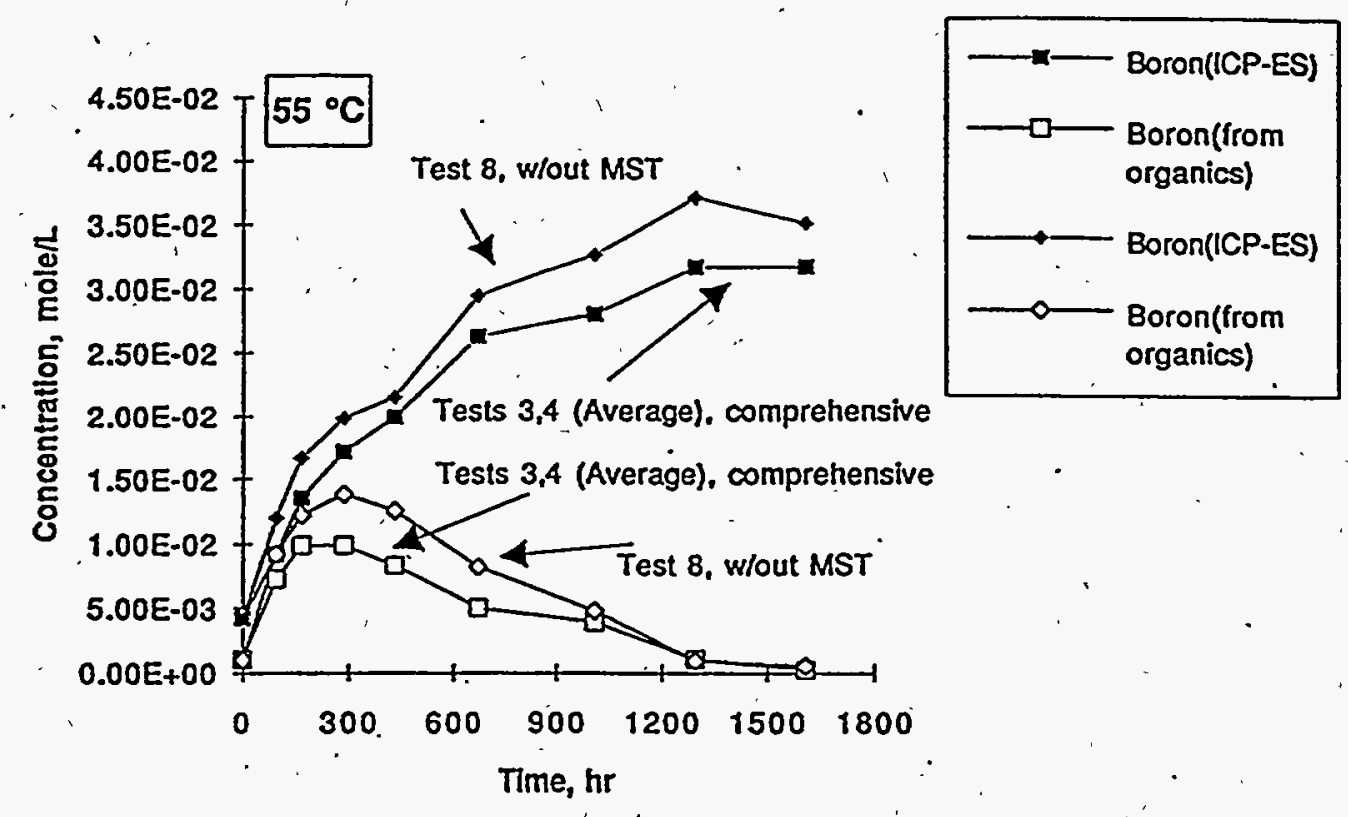

Figure 17. Soluble Boron (ICP-ES) and Phenyl Borate (HPLC) Concentrations versus Time for Test 10 at $70{ }^{\circ} \mathrm{C}$ with Soluble Additives Plus Sludge Solids (w/out MST) Compared to Averages from Duplicate Tests 5 and 6 at $70{ }^{\circ} \mathrm{C}$ with All Additives.
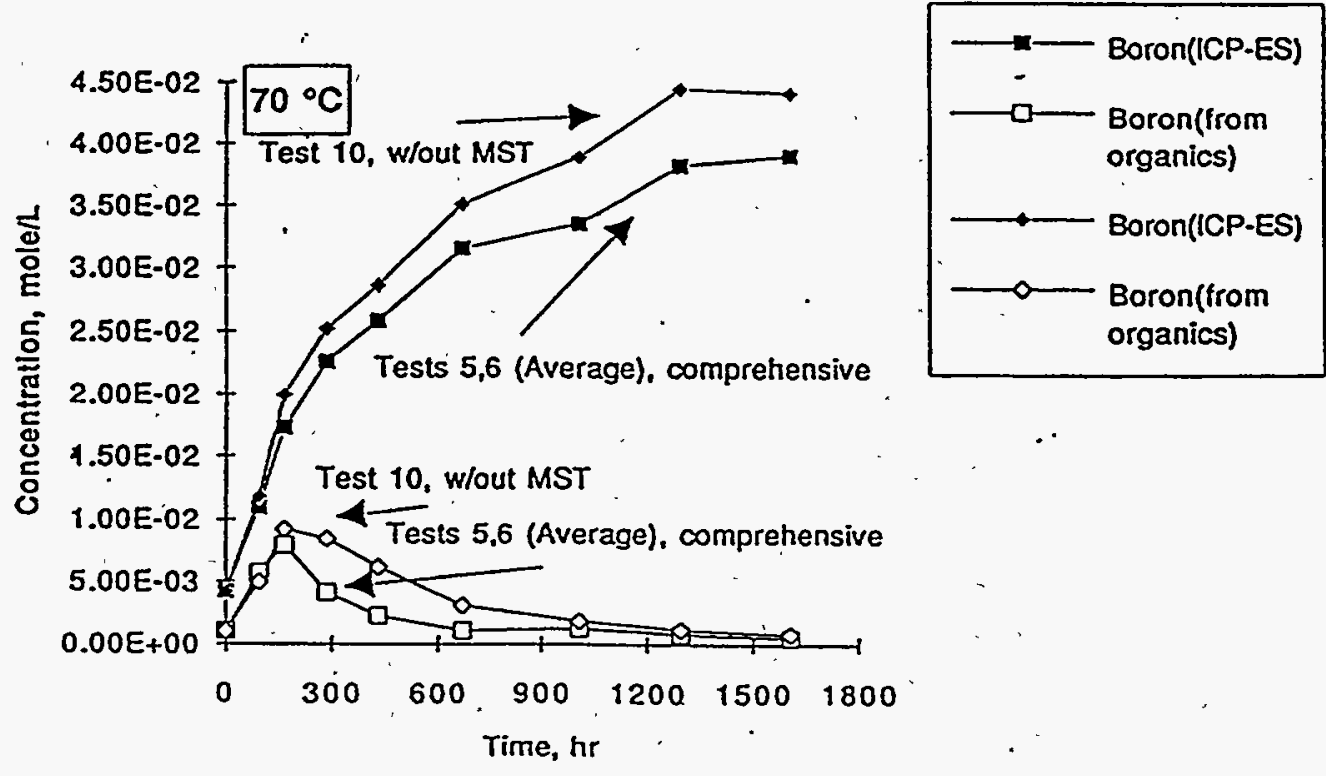
Eigure 18. Soluble Boron (ICP-ES) and Phenyl Borate (HPIC) Concentrations versus Time for Test 7 at $55^{\circ} \mathrm{C}$ with Soluble Additives (w/out sludge and MST) Compared to Averages from Duplicate Tests 3 and 4 at $55^{\circ} \mathrm{C}$ with All Additives.
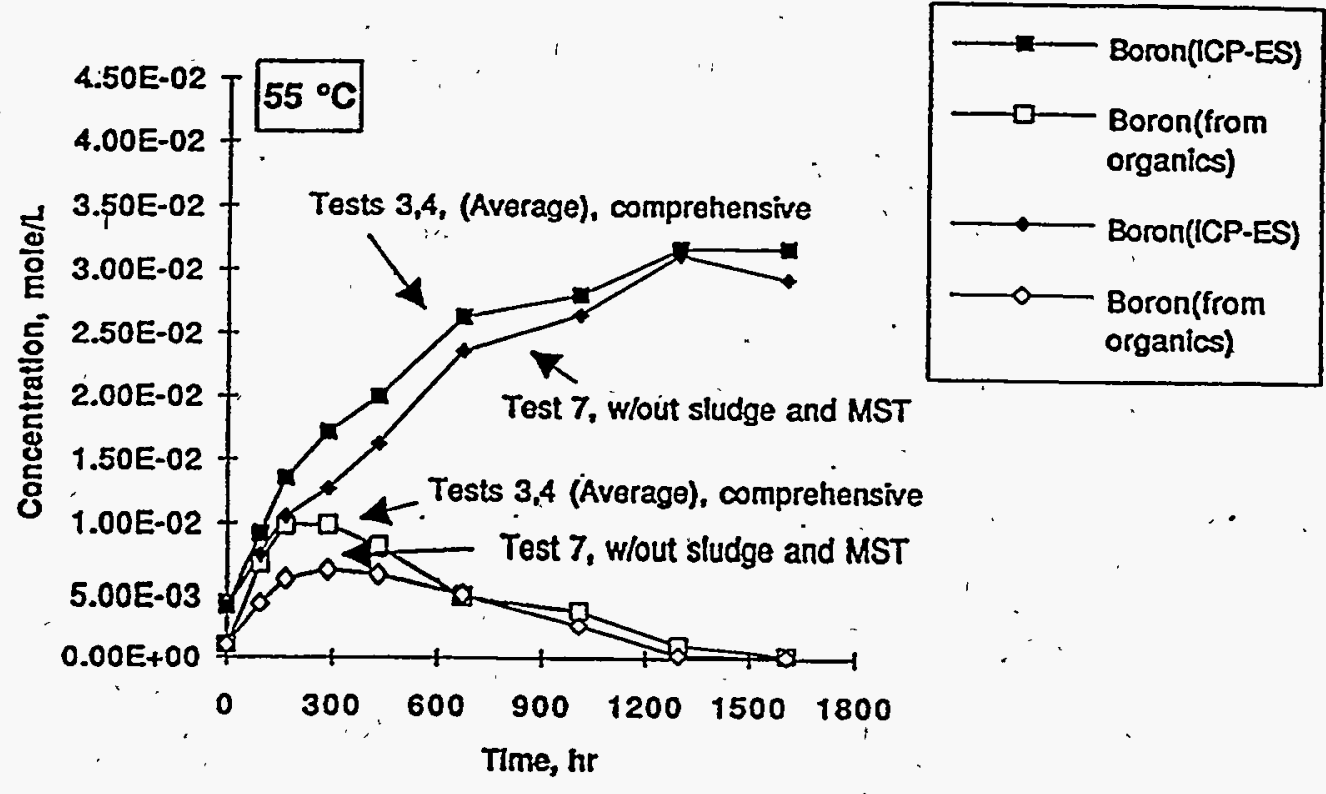

Figure 19. Soluble Boron (ICP-ES) and Phenyl Borate (HPIC) Concentrations versus Time for Test 9 at $70{ }^{\circ} \mathrm{C}$ with Soluble Additives (w/out sludge and MST) Compared to Averages from Duplicate Tests 5 and 6 at $70{ }^{\circ} \mathrm{C}$ with $\mathrm{AII}$ Additives.
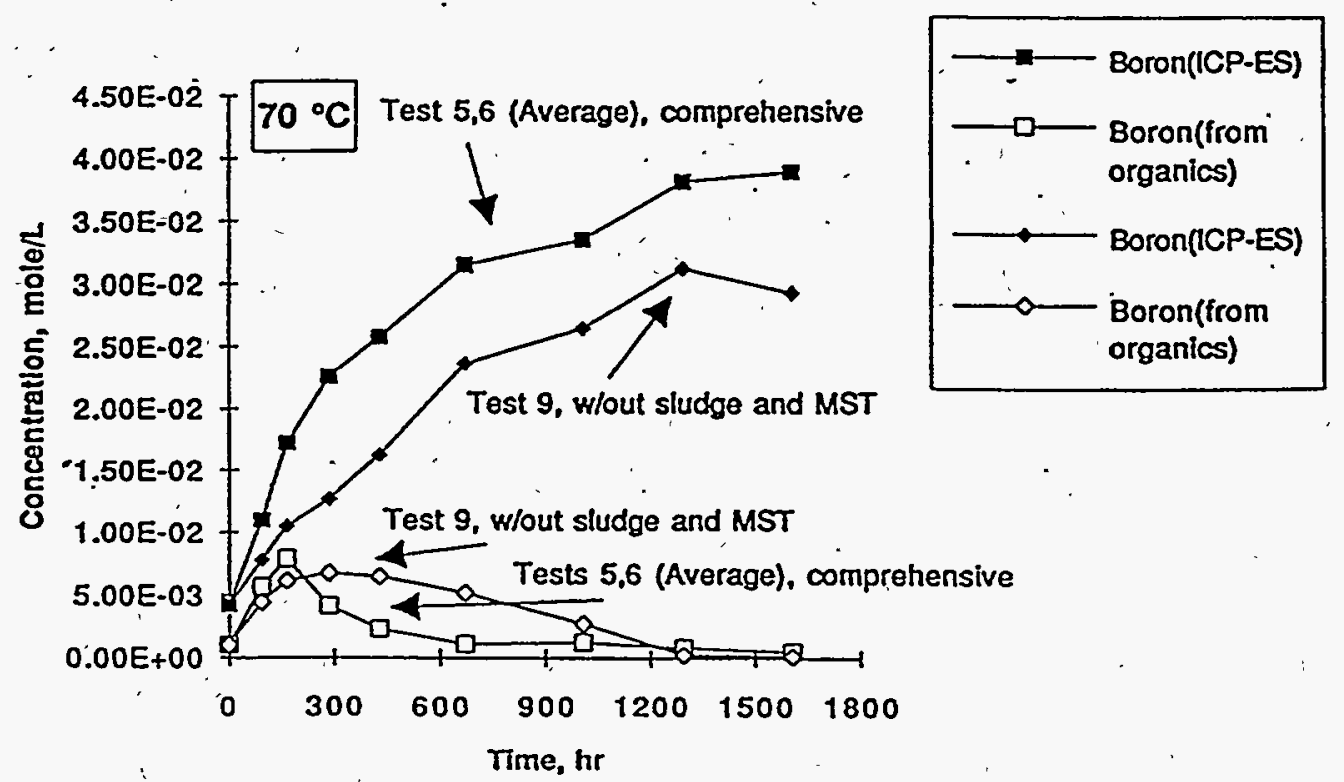


\section{QUAIITY ASSURANCE}

The experimental methods and results were recorded in laboratory notebook WSRC-NB-95-308. The task plan and quality assurance plans are:

C. I. Crawford, "Tásk Technical Plan for Decomposition Studies of Tetraphenẏlborate Slúrries (U) ", WSRC-RP-96-549, Rev. 0, October 23, 1996:

C. L. Crawford, "Task Quality Assurance Plan - Decomposition Studies of Tetraphenylborate Slurries (U) ", WSRC-RP-96-550, Rev. 0, October 23, 1996."

\section{'REFERENCES}

1. D. D. Walker, M. J. Barnes, C. I. Crawford, R. F. Swingle, R. A. Peterson, M. S. Hay and S. D. Fink, "Decomposition of Tetraphenylborate in Tank 48-H (U) ", FSRC-TR-96-0113, May 10, 1996.

2. "Department of Energy Implementation Plan for Defense Nuclear Facilities Safety Board Recommendation 96-1 to the Secretary of Energy, In-Tank Precipitation Facility at the Savannah River Site", A. Lee Watkins, DNESB 96-1 Implementation Plan, Rev. 0, October $21,1996$.

3. M. J. Barnes, "Decomposition of Sodium Tetraphenylborate (U) ", WSRC-RP-90-465, MaY 10, 1990.

4. D. D. Walker and C. A. Nash, "Results from-Tank $48 \mathrm{H}$ Slurry Decontamination and Decomposition Experiments in Support of ITP Process Verification Testing (U) ", WSRC-TR-96-0190, September 6, 1996.

5. M. J. Barnes, C. L. Crawford; C. A. Nash and T. B. Edwards; "Task Technical Plan for Sodium Tetraphenylborate Decomposition Catalyst Identification Studies (U)", WSRC-RP-96-600, ReV. 0, December 10, 1996.

6. J. E. Marra and J. T. Carter, "Soluble TPB Decomposition and Catalysis", HLE-TTR-97008, November 14, 1996.

7. J. E. Marra and J. T. Carter, "Effect of Sludge Solids and ST. on TPB Decomposition", HLE-TTR-97012, November 14, 1996.

8. C. I. Crawford and R. A. Peterson, "Decomposition Studies of Triphenylboron, Diphenylborinic Acid and Phenylboric Acid in Aqueous Alkaline Solutions Containing Copper (U) ", WSRC-TR-97-0045, Rev. 0, February 11, 1997.

9. P. W. Atkins, Physical Chemistry, Chapter 27 - "The Rates of Chemical Reaction's", pp 920-968, W. H. Freeman and Co., San Erancisco, CA, 1982.

10. M. J. Barnes and T. B. Edwards, "Copper Catalyzed Sodium Tetraphenylborate Decomposition Kinetic Studies (U) ", WSRC-TR-960351, Rev. 0, November 7, 1996. 
11. D. J. McCabe, "Cesium, Potassium, and Sodium Tetraphenylborate Solubility in Salt Solution (U) ", WSRC-TR-96-0384, ReV. 0, December $16,1996$.

12. D. D. Walker, M. I. Hyder, M. J. Barnes, C. L. Crawford and R. A. Peterson, "Intermediate Decomposition Rates", SRP-LWP-97-0021, , Rev. 0, February, 26, 1997.

13. M. L. Hyder, "The Role of Oxygen in the Copper-Catalyzed. Decomposition of Phenyl Borates in Aqueous. Alkaline Solutions (U) ", WSRC-TR-97-0069, Rev. 0, March 17, 1996.

14. a) Analytical Development Section, QA Implementation Manual, $1031-3$.

b) Analytical Development Section, Analytical operating Procedures Manual, II6.1.

15. C. I. Crawford, "Preliminary High-Pressure Liquid Chromatography (HPLC) Analyses of Composite Mixtures of Tetraphenylborate, Triphenylboron, Diphenylboronic Acid, Phenylboric Acid and Phenol in Aqueous Alkaline Salt Solutions $(U)$ ", WSRC-TR-96-0364, Rer. 0 , December 18, 1996. 
APPENDIX A

TEST' DESIGN AND EXPERIMENTAL METHODS AND ANATYSES

A total of 12 slurry samples were tested. The test matrix, sample preparations and analytical methods are described below.

The test matrix for six slurry plus additive samples (V1-6) was identical except for the different temperatures of 40,55 and $70{ }^{\circ} \mathrm{C}$ (see V1-6 of Table Al). Each (K, Na) TPB slurry consisted of the simulated slurry in concentrated salt solution containing the soluble métal, soluble organics, and solid sludge and MST additives shown in Table A2. The non-radioactive recipe given in Table A2 best approximates the Tank $48 \mathrm{H}$ radioactive slurry (See specifically Tables 2, 8, 9 and 12 of Ref. 1). As noted in Table A2, the NaTPB fraction of the (K, Na) TPB solids is purposely made higher (targeted to contain 1.5 wt 8 NaTPB solids or about $18,0,00 \mathrm{mg} / \mathrm{I}$ NaTPB solids) relative' to the measured 0.6 wt $\frac{\text { q }}{\mathrm{t}} \mathrm{TPB}$ value in Tank $48 \mathrm{H}$ slurry. This, was done to assure an adequate amount of excess NaTRB so the extent of reaction can be monitored in the planned decomposition tests. These samples, vi-6, were tested in duplicate at each temperature. Tests were conducted in unstirred 160. $\mathrm{mI}$ carbon-stèel air-sealed containers (i.e., static systems). All vessels initially contained $100 \mathrm{~mL}$ of slurxy.

Additional slurries in concentrated salt solution, one containing only soluble metal and organic additives of Table A2 (no sludge nor MST solids present) and one containing all additives of Table A2 except MST, were tested at the higher temperatures of 55 and $70{ }^{\circ} \mathrm{C}$ (see V7-10 of Table AI). These tests were designed to provide information on the effects of solid additives on the extent of TPB reaction.

Single ( $\mathrm{K}, \mathrm{Na}$ ) TPB slurries in concentrated salt solution sample containing no potential soluble (metals or organics) nor solid (sludge or MST), additives shown in Table A2, i.e., 'control, samples', were included for comparison purposes at the two higher temperatures of 55 and $70{ }^{\circ} \mathrm{C}$ (see V11-12 in Table Al).

All containers were cleaned before testing by rinsing'with deionized water, contacting with $\sim 1 \%$ nitric acid for $\sim 1$ hr, rinsing with deionized water, heat treating to $\sim 580 .{ }^{\circ} \mathrm{C}$ for at least $8 \mathrm{hr}$, and lastly soaking in $0.5 \mathrm{M} \mathrm{NaOH}$ for at least $8 \mathrm{hr}$. 


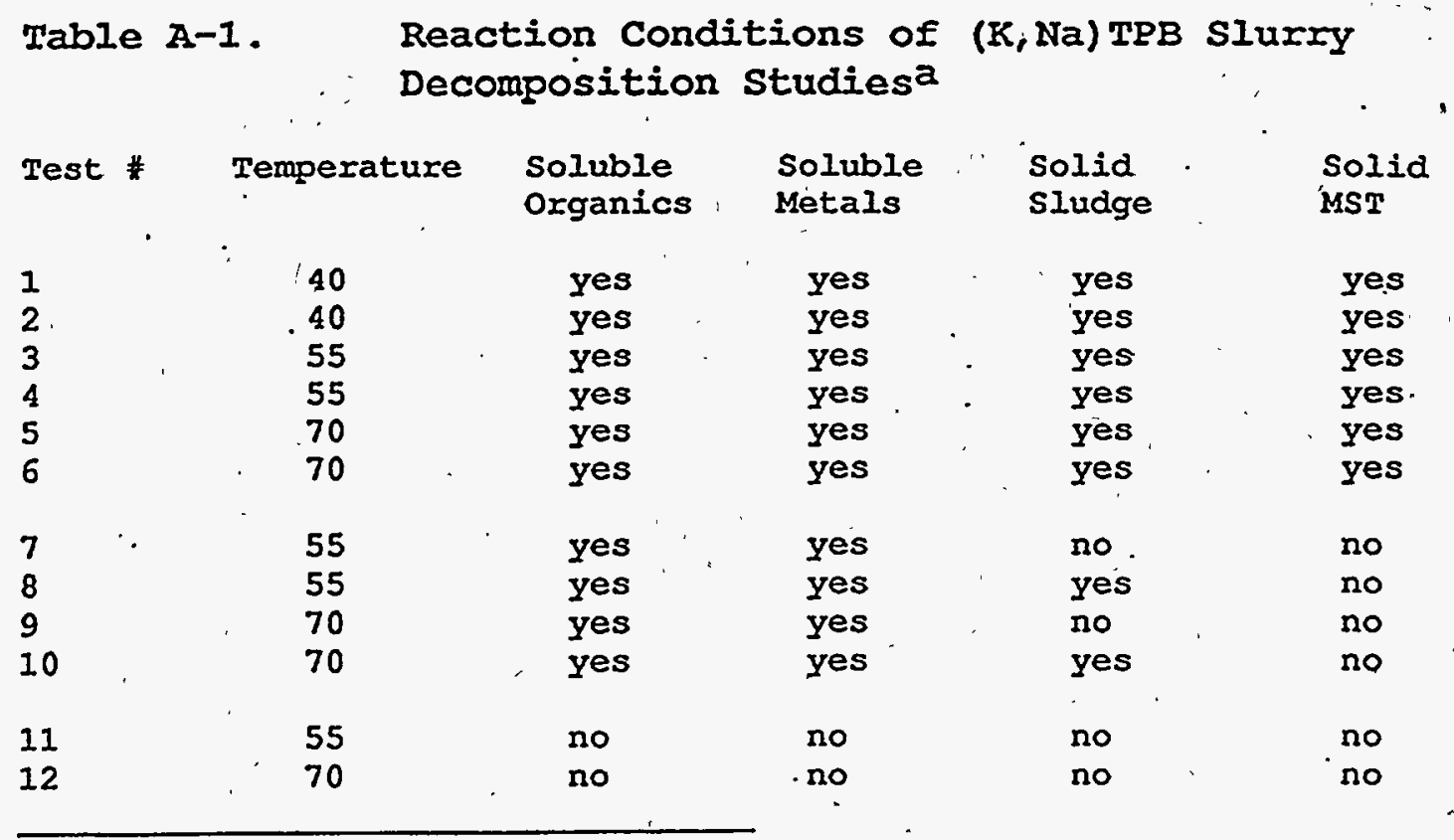

a All tețraphenylborate slurry prepared to be 5.5 wt 8 total (K, Na) TPB solids with 4.0 wt 8 KTPB (Or $48,000 \mathrm{mg} / \mathrm{I}$ KTPB), and 1.5 wt $\%$ NaTPB (or $18,000 \mathrm{mg} / \mathrm{I}$ NaTPB). 
Table A-2. Tank 48H Non-Radioactive Simulant Test Matrix for $(\mathrm{K}, \mathrm{Na})$ TPB Slurry Decomposition Studiesa

Salt Content

Soluble Metal Additives

(M)

-(mg/L)

Solid Additives

(wt oे)

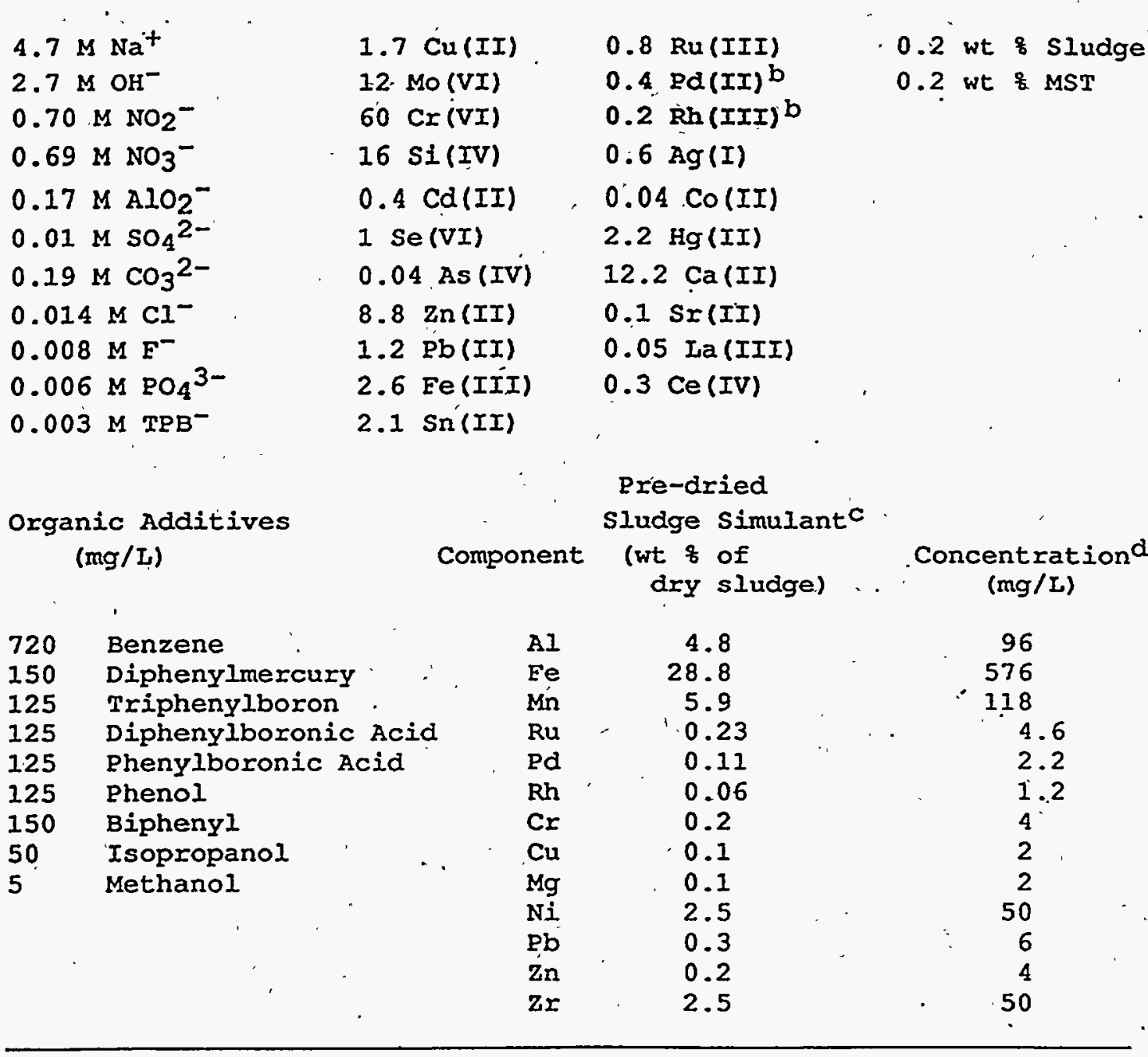

a Tetraphenylborate slurry prepared to be 5.5 wt o total (K,Na) TPB solids with 4.0 wt of KTPB (Or $48,000 \mathrm{mg} / \mathrm{L}$ KTPB) and 1.5 wt 8 NaTPB (or 1B,000 mg/L NáTPB):

b Palladium and rhodium soluble metal additives were not included as soluble additives in any of the previous TPB sealed-bottle catalyst tests reported in Ref. 1. Note that inclusion of these metal additives as soluble species in the present tests increases their magnitudes by:

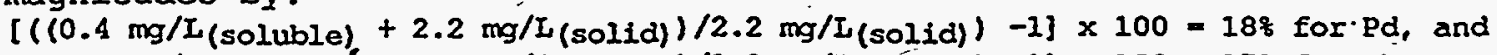

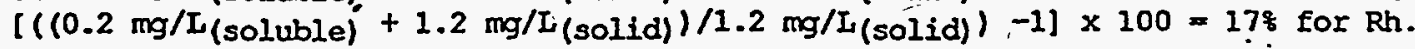

c'sludge composition originally reported in Ref. 1.

d These concentrations for sludge components based on presence of solid sludge at 0.2 wt $\frac{o}{6}$ in the simulated slurries. 
Samples from all slurries were analyzed to provide measurements of ' various components initially present. Subsequent sampling of the slurries was performed on a frequency of approximately every 2-3 days. All vessels were removed from the controlled tempexature environments and immersed in water baths to cool them to ambient temperature immediately before sampling. The slurries. were mixed by vigorous shaking irmediately prior to gas-phase and slurry sampling. 'All testvessels containing the slurry samples were weighed prior to and immediately after sampling.

A typical sampling extracted $\leq 0.5 \mathrm{cc}$ gas sample of the vapor-space within the sealed vessel and removed approximately $4 \mathrm{~mL}$ of slurry ( $1 \mathrm{~mL}$ analyzed for liquid benzene and $~ 3 \mathrm{~mL}$ filtered -- $0.45 \mu \mathrm{m}$ filter - - to provide filtrate for soluble organics, soluble boron, and possible soluble metal analyses). Ambient air, approximately equal to the gas or liquid amount withdrawn, was introduced into the sealed vessels immediately before each sampling. This was to prevent any depressurization of the sealed vessels due to multiple gas and slurry removals over the duration of the tests.

The experimental program to measure the decomposition of NaTPB in slurries used the following critical measurements.

Mass and volume Solutions were made from reagent grade chemicals by weighing on calibrated balances checked daily before use (WPTS Operating Procedure (WTT-OP-011). The weights used for balance checks were calibrated at the SRTC Standards Laboratory. Volume measurements were made with gilassware with accuracy verified by gravimetric methods using water as a standard (WPTS Operating Procedure IWT-OP-009):

Temperature' Samples were maintained at the specified testing temperatures by placement in laboratory ovens. Temperatures within the air-space of the ovens were determined by thermometers constantly kept in place within the ovens in very close proximity to the set of test vessels. Thermometers used were calibrated by SRTC Standards Laboratory using NIST-traceable procedures. The oven display temperature and thermometer temperatures were recorded on appropriate.data sheets located at each oven. These temperature data sheets were kept upon completion of the tests as a permanent record in laboratory notebooks. The frequency of temperature monitoring and control was adequate during normal daily laboratory hours to assure a constant thermometer. temperature reading within the range of $\pm 2{ }^{\circ} \mathrm{C}$ of the specified test temperature. Temperature monitoring and control during normal laboratory daily hours was conducted by researchers and technicians. Temperatures were also recorded on night-shift and weekend-shifts by SRTC Control Room personnel as requested by a 'night-sheet' records request that was officially filed with SRTC Control Room staff.

High-Performance figuid Chromatography (HPIC) Organic components were measured by HPLC methods from aqueous portions of the filtrate $10.45 \mu \mathrm{m}$ filter). These analyses were performed by the Analytical Development Section (ADS) of SRTC. ADS activities were controlled in accordance with the ADS QA program.14

Researchers used the following sample preparation and HPLC analysis. procedure: 15 
A $1 \mathrm{~mL}$ aliquot of each caustic solution to be analyzed was buffered with $\dot{2} .5 \mathrm{~mL}$ of potassium phosphate buffer solution, and then diluted to $10 \mathrm{~mL}$, with acetonitrile. The resulting mixture was mixed (inverted several times) for several minutes to facilitate the extraction of the organic components into the acetonitrile. Aliquots $(5-10 \mu \mathrm{L})$ of the organic-phase were then injected into two different HPLC units (HPLC and HPLC $\# 2$ ).

- HPLC *I (TPB-, 3PB and 2PB Analysis): TSP LC, acetonitrile-ammonium phosphate buffer eluent, Whatman ODS-2 column (TPB retention $=5.5$ minutes, $3 \mathrm{~PB}$ retention $\approx 11.5$ minutes, $2 \mathrm{~PB}$ retention $\approx 7.8$ minutes).

- HPLC *2, (1PB and Phenol Analysis): Hewlett Packard LC, acetonitrile-water eluent, Chemco-5-ODS column (1PB retention $\approx$ 10.5 minutes and phenol retention $=14.6$ minutes).

Benzene Measurements Benzene was measured by gas chromatography (GC). The GC instruments was calibrated for benzene with gravimetrically prepared standards from reagent grade bénzene (WPTS Operating Procedure \#IWT-OP-007). Both gas-phase (from within the sealed carbon-steel vessels) and liquid-phase (from small, $\leq 1-\mathrm{mL}$, aliquots of the mixed slurries) benzene were measured. Gas-phase benzene measurements were estimated by transferring a known volume of gas from within the sealed carbon-steel, vessels to a sealed secondary container (typically 20-60 mL glass vials) of known volume. Injections from the secondary container were made directly into the GC instrument.

Iiquid-phase benzene measurements were conducted by transfe'rring a 4-mL aliquot of the mixed slurry from the carbon steel vessels. Into a sealed secondaxy containet. This container was a 4-mL glass vial fitted with a screw-top lid. . The slurry was transferred in the $4-m L$ sealed glass vial to a separate laboratory containing the GC instrument. The $4 \mathrm{~mL}$ sluriy sample was then mixed by shaking, uncapped and sampled by transferring a small $\leq 1-m L$ portion via a calibrated micro-pipette to a sealed $1.0 \mathrm{I}$ glass bulb container. This bulb was agitated/swirled to ensure complete liquid 'coating' of the inner vessel walls to promote maximum liquid/vapor surface area within the bulb. From this sealed bulb a $\leq 0.250 \mathrm{cC}$ gas aliquot was injected into the GC for benzene analysis. AIl benzene measurements were typically performed within 4 to 8 hours of sluxry sampling.

Soluble Boren Species The filtrates of selected samples were analyzed for total soluble boron content to determine the extent of ( $K, N a)$ TPB solids (NaTPB and possibly KTPB solids) decomposition in the slurries. Total soluble boron was determined by. ICP-ES. All filtrates were diluted by a factor of six with deionized water. A single standard boron sample was submitted with each set of boron analyses. This multielement, high purity boron-containing standard contained boron at $\left(20 \mathrm{mg} / \mathrm{L} \pm 0.5 \%\right.$ ) in a $2 \% \mathrm{HNO}_{3}$ aqueous solution and was analyzed undiluted. The analyzed boron content for this standard was consistently biased high by about $15 \%$ laverage analysis from. 9 samples $=(23.1 \pm 1.8 \mathrm{mg} / \mathrm{L})$.

NaTPB Determination from Dissolution of Slurries An initial batch slurry and final test sample slurries were analyzed for solid NaTPB by mixing about 1 gram of well mixed slurry with $5 \mathrm{~mL}$ of deionized water. The 1-gram slurry samples were obtained from the 
slurries as they were being stirred (reacted slurries were transferred from the carbon steel reaction vessels into glass beakers) in attempts to obtain a representative sample. The, resulting diluted slurry, after being stored for about 24 hours unstirred, was filtered and analyzed for soluble TPB by HPLC analysis. These analyses were performed to measure both the initial (from the original batch slurry) and final amounts of solid NaTPB in the slurries. After review of the results from these tests, the analyses were repeated in duplicate for the batch slurry only, using a larger dilution volume of $40 \mathrm{~mL}$ deionized water and stirring of the diluted slurry for about 18 hours in a sealed container before filtration and HPLC analysis for TPB-.

Soluble Potassium

An initial batch slurry filtrate and all final test sample filtrates were analyzed for soluble potassium ion content using Atomic Absorption Spectroscopy to determine the extent of KTPB solubility in the aqueous phase of the slurries. These slurry samples were also obtained from the slurries as they were being stirred in attempts to obtain a representative sample. 
Amerine, D. B., $704-56 \mathrm{H}$

Barnes, M. J., 773-A

Britt; T. E., 730-2B

Byrd, D., 704-56H

Carter, J. T., 704-25S

Cauthen, G. L., 241-119H

Clark, W. C., 241-119H

. Crawford, C. L., 773-43A

Eberlein, S. J., 704-56H

Eibling, R., 704-T

Elder, H. H., 704-S

Fink, S. D., 773-A

Fowler, J. R., 241-121H

Griffin, J. C., 773-A

Hitchler, M. J., 730-2B

Holtzscheiter, E. W., 773-A

Hyder, M. L, 773-A

Jacobs, R. A., 704-T

Johnson, M. D., 704-56H

Keefer, M. T., 704-56H

Landon, L. F., 704-T

Lewis, B. L., 703-H

Lex, T. J., 719-4A

Marek, J. C., 704-T
McCabe, D. J., 773-43A

Menna, J. D., 241-119H

Miller, M. S., 704-56H

Montini, M. J., 704-56H

Morin, J. P., 719-4A .

Nash, C. A., 773-A

Nelson, L. M., 773-43A

Papouchado, L. M., 773-A

Peterson, R. A., 773-A

Rutland, P. L., 241-152H

Satterfield, R. M., 719-4A

Swingle, R. F., 773-A

Tamosaitis, W. L., 773-A

Taylor, G. A., 703-H

Van Pelt, W. B., 676-1T

Walker, D. D. 773-A

Wiggins, A. W., .241-152

Wilmarth, W. R., 773-A

Wooten, A. L., 732-B

Wright, G. T., 773-A

TIM, 703-43A

HLWE File Room,File Code 1.2.5.1, 703-H.

LWP Files, c/o A.-Patterson, 773-A

ITP Files/L. Sumner, 704-56H 